\title{
Editorial
}

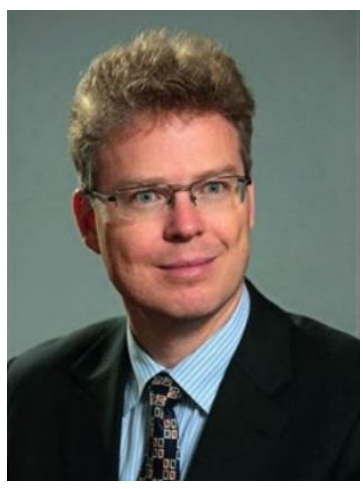

\section{Design of Biomethane Supply System Using Ecodesign Approach and System Dynamics Modelling}

\author{
Prof. Dr. Gatis Bazbauers
}

Institute of Energy Systems and Environment, Faculty of Power and Electrical

Engineering, Riga Technical University, Riga, Latvia

E-mail: gatis.bazbauers@rtu.lv

Biomethane can be produced from biogas by upgrading it to the quality of natural gas. This way it is possible to obtain a renewable substitute for natural gas, which may be injected into the natural gas grid and used in existing technologies without the need for replacement. Grid-supply of biomethane offers several important advantages. It allows substituting fossil for a renewable energy source in the technologies which require gaseous fuels, e.g. natural gas-fired industrial furnaces, gas engines and combined cycle gas turbine cogeneration plants. Biogas, after purification, can be diverted from distributed biogas-fired power plants, which often are relatively inefficient due to the lack of sufficient heat loads, to large district heating systems with efficient cogeneration possibilities. Biomethane supply via a natural gas grid would also facilitate maintenance and development of the natural gas supply infrastructure in future when consumption of natural gas may decline due to an increased share of renewable energy.

However, several important questions arise. First, is biomethane a sound choice from the environmental point of view in comparison with natural gas and potential renewable alternatives, e.g. biofuels, which also can be often used in natural gas-fired systems? Second, is biomethane an economically feasible alternative to natural gas? If not, what is the level of support required for production of biomethane to be put in price parity with natural gas? And finally, how should a support policy for a biomethane supply chain be designed to make it sustainable over time? These questions have been addressed in the research performed at the Institute of Energy Systems and Environment of Riga Technical University and the results have been published in several peer-reviewed papers.

In principle, the design of a biomethane supply system involves the system innovation from the ecodesign perspective since it allows improving environmental performance of the whole system currently using natural gas. Therefore, by following the ecodesign approach one should employ tools of environmental impact assessment, e.g. life cycle assessment (LCA), for the comparison of design alternatives from the environmental standing. This has been done by applying LCA to the case of brick production industry in Latvia and analysing "cradle-to-gate" environmental impacts per 1 ton of the product when the following fuels are used in the industrial furnace: natural gas, biomethane, and $1^{\text {st }}$ and $2^{\text {nd }}$ generation liquid biofuels. "ReCiPe" has been used as the environmental impact assessment method. The results show that the environmental impact could be reduced by circa $50 \%$ when biomethane is substituted for natural gas, and that biomethane and the $2^{\text {nd }}$ generation biofuel have roughly equal environmental impact as the $1^{\text {st }}$ generation biofuel, being far worse than even natural gas. Other studies based on life cycle inventory data have indicated that the use of biomethane instead of natural gas may reduce greenhouse gas emissions by nearly $80 \%$. The environmental benefits of fuel substitution, i.e. system innovation versus gradual improvements of natural gas-fired equipment efficiencies, can thus be clearly seen.

Development of a biomethane supply chain can be started by installation of upgrading facilities to the existing biogas plants and their connection to the natural gas grid. The study of the location of the biogas plants relative to the natural gas transmission pipelines has been done for Latvia using GIS. The results show that the average distance from the biogas plants to the natural gas transmission pipeline was circa $18 \mathrm{~km}$ with the shortest distances being less than $1 \mathrm{~km}$. In many places, the connection could be made to the natural gas distribution pipeline instead, thus, reducing the connection distance. Therefore, it can be claimed that in many places the connection of the biogas reactors to the grid may be feasible. The total costs of grid-injected biomethane produced would have to include capital, operation and maintenance costs of biogas production, upgrading and injection into the natural gas 
grid. The total costs have been calculated for 5 different biogas upgrading technologies and it has been found that the difference between the total biomethane production costs among these technologies was relatively small, i.e. approximately $3 \%$. The total costs can be reduced significantly, i.e. by circa $30 \%$, if biogas producers cooperate and build a single larger biogas production and upgrading facility instead of several of a smaller size. This indicates that the spatial distribution of biogas reactors and possibilities for cooperation among biogas producers to a large extent will determine competitiveness of grid-injected biomethane with natural gas. Currently, financial support is required for production of grid-injected biomethane since the minimum total costs of production achieved at the best scenario with 20 years of economic lifetime are nearly 50 EUR/MWh, exceeding the price of natural gas by approximately $16 \%$. For economic lifetime of 10 years, the difference is about $34 \%$. Therefore, we come to the need for the design of an appropriate support policy for the development of a biomethane supply system.

System dynamics modelling is a well-suited tool for the design of a renewable energy support policy since it allows analysing complex dynamic systems with feedbacks, delays and non-linearity. System dynamics has been successfully used at the Institute of Energy Systems and Environment for modelling of power and district heating supply systems, design of energy efficiency and waste management policies, analysis of the transport sector and sustainable energy supply systems. The challenge for energy policy makers lies in setting up the support system which leads to the perceived optimal growth of the renewable energy share and, for that reason, can be sustained over a long period of time. As experience shows, this is not a case in many countries, including Latvia, where support has led to the overshoot of the perceived limit of the financial support which can be carried by national economy, and it was corrected by a complete or nearly complete stall in the support. It is often noted that due to complexity of the energy supply system policy decisions for support of sustainability are difficult, i.e. it is difficult to foresee the dynamics of evolvement of the required support. Therefore, system dynamics has been chosen for creating the model which reveals the most crucial part in the support policy implementation, i.e. the structure of the policy system which leads to successful implementation of the support. Very few studies using system dynamics for the analysis of renewable energy policies have a focus on the structure of the support policy itself but rather look at the consequences in terms of the renewable energy share if the support is implemented or absent. The structure of the support policy for biomethane is built up by 2 parallel flows, i.e. the flow of granted permits to receive support, and the flow of actual investments into biomethane production facilities. Actual biomethane production is compared with the target value, which is based on the perceived limit of financial support at a certain period of time, and the feedback is taken back for adjusting dynamics of permit granting. This structure is similar to biological systems where a marginal increase of distribution of a certain plant in a limited territory decreases over time as space available for new plants shrinks. It is considered in the analysis of dynamics that not all permits will lead to actual investments and some will be cancelled after a certain period of time. This modelling approach allows comparison of several support alternatives, i.e. investment subsidies versus feed-in-tariff or feed-inpremium. Development of specific investments into technologies due to the learning effect and dynamics of a natural gas price are considered as well.

Combining life cycle assessment, GIS, technical and economic calculations with system dynamics modelling can be viewed as a method for system innovation leading from sound evaluation of alternatives to the actual policy for implementation of a particular system. This approach can be applied in the design of sustainable energy systems, waste management systems and other similar applications. 


\title{
Greywater Treatment with Simultaneous Generation of Energy Using Low-Cost Microbial Fuel Cells
}

\author{
K. J. Sajithkumar and E. V. Ramasamy \\ School of Environmental Sciences, Mahatma Gandhi University, Kottayam, Kerala, India \\ Corresponding author: \\ E. V. Ramasamy, School of Environmental Sciences, Mahatma Gandhi University, Kottayam, Kerala, 686560 , \\ India \\ E-mail: evramasamy@rediffmail.com
}

(received in July 2015; accepted in September 2015)

\begin{abstract}
Microbial fuel cells (MFCs) are an emerging type of biological wastewater treatment units with simultaneous power generation. The present study demonstrates an effective treatment of greywater and generation of electricity in a double-chambered MFC. This MFC was fabricated using costeffective and easily available materials replacing expensive materials like Nafion membranes, graphite electrodes, etc. Experimental results showed a maximum open circuit voltage of $0.64 \pm 0.04 \mathrm{~V}$ and $114 \pm 1.41 \mathrm{~mA}$ current during the study period. The results further indicate a maximum power generation of $24.50 \mathrm{~mW}$ along with $307.69 \mathrm{~mW} / \mathrm{m}^{2}$ of power density; $34.62 \mathrm{~mA} / \mathrm{m}^{2}$ of current density, $1.33 \mathrm{~W} / \mathrm{m}^{3}$ of volumetric power density, $0.15 \mathrm{~A} / \mathrm{m}^{3}$ of volumetric current density and a power yield of $0.40 \mathrm{~mW} / \mathrm{kg}$ of COD removal. The chemical oxygen demand (COD) removal efficiency was $77.6 \%$. The use of low-cost and easily available raw materials has brought down the total manufacturing cost of MFCs used in this study to less than USD 4.0. However, the performance of the MFCs used in the current study is comparable with other sophisticated MFCs built with expensive raw materials, as reported in the literature. This costeffective MFC used in the present study might be an effective replacement of expensive MFCs for wastewater treatment at scaled-up levels.
\end{abstract}

Keywords: greywater, microbial fuel cell (MFC), wastewater treatment, cost-effective, power output.

\section{Introduction}

A huge volume of wastewater is being discharged annually from domestic, industrial and agriculture sectors. Greywater is the wastewater exiting from households; excluding the wastewater from toilets and including bathrooms, bathtubs, showers, hand wash basins, laundry machines and kitchen sinks. In order to manage the alarming threat of drinking water scarcity in and around the world, there is an increasing demand in the treatment and reuse of greywater. About $75 \%$ of residential sewage fraction is greywater (Eriksson et al., 2002). As compared with black (toilet) water, greywater contains low concentrations of organic compounds, nutrients and pathogens (Otterpohl, 2002). Therefore, in order to manage the water scarceness, it makes sense to collect greywater separately and treat it for irrigation, washing or other non-potable applications. It should be treated properly to meet the discharge standards prior to their release into the environment (Suzuki et al.; 2002, Maekawaet al., 1995).

Many treatment techniques have been proposed for the removal of inorganic and organic pollutants from wastewater. Most of these processes entail high operational costs or large areas of land for treatment (Min et al., 2005). In this scenario, high energy requirements of conventional sewage treatment systems demand an alternative treatment technology, which will be cost-effective and require no or less energy. Anaerobic technologies have been finding increasing application in the past few decades in the treatment of domestic and industrial wastewater with dual benefit of wastewater treatment as well as energy production in terms of methane-rich biogas. Process instability and microbial flush-out are the main 
drawbacks of anaerobic reactors, particularly in a small-scale biogas plant (Gangrekar \& Shinde, 2006). An alternative technique emerging more recently for wastewater treatment and energy production is microbial fuel cells (MFCs). In MFCs, electricity can be produced with simultaneous degradation of organic matter by microorganisms. MFCs are generally fabricated into 2 chambers: one is anode chamber, while the other is cathode chamber. The cathode chamber is maintained with anaerobic conditions and the organic material given as a substrate will be oxidised by the anaerobic microorganisms; the electrons lost in the process are transferred to the anode by either an electron carrier (mediator) added in the MFC or directly from the respiratory enzyme of the microbes (mediator less) (Logan et al., 2007)

From the literature survey, it can be noted that extensive research on microbial fuel cells is going on on a laboratory scale and most of such studies have been using double or single chamber MFCs with expensive raw materials including Nafion-based proton exchange membranes (Logan et al., 2007; Venkata Mohan et al., 2008; Greenman et al., 2009; Wen et al., 2009; Sangeetha et al., 2011). The generation of electricity using MFCs with different substrates has also been reported. In most of the MFCs, pure compounds such as acetate (Bond \& Lovely, 2003), glucose (Rabaey et al., 2003), sucrose (He et al., 2006), amino acid (cysteine; Logan et al., 2005), and proteins (bovine serum albumin) (Heilmann \& Logan, 2006) are used as substrates. Wastewater from various industries, such as swine (Min et al., 2005), meat packing (Heilmann \& Logan, 2006), food processing (Kim et al., 2004), beer brewery, paper (Mathuriya \& Sharma, 2009a, 2009b), corn stover hydrolysates (liquefied corn stover) (Zuo et al., 2006), food processing industries (Sangeetha et $a l ., 2011$ ), and wastewater from domestic activities (Liu et al., 2004) have also been treated using MFCs. Most of the previous studies have reported that MFCs operated with wastewater generate a lower amount of energy than those operated with pure compounds.

Greywater, even though it is a good source of organic matter, has not been reported so far as a substrate in MFCs. Hence, in the present study, greywater was used as a substrate in doublechambered MFCs. Double-chambered MFCs have been successfully operated by many researchers for the simultaneous generation of electricity and wastewater treatment (Min et al., 2005; Raghavulu et al., 2009; Jadhav \& Ghangrekar, 2009; Sangeetha et al., 2011) with expensive raw materials, such as graphite electrodes and Nafion-based proton exchange membranes. Hence, the development of MFCs with cost-effective raw materials is a thrust area of research in MFC studies. In this context, the major objective of the present study is to develop laboratory-scale MFCs with cost-effective materials and use them in greywater treatment. The performance of doublechambered MFCs treating greywater was assessed in terms of electricity production, removal of chemical oxygen demand (COD removal) and total solids (TS).

\section{Materials and methods \\ $2.1 \quad$ Substrates used}

Greywater was collected from the student's hostel of Mahatma Gandhi University and stored under the refrigeration at $4^{\circ} \mathrm{C}$ before use. After analysing the characteristics (Table 1), greywater was used as the substrate for MFC without any modifications, such as $\mathrm{pH}$ adjustment or the addition of nutrients/trace metals. The experiments were conducted using full-strength wastewater.

\subsection{Microbial fuel cells}

The whole experiment was designed with 2 double-chambered MFCs, which were fabricated with salt bridges as described by Mohan et al., (2008) and Min et al., (2005). Two polyethylene terephthalate (PET) bottles of $400 \mathrm{~mL}$ capacity were used as 2 chambers of each MFC. One bottle was used as the anode chamber and maintained under anaerobic conditions. The other bottle was used as the cathode chamber, maintained aerobic by providing an external air supply with a sparger network (Mohan et al., 2007). Carbon brushes were used as electrodes in each chamber. The electrodes were kept $10 \mathrm{~cm}$ apart from each other and were externally connected through copper wires after sealing the contact area with epoxy resin. The chambers were provided with inlet and outlet ports. Both the anode and cathode chambers were connected through a salt bridge of $8.5 \mathrm{~cm}$ length and $1.1 \mathrm{~cm}$ inner diameter, prepared by using $\mathrm{KCl}$ solution and agar-agar.

\subsection{Experimental methods. MFC operation}

MFC operation was started by filling the anode chamber with $250 \mathrm{~mL}$ of greywater (substrate) and $50 \mathrm{~mL}$ of digested effluent from an ongoing anaerobic reactor as inocula. In all MFCs, the cathode chamber was kept in aerobic conditions with $\mathrm{KCl}$ solution $(300 \mathrm{~mL})$ as catholyte and was replenished once in a week as it got denatured. Initially, the MFCs were operated in the batch mode for 10 days, i.e. without further addition of the substrate during this period. This is to facilitate the acclimatisation of microbes with the substrate. After 10 days of the batch mode, both MFCs were operated semi-continuously for a total period of 30 days with 6 cycles of feeding at an interval of 5 days each. On each cycle, daily feeding of $50 \mathrm{~mL}$ of the substrate was carried out and, thus, at the end of each cycle, a total of $250 \mathrm{~mL}$ substrate was treated. The total experimental period including the batch mode of operation was 40 days. Daily monitoring of voltage and current was carried out during the study period, with different loads of resistance using a digital multimeter. Periodic assessment of greywater treatment in MFCs was done in terms of COD and total solids removal.

Total (dry) solids, volatile solids and chemical oxygen demand (COD) of the influent and the effluent of the MFCs were determined as per standard methods of APHA (1995). Power (W) was calculated using the 
relation $\mathrm{P}=\mathrm{v}^{2} / \mathrm{R}$ external, where $\mathrm{v}$ represent voltage $(\mathrm{V})$ and $\mathrm{R}$ is the external resistance load. Power density $\left(\mathrm{mW} / \mathrm{m}^{2}\right)$ and current density $\left(\mathrm{mA} / \mathrm{m}^{2}\right)$ were calculated by dividing the obtained power and current by the anode surface area $\left(\mathrm{m}^{2}\right)$. Power yield $(\mathrm{W} / \mathrm{kg}$ COD removal) was obtained by dividing power with corresponding substrate (COD) removal values. Volumetric power $\left(\mathrm{W} / \mathrm{m}^{3}\right)$ and current density $\left(\mathrm{A} / \mathrm{m}^{3}\right)$ were calculated based on the anode liquid volume (Venkata Mohan et al., 2007).

\section{Results and discussion}

The characteristics of greywater used in the study was analysed and the results are presented in Table 1. Daily monitoring of voltage and current was carried out during the study period, with different loads of resistance using a digital multimeter. Each measurement lasted for 3 minutes at each resistance and concordant values. The results were presented as average of MFCs calculated to evaluate the performance of respective duplicate cells of MFCs.

Table 1. Characteristics of greywater used as substrate in MFC.

\begin{tabular}{|c|c|c|c|c|c|c||}
\hline \hline \multirow{2}{*}{ Parameters } & \multicolumn{7}{|c|}{ Characteristics } \\
\cline { 2 - 8 } & $1^{\text {st }}$ cycle & $2^{\text {nd }}$ cycle & 3 rd cycle & $4^{\text {th }}$ cycle & $5^{\text {th }}$ cycle & $6^{\text {th }}$ cycle \\
\hline $\mathrm{pH}$ & 6.30 & 6.52 & 6.45 & 6.25 & 6.20 & 6.14 \\
\hline Total Solids (mg/L) & 1,915 & 1,910 & 2,440 & 2,555 & 2,030 & 1,900 \\
\hline Nitrate $(\mathrm{mg} / \mathrm{L})$ & 6.50 & 6.81 & 7.13 & 7.77 & 7.43 & 7.89 \\
\hline Sulphate $(\mathrm{mg} / \mathrm{L})$ & 15.85 & 15.67 & 16.47 & 15.69 & 15.15 & 16.33 \\
\hline Phosphate (mg/L) & 22.69 & 23.71 & 24.25 & 24.16 & 22.80 & 23.69 \\
\hline Chemical Oxygen Demand (mg/L) & 1,382 & 1,396 & 1,402 & 1,402 & 1,384 & 1,400 \\
\hline \hline
\end{tabular}

Results in terms of electricity generation from wastewater

After inoculation and feeding, a slow increase in the current was observed in all MFCs. After 10 days of acclimatisation of the microbes with the substrate, a steady current was observed as output in MFCs. The development of microbial population in the form of biofilm has been found to occur between 6 to 15 days until a stable current generation was obtained (Liu et $a l ., 2005)$. In the present study, the open circuit voltage (OCV) was also observed as a steady output after 10 days of operation. OCV is the cell voltage between 2 terminals of a device when disconnected from any circuit. The maximum OCV of $0.64 \pm 0.04 \mathrm{~V}$ and $114 \pm 1.4 \mathrm{~mA}$ of the current were recorded on day 36 (Figure 1). From the figure, it is clear that the potential of the MFC increases as the number of days increases. The results obtained in the present study are comparable with those of Dalvi et al. (2011), who conducted a study on electricity generation with paneer whey degradation with different microorganisms in a dual-chambered MFC and the results showed an OCV of $0.45 \mathrm{~V}$.

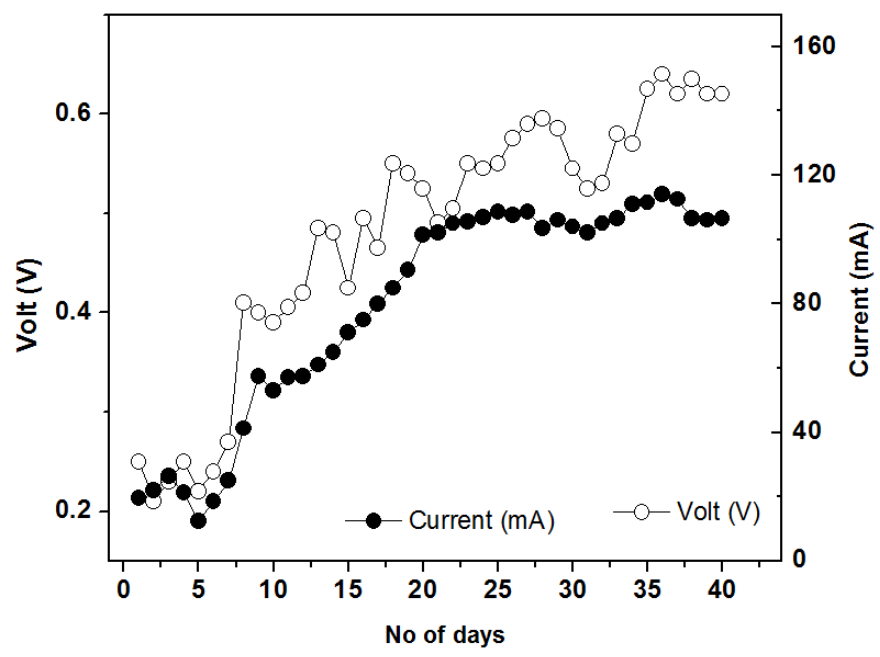

Figure 1. Open circuit voltage and current of MFC treating greywater.

Even though the performance of an MFC can be evaluated in many ways, it is principally done with power output. The power output is usually normalised to the projected anode surface area, where most of the biological activity occurs. In the present study, the power production in MFCs reached the maximum of $24.50 \mathrm{~mW}$ on day 36 (Figure 2). It may be noted that the power output showed increments after each feeding of MFCs, indicating multiplication of microbes and their acclimatisation to the new microenvironment. A gradual rise in power was observed after every fresh feed addition, which indicates that the attached microbes on the anode as biofilm contributed to the electricity generation rather than the suspended ones. Sangeetha \& Muthukumar (2012) in their study on using sago wastewater have reported $8.1 \mathrm{~mW}$ power using graphite as electrode on day 17 of the experiment. Their results also supported the view that the power output showed increments after each feeding. 


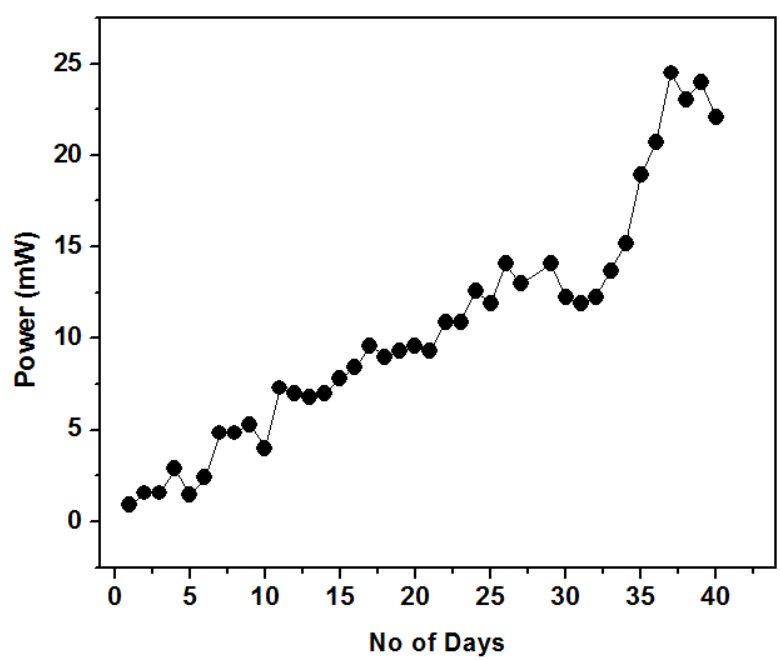

Figure 2. Power generation graph of MFC treating greywater.

Table 2 shows the power generation details of MFCs. At the continuous external load of $100 \Omega$ resistances, the maximum power density of $307.69 \mathrm{~mW} / \mathrm{m}^{2}$, current density of $34.62 \mathrm{~mA} / \mathrm{m}^{2}$, volumetric power density of $1.33 \mathrm{~W} / \mathrm{m}^{3}$, and volumetric current density of $0.15 \mathrm{~A} / \mathrm{m}^{3}$ were recorded.

Table 2. Average power generation details of MFCs at $100 \Omega$ resistances.

\begin{tabular}{|c|c|c|c|c|}
\hline $\begin{array}{l}\text { No of } \\
\text { Days }\end{array}$ & $\begin{array}{c}\text { Power density } \\
\mathrm{mW} / \mathrm{m}^{2}\end{array}$ & $\begin{array}{c}\text { Volumetric power density } \\
\mathrm{W} / \mathrm{m}^{3}\end{array}$ & $\begin{array}{c}\text { Current density } \\
\mathrm{mA} / \mathbf{m}^{2}\end{array}$ & $\begin{array}{c}\text { Volumetric current } \\
\text { density } \mathrm{A} / \mathbf{m}^{3}\end{array}$ \\
\hline 1-10 days* & $0.275 \pm 0.123$ & $0.001 \pm 0.001$ & $1.231 \pm 0.649$ & $0.005 \pm 0.003$ \\
\hline 11 & 0.62 & 0.0027 & 3.0769 & 0.0133 \\
\hline 12 & 0.77 & 0.0033 & 3.8462 & 0.0167 \\
\hline 13 & 0.77 & 0.0033 & 3.8462 & 0.0167 \\
\hline 14 & 3.08 & 0.0133 & 4.6154 & 0.0200 \\
\hline 15 & 4.81 & 0.0208 & 6.1538 & 0.0267 \\
\hline 16 & 6.92 & 0.0300 & 6.9231 & 0.0300 \\
\hline 17 & 12.31 & 0.0533 & 6.1538 & 0.0267 \\
\hline 18 & 19.23 & 0.0833 & 7.6923 & 0.0333 \\
\hline 19 & 43.27 & 0.1875 & 7.6923 & 0.0333 \\
\hline 20 & 23.27 & 0.1008 & 15.38462 & 0.0667 \\
\hline 21 & 27.69 & 0.1200 & 15.38462 & 0.0667 \\
\hline 22 & 43.27 & 0.1875 & 21.53846 & 0.0933 \\
\hline 23 & 43.27 & 0.1875 & 22.30769 & 0.0967 \\
\hline 24 & 37.69 & 0.1633 & 14.61538 & 0.0633 \\
\hline 25 & 49.23 & 0.2133 & 34.61538 & 0.1500 \\
\hline 26 & 49.23 & 0.2133 & 22.30769 & 0.0967 \\
\hline 27 & 43.27 & 0.1875 & 27.69231 & 0.1200 \\
\hline 28 & 49.23 & 0.2133 & 22.30769 & 0.0967 \\
\hline 29 & 55.58 & 0.2408 & 29.23077 & 0.1267 \\
\hline 30 & 55.58 & 0.2408 & 20.76923 & 0.0900 \\
\hline 31 & 49.23 & 0.2133 & 15.38462 & 0.0667 \\
\hline 32 & 49.23 & 0.2133 & 15.38462 & 0.0667 \\
\hline 33 & 62.31 & 0.2700 & 21.53846 & 0.0933 \\
\hline 34 & 76.92 & 0.3333 & 22.30769 & 0.0967 \\
\hline 35 & 69.42 & 0.3008 & 14.61538 & 0.0633 \\
\hline 36 & 173.08 & 0.7500 & 34.61538 & 0.1500 \\
\hline 37 & 173.08 & 0.7500 & 22.30769 & 0.0967 \\
\hline 38 & 307.69 & 1.3333 & 27.69231 & 0.1200 \\
\hline 39 & 235.58 & 1.0208 & 29.23077 & 0.1267 \\
\hline 40 & 76.92 & 0.3333 & 20.76923 & 0.0900 \\
\hline
\end{tabular}

*1-10 days - the batch mode of operation was carried out, and the average values of the results are presented.

Lu et al. (2009) operated an MFC with starch processing wastewater containing $4,900 \mathrm{mg} / \mathrm{L}$ of COD over 4 cycles and obtained the maximum power density of $239.4 \mathrm{~mW} / \mathrm{m}^{2}$ in the third cycle. Similar results were also reported by Sangeetha et al., (2011) with food processing wastewater. The distance between cathode and anode plays an important role in power generation of fuel cells. As the distance between the 2 electrodes is less, the resulting power output will be high by dropping the ohmic resistance 
(Jang et al., 2004). In the present study, the electrodes of MFCs were kept at a distance of $10 \mathrm{~cm}$ resulting in good power output (Figure 2). The effect of electrode distance on MFC performance was carried out by Sangeetha \& Muthukumar (2012) varying it as $10 \mathrm{~cm}$, $12 \mathrm{~cm}$ and $15 \mathrm{~cm}$. Their study revealed that electrode distance of $10 \mathrm{~cm}$ resulted in increased power production with a voltage of $900 \mathrm{mV}$ (millivolts), current of $9.0 \mathrm{~mA}$ (milliamps) at $100 \Omega$ resistances and COD removal of $94 \%$. A similar trend of an increase in MFC performance with a decreasing distance between the electrodes was observed by Liu et al. (2005), Kim et al. (2007), Ghangrekar \& Shinde (2007), and Cheng et al. (2006).

Effect of organic loading rate on power generation.

The amount of electricity produced from wastewater depends upon COD loading (Oh and
Logan, 2005). The present study showed greater power output with high COD loading. Wastewater from various sources with a COD ranging $1,000-10,000 \mathrm{mg} / \mathrm{L}$ is a potential substrate for MFCs (Pant et al., 2009). Greywater used in the present study had an average COD value of $1394.33 \pm 9.04 \mathrm{mg} / \mathrm{L}$. The overall COD removal efficiency observed in the present study was $71.36 \pm 1.93 \%$, demonstrating the feasibility of this configuration of MFCs as an effective wastewater treatment system, also ensuring better effluent quality. The organic matter present in greywater at the anode chamber was effectively consumed by microorganisms resulting in COD removal from greywater (Figure 3). Power yield of MFCs with respect to daily COD removal was calculated and shown in Figure 4. In accordance with the COD reduction results, MFCs showed a power yield of $0.40 \mathrm{~mW} / \mathrm{kg}$ COD removal.

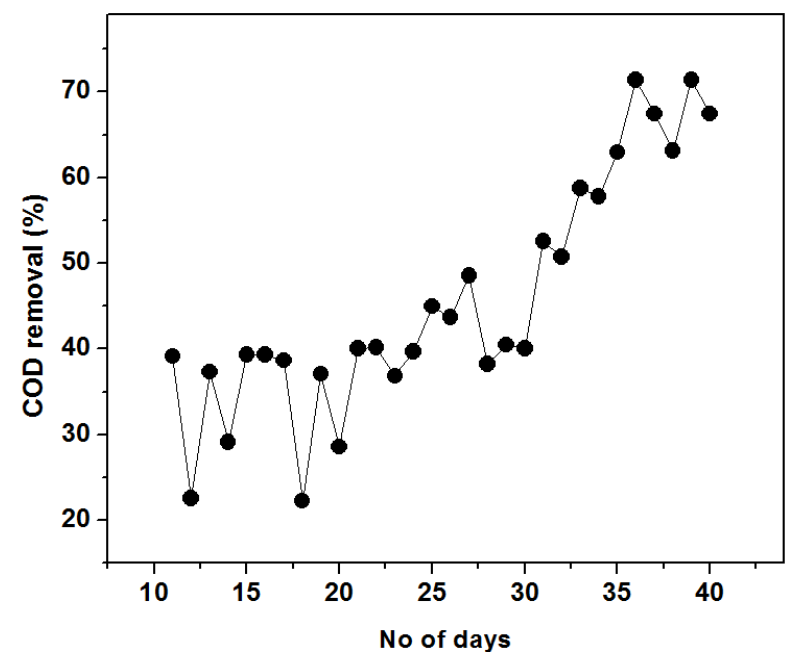

Figure 3. Results in terms of percentage COD removal.

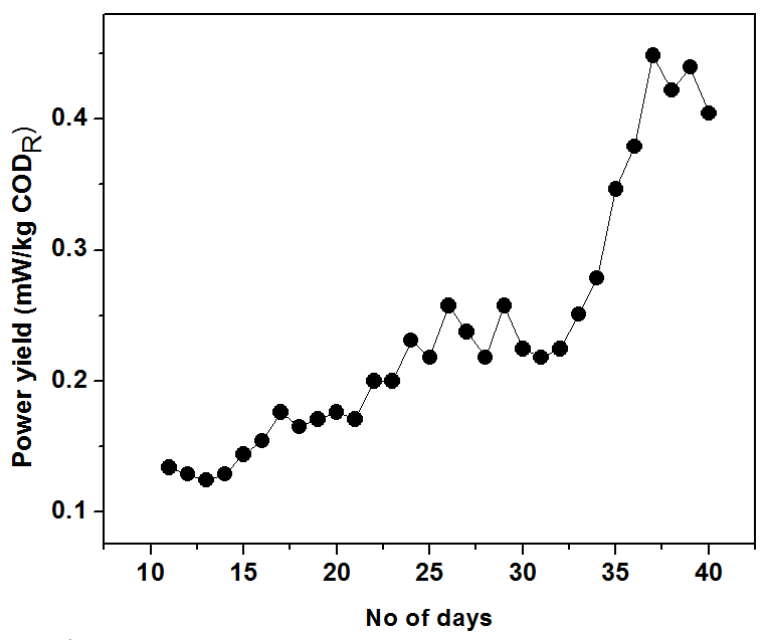

Figure 4. Power yield of MFC treating greywater.

The solid removal efficiency of MFCs was also analysed and the results are shown in Figure 5. During the study period, the effluent samples from both MFCs showed a gradual decrease in the concentration of total and volatile solids due to the microbial action. 


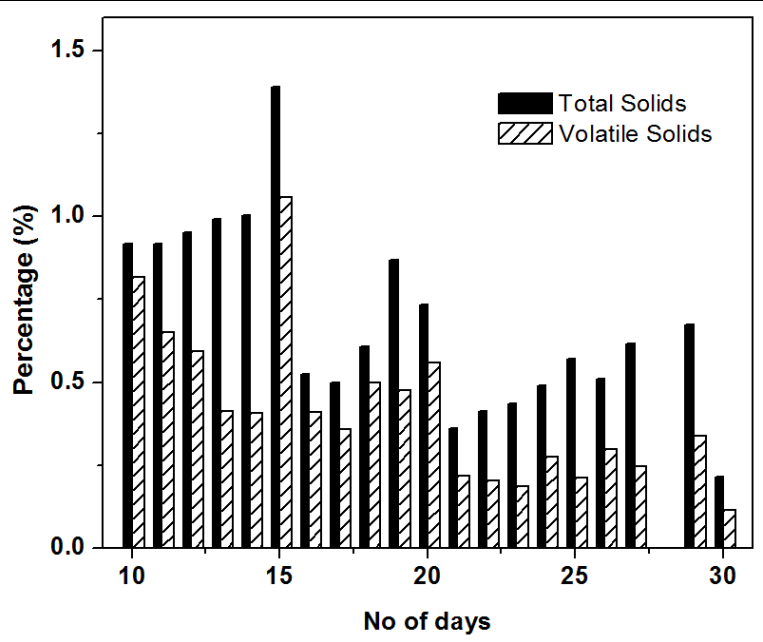

Figure 5. Total and volatile solid concentration in the effluent from MFCs.

\section{Conclusions}

The efficiency of MFCs used for the treatment of greywater was successfully evaluated in the present study with remarkable results of electricity production and COD removals. One of the major drawbacks of conventional MFCs, which utilize graphite electrodes and Nafion-based proton exchange membranes, is high cost. The significance of the present study is the cost effectiveness of the raw materials used for the fabrication of MFCs. In the present study, in order to transfer protons to the cathode, a salt bridge and carbon brushes were used as electrodes, which are less expensive and easily available. This low-cost MFC, with the manufacturing cost of less than USD 4.0, has performed with comparable performance on a par with many sophisticated MFCs employing expensive proton exchange membranes. The low-cost MFCs used in the present study may be an effective alternative for an expensive Nafion-based MFC in wastewater treatment at scaled-up levels. However, the lower electrode potential of the present MFC has to be improved by decreasing its internal resistance. Further studies are presently going on towards improving the performance of the cathode with less internal resistance using low-cost raw materials.

\section{Acknowledgements}

The financial support from the Department of Environment and Climate Change (DoECC), Government of Kerala through 'Paristhithiposhini' fellowship programme is gratefully acknowledged. The authors also gratefully acknowledge the support from DST-PURSE and DST-FIST, Government of India.

\section{References}

APHA (American Public Health association) (1995). Standard methods for examination of water and wastewater, 19th edition. APHA, Washington DC, USA.

Behera, M., Jana, P. S., \& Ghangrekar, M. M. (2010). Performance evaluation of low cost microbial fuel cell fabricated using earthen pot with biotic and abiotic cathode. Bioresource technology, 101(4), 1183-1189. http://dx.doi.org/10.1016/j.biortech.2009.07.089

Bond, D. R. \& Lovley, D. R. (2003). Electricity production by Geobactersulfurreducensattached to electrodes. Applied and Environmental Microbiology, 69(3),15481555. http://dx.doi.org/10.1128/AEM.69.3.1548-1555.2003

Dalvi, A. D., Mohandas, N., Shinde, O. A., \& Kininge, P. T. (2011). Microbial fuel cell for production of bioelectricity from whey and biological waste treatment. International Journal of Advanced Biotechnology and Research, 2(2), 263-268.

Eriksson, E., Auffarath, K., Henze, M., \& Ledin, A. (2002). Characteristics of grey wastewater. Urban water, 4,85 104. http://dx.doi.org/10.1016/S1462-0758(01)00064-4

Ghangrekar, M. M. \& Shinde, V. B. (2006). Microbial fuel cell: a new approach of wastewater treatment with power generation. In: International Workshop on R\&D Frontiers in Water and Wastewater Management. Nagpur, India, pp. 20-21.

He, Z., Wagner, N., \& Minteer, S. D. (2006). An up flow microbial fuel cell with an internal resistance by impedance spectroscopy. Environmental Science and Technology, 40, 5212-5217. http://dx.doi.org/10.1021/es060394f

Heilmann, J. \& Logan, B. E. (2006). Production of electricity from proteins using a single chamber microbial fuel cell. Water Environment Research, 78(5), 531-537. http://dx.doi.org/10.2175/106143005X73046

Jadhav, G. S. \& Ghangrekar, M. M. (2009).Performance of microbial fuel cell subjected to variation in $\mathrm{pH}$, temperature, external load, and substrate concentration. Bioresource Technology, 100, 717-723. http://dx.doi.org/10.1016/j.biortech.2008.07.041

Jadhav, G. S., Jagtap, Y. D., \& Ghangrekar, M. M. (2013). Dual-chambered membrane microbial fuel cell: limitation on potential difference. International Journal of Engineering Research and Technology, 2(4). 
Liu, H. \& Logan, B. E. (2004). Electricity generation using an air-cathode single chamber microbial fuel cell in the presence and absence of a proton exchange membrane. Environmental Science and Technology, 38(14), 40404046. http://dx.doi.org/10.1021/es0499344

Liu, H., Ramnarayanan, R., \& Logan, B. E (2004). Production of electricity during wastewater treatment using a single chamber microbial fuel cell. Environmental Science and Technology. 38:2281-2285. http://dx.doi.org/10.1021/es034923g

Logan, B. E., Hamelers, B., Rozendal, R., Schröder, U., Keller, J., Freguia, S., \& Rabaey, K. (2006). Microbial fuel cells: methodology and technology. Environmental science \& technology, 40(17), 5181-5192. http://dx.doi.org/10.1021/es0605016

Lu, N., Zhou, S., Zhuang, L., Zhanag, J. T., Ni J. R. (2009). Electricity generation from starch processing wastewater using microbial fuel technology. Biochemical engineering journal, 43, 246-251. http://dx.doi.org/10.1016/j.bej.2008.10.005

Maekawa, T., Liao, C. M., \& Feng, X., D. (1995). Nitrogen and phosphorus removal for swine wastewater using intermittent aeration batch reactor followed by ammonium crystallization process. Water Research, 29(12), 2643-2650. http://dx.doi.org/10.1016/0043-1354(95)00153-C

Min, B., Cheng, S., \& Logan, B. E. (2005). Electricity generation using membrane and salt bridge microbial fuel cells. Water research, 39(9), 1675-1686. http://dx.doi.org/10.1016/j.watres.2005.02.002

Otterpohi, R. (2002). Options for alternative types of sewerage and treatment systems directed to improvement of the overall performance. Water science and technology, 45(3), 149-158.

Pant, D., Van Bogaert, G., Diels, L., \& Vanbroekhoven, K. (2009). A review of the substrates used in microbial fuel cells (MFCs) for sustainable energy production. Bioresource Technology, 101(6), 1533-1543

Rabaey, K., Lissens, G., \& Siciliano, S. D. (2003). A microbial fuel cell capable of converting glucose to electricity at high rate and efficiency. Biotechnology Letters, 25(18), 1531-1535 http://dx.doi.org/10.1023/A:1025484009367

Raghavulu, S. V., Mohan, S. V., Goud, R. K., \& Sarma, P. N. (2009). Effect of anodic pH microenvironment on microbial fuel cell (MFC) performance in concurrence with aerated and ferricyanidecatholytes. Electrochemistry Communications, 11, 371-375 http://dx.doi.org/10.1016/j.elecom.2008.11.038

Rodrigo, M. A., Canizares, P., Lobato, J., Paz, R., Sáez, C., \& Linares, J. J. (2007). Production of electricity from the treatment of urban waste water using a microbial fuel cell. Journal of Power Sources, 169(1), 198-204. http://dx.doi.org/10.1016/j.jpowsour.2007.01.054

Sangeetha, T. \& Muthukumar, M. (2011). Catholyte performance as an influencing factor on electricity production in a dual chambered microbial fuel cell employing food processing wastewater. Energy Sources, Part A, 33, 1514-1522.

Suzuki, K., Tanaka, Y., Osada, T., \& Waki, M. (2002). Removal of phosphate, magnesium and calcium from swine wastewater through crystallization enhanced by aeration. Water Research, 36(12), 2991-2998. http://dx.doi.org/10.1016/S0043-1354(01)00536-X

Zuo, Y., Maness, P. C., \& Logan, B. E (2006). Electricity production from steam-exploded corn stover biomass. Energy Fuels, 20(4), 1716-1721 http://dx.doi.org/10.1021/ef0600331 


\title{
Pilkojo vandens valymas ir elektros energijos generavimas, naudojant nebrangius mikrobinius kuro elementus
}

\author{
K. J. Sajithkumar ir E. V. Ramasamy \\ Aplinkosaugos mokslu fakultetas, Mahatma Gandhi Universitetas, Kottayam, Kerala, Indija
}

(gauta 2015 m. liepos mèn.; priimta spaudai 2015 m. rugsèjo mèn.)

\begin{abstract}
Mikrobiniai kuro elementai (angl. microbial fuel cells - MFCs) - tai besivystantys biologinio nuotekų tvarkymo technologija, kuri tuo pačiu metu generuoja elektros energiją. Šis tyrimas pristato efektyvu pilkojo vandens valymą kartu su elektros energijos gamyba dvigubos kameros MFCs. MFCs buvo pagaminti naudojant rentabilias ir lengvai prieinamas medžiagas, pakeičiant tokius brangius metalus, kaip Nafion membranos, grafito elektrodai ir pan. Eksperimentiniai rezultatai parodè, kad tyrimo metu didžiausia atviros elektros srovès įtampa siekè $0,64 \pm 0,04 \mathrm{~V}$, o srovès stipris $114 \pm 1,41 \mathrm{~mA}$. Rezultatai taip pat parode, kad išvystyta galia siekè $24,5 \mathrm{~mW}$, kai galios tankis buvo $307,69 \mathrm{~mW} / \mathrm{m}^{2}$; srovès stiprio tankis $34,62 \mathrm{~mA} / \mathrm{m}^{2}$, galios tūrinis tankis $1,33 \mathrm{~W} / \mathrm{m}^{3}$, srovès stiprio tūrinis tankis $0.15 \mathrm{~A} / \mathrm{m}^{3}$ ir galios išeiga $0,40 \mathrm{~mW} / \mathrm{kg}$ cheminio deguonies suvartojimo (ChDS) panaikinimui. ChDS pašalinimo efektyvumas sieke 77,6\%. Nebrangių ir lengvai prieinamy žaliavų naudojimas leido sumažinti šiame tyrime naudotų MFCs bendrus gamybos kaštus iki mažiau nei 4,0 JAV dolerių. Nepaistant to, šiame tyrime naudotų MFCs rezultatai gali būti sulyginami su kitais sudètingais MFCs, kurie yra sukurti naudojant brangias žaliavas, pateiktas literatūroje. Šie rentabilūs tyrime naudojami MFCs gali būti efektyvus pakaitalas brangiems MFCs, kurie naudojami nuotekoms valyti aukštesniuose lygiuose.

Raktiniai žodžiai: pilkasis vanduo, mikrobinis kuro elementas, nuoteku valymas, rentabili galios išeiga.
\end{abstract}




\title{
Assessment of Metal Pollution of Soil and Diagnostic Species Associated with Oil Spills in the Niger Delta, Nigeria
}

\author{
Paul O. Fatoba, Clement O. Ogunkunle, and Cynthian O. Ihaza \\ Environmental Biology Unit, Department of Plant Biology, University of Ilorin, Nigeria \\ Corresponding author: \\ Clement O. Ogunkunle, Environmental Biology Unit, Department of Plant Biology, P. M. B. 1515, University of \\ Ilorin, 240003 Nigeria \\ E-mail:seyeogunkunle@gmail.com (ogunkunle.co@unilorin.edu.ng)
}

(received in June 2015; accepted in July 2015)

\begin{abstract}
An ecological impact assessment of crude-oil spills was carried out on the environment of an oil-rich community in the Niger Delta of Nigeria. Samples of the topsoil $(0-15 \mathrm{~cm})$, subsoil $(15-25 \mathrm{~cm})$ and the dominant species Gamba grass (Andropogon gayanus) were collected using the transect method from the point of spills. The samples were also collected from an unimpacted location (control). The samples were wet-digested and the concentrations of $\mathrm{Pb}, \mathrm{Cd}, \mathrm{Cu}$, and $\mathrm{Zn}$ were determined by flame atomic absorption spectrophotometry, while the physico-chemical properties of the topsoil were determined by standard methods. The data were subjected to Student $t$ test, ANOVA and Pearson correlation analysis, and the models for pollution assessment were employed to assess the pollution status of the soil and plant species. The results showed that concentrations of $\mathrm{Pb}, \mathrm{Cu}$ and $\mathrm{Zn}$ in the topsoil exceeded international standards at close proximity to point of spills $(0-200 \mathrm{~m})$, while Cd concentrations exceeded the international standard at all the locations. Only $\mathrm{Cd}$ exceeded the international standard in the subsoil. Contamination $\left(P_{i}\right)$ and integrated pollution $\left(P_{c}\right)$ indices of the topsoil showed reducing trends from the point of pollution, and locations at $0 \mathrm{~m}$ and $100 \mathrm{~m}$ exhibited high $P_{c}$, while those at $200 \mathrm{~m}$ showed moderate $P_{c}$ by all metals. The levels of $\mathrm{Pb}$ and $\mathrm{Cd}$ in the diagnostic species exceeded the World Health Organization limits and the pollution load index (PLI) portrayed severe contamination. In conclusion, the impact of crude-oil spills in the area was significant; soil remediation is important to avert ecological and human health disasters. Moreover, these findings will be useful for designing strategic measures for environmental control in the area.
\end{abstract}

Keywords: oil spillage, integrated pollution index, soil remediation, pollution load index.

\section{Introduction}

In the quest for industrialisation and greater economic empowerment, many developing countries, including Nigeria, have interfered with the environment to the extent that there is currently widespread environmental degradation and devastation with attendant climatic, economic and health effects. Since the beginning of petroleum production in Nigeria in 1958, many documents are available on the petroleum spills into agricultural lands through petroleum production operations (Odu et al., 1985; Imoobe \& Iroro, 2009). Although, the petroleum industry has contributed immensely to the economy and development of Nigeria, oil exploration, transportation and marketing operations have also presented some attendant negative impacts on the environment. Ozurumba (1999) showed that in 1999 alone about 47 major oil spillages due to vandalisation occurred in Nigeria resulting in damage to lives, plants and animals. Between 1976 and 1996, Gideon \& Josephine (2008) reported that over 647 spillages occurred spilling 2,369,407.04 barrels of crude oil with only $549,060.38$ barrels $(23 \%)$ being recovered, while $1,820,410.50$ barrels $(77 \%)$ were lost to the environment. The cause of these serious spillages was attributed to blowouts, sabotage, corrosion of pipelines, equipment failure, operator or maintenance error, third party accelerant, natural spills and misery spills (Imoobe \& Iroro, 2009). Ekundayo \& Obuekwe 
(2000) indicted oil spills for the introduction of heavy metals such as $\mathrm{Cu}, \mathrm{Ni}$ and $\mathrm{Hg}$ into the soil, which impair the biota due to their toxicity. Oil spill affects the physical-chemical properties of the soil, such as temperature, structure, nutrient status and $\mathrm{pH}$. The effects of heavy metal pollution may be immediate if crops planted in spill sites which have accumulated the metals are consumed by man and livestock.

Okordia and Oya in Ikarama community are hosts to Agip and Shell companies, but very little has been documented with respect to the impact of their activities on immediate environment. Based on this, the community needs to be environmentally audited from time to time so as to advise the stakeholders in the petrochemical industries, the government and the local communities on the potential health risks posed by the oil industry. Several studies have also indicated that metal pollution (e.g. $\mathrm{Pb}, \mathrm{Cd}$ and $\mathrm{Ni}$ ) is responsible for certain diseases of humans and animals (Gustav, 1974; Nolan, 2003; Young, 2005); and thus, there is a need for cleaning up oil-contaminated soil. So far, phytoremediation has proved to be cheaper and sustainably feasible in cleaning up pollutants from the soil (Joner et al., 2004). Hence, identification of plants growing in oil-spill impacted land with potentials to accumulate metals is imperative in order to establish suitable plants for the clean-up of metals in oil-spill impacted locations. Therefore, this study was undertaken to investigate the impact of oil spill on the soil and vegetation of this oil-rich community with respect to their heavy metal loads.

\section{Materials and methods \\ 2.1 Study area}

The study sites Okordia and Oya are in Ikarama $\left(05^{\circ} 09^{\prime} 16^{\prime \prime} \mathrm{N}, \quad 06^{\circ} 27^{\prime} 11 \mathrm{E}\right)$, a small community situated within Yenogoa Local Government Area, Bayelsa State, Nigeria (Figure 1). Bayelsa state is strategically located at the centre of the Niger Delta region of Nigeria, which is one of the richest wetlands in the world with a tropical climatic condition of a rainy season (April to November) and a dry season (December to March) and an annual rainfall ranging between 1,500 and 4,000 mm (Kuruk, 2004). Ikarama community is a host to Nigeria's Agip Oil Company and Shell Petroleum Development Company (SPDC). The SPDC pipelines linking Delta, Bayelsa and River states in Nigeria pass through Ikarama community and oil spills from equipment failure have been reported to be the major environmental contamination of this community (MOEN, 2008). The 2 study sites were chosen because of the frequent occurrence of oil spills in the sites. For example, 421 crude oil spills occurred between 18 December 1991 and 23 August 2008 in the state, while 9 major oil spills occurred within Ikarama community (MOEN, 2008). Moreover, more recent crude oil spills also occurred in December 2008 and June 2009 in Oya and Okordia, respectively.

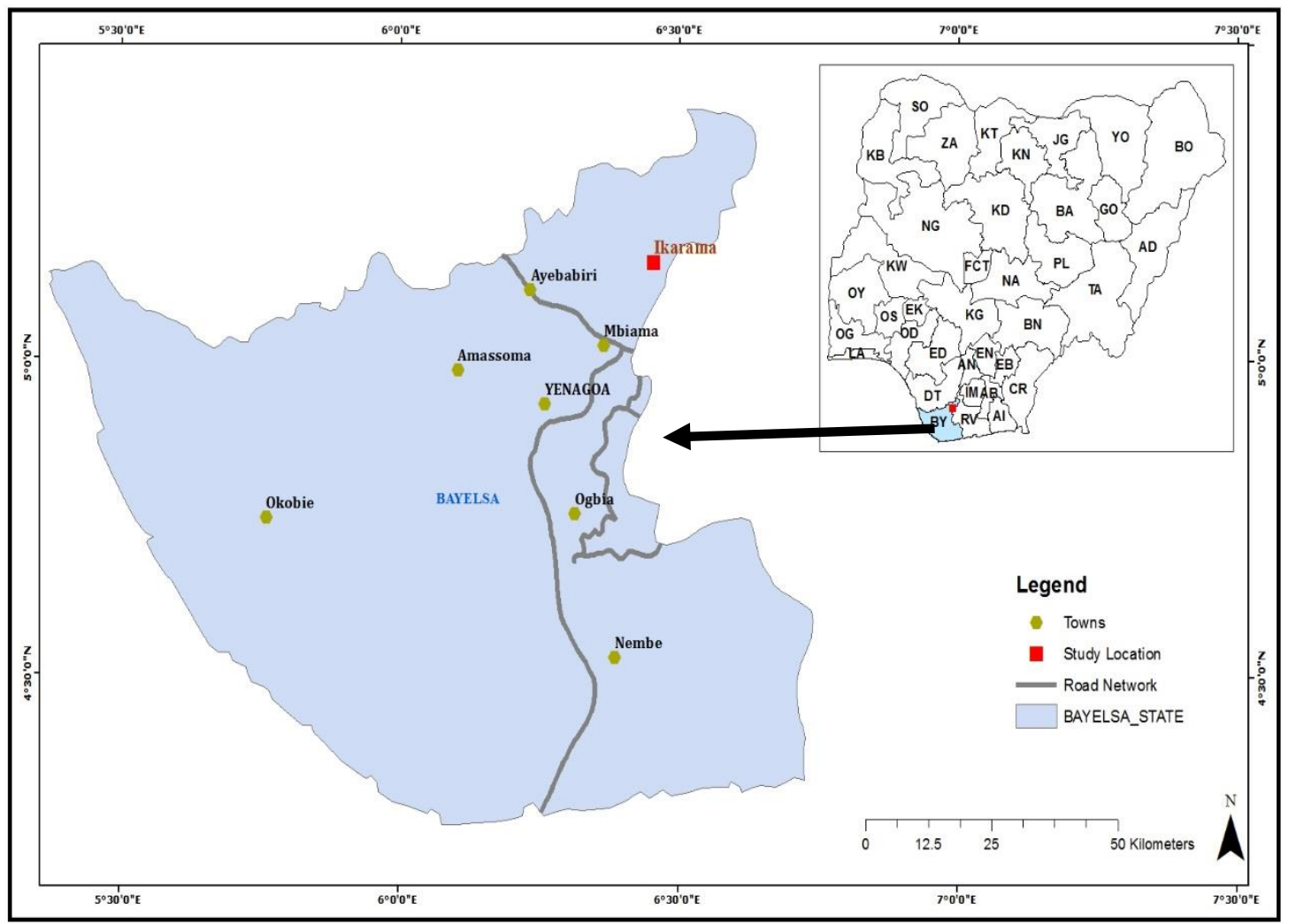

Figure 1. Map of Bayelsa state showing Ikarama community where the 2 study sites are located. Inset: Map of Nigeria showing different states. 


\subsection{Sampling and chemical analysis}

Soil and plant samples were collected from 2 oilspill impacted sites at Okordia and Oya and the sampling activities were carried out in September 2009. At each crude-oil impacted site, a line transect was set from the centre point of the spill in any accessible direction and soil samples were collected at every $100 \mathrm{~m}$ along the transect to a distance of $400 \mathrm{~m}$. The short transect distance was premised on the fact that most of the area was inundated with seawater. At every sampling point, 5 soil samples were randomly collected from the depth of $0-15 \mathrm{~cm}$ and $15-25 \mathrm{~cm}$, respectively (topsoil and subsoil, respectively), with a stainless soil auger, and a total of 50 soil samples (25 samples each of topsoil and subsoil) were collected in each site. The dominant plant species - Gamba grass (Andropogon gayanus) - was sampled at every point of soil collection in the 2 sites, while the samples that served as the control were collected at Zarama, a location that has not experienced crude oil spill. Roots of the samples were discarded at the site and the shoots were properly packed in a paper bag and labelled for laboratory analysis.

The soil samples were air-dried at room temperature, sieved through a $2-\mathrm{mm}$ mesh and ground into fine powder. One (1) $\mathrm{g}$ of the soil sample was wetdigested using the Aqua regia method described by ISO (2002). The resulting digestate was filtered using Whatman No 42 filter paper into a beaker and diluted with deionised water to make up $25 \mathrm{~mL}$. Four metal concentrations $(\mathrm{Pb}, \mathrm{Cd}, \mathrm{Cu}$, and $\mathrm{Zn}$ ) were determined by flame atomic absorption spectrophotometer (Bulk Scientific 210VGP, USA). One (1) g of the powdered plant sample was digested in $10 \mathrm{~mL}$ of conc. $\mathrm{HNO}_{3}$ on a hot plate until fumes turned white. The solution was filtered using Whatman No 42 filter paper and analysed for $\mathrm{Pb}, \mathrm{Cd}, \mathrm{Cu}$ and $\mathrm{Zn}$ using the FAAS (Bulk Scientific 210VGP, USA).

Procedural blanks and replicates' digestion were carried out for QA/QC. A calibration graph for each element determined by the AAS was drawn by using a series of working standard solutions (CPI International, USA) and correlation coefficients greater than 0.850 were obtained for all the elements. The soil $\mathrm{pH}$ was determined in a soil-deionised water suspension $(1: 2.5 \mathrm{w} / \mathrm{v})$ by a calibrated $\mathrm{pH}$ meter (PHS3C model); electrical conductivity (EC) was determined using a conductivity bridge (Hanna EC214 model) and soil particle size fractions were determined by the method of Bouyoucos (1962).

\subsection{Statistical analyses and assessment of metal pollution}

The data generated were subjected to the analysis of variance (ANOVA) and the means were separated with Duncan multiple range test (DMRT) using the Statistic Package for Social Sciences (SPSS) and Excel 2007 for Windows version 16. Student $t$ test was employed to test a significant difference between the metal in the soil and the diagnostic plant, while Pearson coefficient of correlation was used to determine the relationship between the metal in the soil and the plant at $p<0.05$, respectively.

Heavy metal pollution of the soil was assessed by the use of the contamination index $\left(P_{i}\right)$ and integrated contamination index $\left(P_{c}\right)$ models suggested by Huang (1987). The expression for the models is represented in Equations 1-4 and the applied threshold values $\left(\mathrm{mg} \mathrm{kg}^{-1}\right)$ are presented in Table 1 .

$$
\begin{aligned}
P_{i} & ={ }^{\mathrm{C}} / \mathrm{X}_{a} \quad\left[C_{i} \leq \mathrm{X}_{a}\right] \\
P_{i} & =1+\left\lceil\mathrm{C}^{\mathrm{C}}-\mathrm{X}_{a} / \mathrm{X}_{b}-\mathrm{X}_{a}\right\rceil\left[X_{a}<C_{i} \leq X_{b}\right] \\
P_{i} & =2+\left\lceil\mathrm{C}^{\mathrm{C}}-\mathrm{X}_{b} / \mathrm{X}_{c}-\mathrm{X}_{b}\right\rceil\left[X_{b}<C_{i} \leq X_{c}\right] \\
P_{i} & =3+\left\lceil^{\mathrm{C}_{i}-\mathrm{X}_{c}} / \mathrm{X}_{c}-\mathrm{X}_{b}\right\rceil\left[C_{i}>X_{c}\right]
\end{aligned}
$$

where $\mathrm{C}_{\mathrm{i}}$ is the metal concentration in the soil; $X_{a}$ is the bo-pollution threshold value; $X_{b}$ is the lowly polluted threshold value and $X_{c}$ is the highly polluted value. The threshold values of $X_{a}, X_{b}$ and $X_{c}$ are defined in Table 1 based on the Chinese Environmental Quality Standard for soils (SETAC, 1995).

The integrated contamination index $\left(P_{c}\right)$ for each study distance was calculated by the following formula:

$$
\mathrm{P}_{c}=\sum_{i=1}^{n}\left(\mathrm{P}_{i}-1\right)
$$

The classes of $P_{i}$ and $P_{c}$ according to Huang (1987) are presented in Table 2.

Table. 1. Threshold values $(\mathrm{mg} / \mathrm{kg})$ for contamination index $\left(P_{i}\right)$ (SETAC, 1995).

\begin{tabular}{||c|c|c|c|c|}
\hline & $\mathbf{P b}$ & $\mathbf{C d}$ & $\mathbf{C u}$ & $\mathbf{Z n}$ \\
\hline$X_{a}$ & 35 & 0.2 & 35 & 100 \\
\hline$X_{b}$ & 250 & 0.3 & 50 & 200 \\
\hline$X_{c}$ & 500 & 1.0 & 400 & 500 \\
\hline
\end{tabular}

Table 2. Classes of contamination index $\left(P_{i}\right)$ and integrated pollution index $\left(P_{c}\right)$ (Huang, 1987; D'Souza et al., 2013).

\begin{tabular}{||c|c|c||}
\hline Class & $\begin{array}{c}\text { Contamination } \\
\text { index }\left(\boldsymbol{P}_{\boldsymbol{i}}\right)\end{array}$ & $\begin{array}{c}\text { Integrated } \\
\text { pollution index }\left(\boldsymbol{P}_{\boldsymbol{c}}\right)\end{array}$ \\
\hline No & $P_{i} \leq 1$ & $P_{c} \leq 0$ \\
\hline Low & $1 \leq P_{i} \leq 2$ & $0<P_{c} \leq 7$ \\
\hline Moderate & $2 \leq P_{i} \leq 3$ & $7<P_{c} \leq 21$ \\
\hline High & $P_{i}>3$ & $P_{c}>21$ \\
\hline
\end{tabular}

The heavy metal pollution status of the diagnostic species was assessed using the contamination factor (CF) and the pollution load index (PLI) suggested by Fernandez \& Carballeira (2001) and Kalavrouzioti et al. (2012), respectively:

$$
C F=C_{m} / C_{b}
$$

where $C_{m}$ is concentration of the metal determined in the plant species; $C_{b}$ is concentration of the metal determined in the control. 
$\mathrm{CF}<1$ - showed no contamination (NC); $1<\mathrm{CF}<2 \quad-$ suspected contamination (SC); $2<\mathrm{CF}<3.5-$ slight contamination (SLC); $3.5<\mathrm{CF}<8-$ moderate contamination (MC); $8<\mathrm{CF}<27$ - severe contamination (SEC); and $\mathrm{CF}>27$ - extreme contamination (EC) (GonzalezMiqueo et al., 2010).

$$
P L I=n \sqrt{\sum_{i=1}^{n} C F_{1} \times C F_{2} \times C F_{n}}
$$

Values of PLI close to 1 indicate that elemental loads of plant species are near to the background level, PLI 1-3 shows moderate pollution, and values > 3 indicate severe pollution (Daud et al., 2006).

\section{$3 \quad$ Results and discussion}

\subsection{Level of heavy metals in topsoil and subsoil}

The characteristics of the topsoil in the study sites are presented in Table 3. The topsoil was predominantly sandy with less than $2 \%$ silt and $8 \%$ clay and acidic. The sandy portions were found to constitute more than $90 \%$ of the topsoil in Okordia and Oya. The $\mathrm{pH}$ values of the soil ranged from 4.66 to 5.6 and from 4.09 to 4.76 for Okordia and Oya, respectively, showing that the soils were acidic. Increased acidity has been reported to enhance mobility, solubility and availability of elements in soils (Odu et al., 1985; Sauve et al., 1997). The acidic nature of the soil of the area is not surprising because most of the soils in the south-south geographical zone of Nigeria are acidic and which may be due to their exposure to excessive precipitation leading to leaching of the basic cations and being replaced by hydrogen ion (Ngobiri et al., 2007). This finding was consistent with the reports of Osuji \& Nwoye (2007) as they also reported a $\mathrm{pH}$ range of 4.9-5.1 in crude-oil polluted soil and 5.6 in unpolluted soil. The electrical conductivity (EC) of the 2 oil-impacted sites range from 0.08 to $0.15 \mathrm{dS} / \mathrm{m}$ and from 0.07 to $0.18 \mathrm{dS} / \mathrm{m}$ for Okordia and Oya, respectively. The high EC observed in these impacted soils may be linked to the crude-oil spill, suggesting the presence of highly soluble solutes.

Table 3. Physico-chemical characteristics of topsoil of Okordia and Oya.

\begin{tabular}{||c|c|c|c|c|c|c||}
\hline & & \multicolumn{5}{|c||}{ Soil characteristics } \\
\hline Location & Distance (m) & Sand (\%) & Silt (\%) & Clay (\%) & pH (1:2.5) & EC (dS m-1) (1:2.5) \\
\hline Okordia & 400 & $93.07 \pm 1.79$ & $1.67 \pm 0.75$ & $5.27 \pm 2.54$ & $4.82 \pm 0.61$ & $0.08 \pm 0.05$ \\
\hline & 300 & $93.63 \pm 2.51$ & $0.60 \pm 0.20$ & $5.73 \pm 2.39$ & $5.06 \pm 0.90$ & $0.09 \pm 0.06$ \\
\hline & 200 & $91.60 \pm 2.21$ & $1.73 \pm 0.91$ & $6.67 \pm 2.75$ & $4.66 \pm 1.07$ & $0.08 \pm 0.03$ \\
\hline & 100 & $91.27 \pm 2.01$ & $1.77 \pm 0.93$ & $6.93 \pm 2.47$ & $5.09 \pm 0.77$ & $0.13 \pm 0.02$ \\
\hline & 0 & $93.43 \pm 2.68$ & $1.23 \pm 1.02$ & $5.17 \pm 2.79$ & $5.62 \pm 0.55$ & $0.15 \pm 0.03$ \\
\hline Oya & 400 & $87.57 \pm 3.19$ & $2.17 \pm 0.60$ & $6.93 \pm 2.11$ & $4.44 \pm 0.58$ & $0.07 \pm 0.01$ \\
\hline & 300 & $91.17 \pm 2.47$ & $1.63 \pm 0.95$ & $7.20 \pm 2.25$ & $4.76 \pm 1.09$ & $0.08 \pm 0.02$ \\
\hline & 200 & $91.90 \pm 1.45$ & $1.77 \pm 0.85$ & $6.33 \pm 1.59$ & $4.09 \pm 0.58$ & $0.09 \pm 0.03$ \\
\hline & 100 & $92.37 \pm 0.81$ & $1.73 \pm 0.91$ & $5.90 \pm 1.47$ & $4.69 \pm 1.34$ & $0.12 \pm 0.08$ \\
\hline & 0 & $91.73 \pm 1.05$ & $1.17 \pm 1.08$ & $7.10 \pm 1.37$ & $4.76 \pm 1.23$ & $0.18 \pm 0.01$ \\
\hline
\end{tabular}

Heavy metal contents of the topsoil of Okordia and Oya at various distances are shown in Table 4. It was evident that metal concentrations of the soil decreased significantly $(\mathrm{P}<0.05)$ as the distance increased from the point of the spill; and metal concentrations were consistently and significantly higher $(\mathrm{P}<0.05)$ at $0 \mathrm{~m}$.

Table 4. Heavy metal contents ( $\left.\mathrm{mg} \mathrm{kg}^{-1}\right)$ of topsoil of Okordia and Oya.

\begin{tabular}{|c|c|c|c|c|c|}
\hline Site & Distance (m) & \multicolumn{4}{|c|}{ Concentration (mean \pm SD) } \\
\hline & & $\mathbf{P b}$ & Cd & $\mathrm{Cu}$ & $\mathbf{Z n}$ \\
\hline Okordia & 400 & $19.7 \pm 2.4^{\mathrm{e}}$ & $5.1 \pm 0.25^{\mathrm{d}}$ & $18.7 \pm 0.7^{\mathrm{d}}$ & $181.3 \pm 17.2^{\mathrm{d}}$ \\
\hline & 300 & $23.7 \pm 1.1^{\mathrm{c}}$ & $5.9 \pm 0.35^{\mathrm{d}}$ & $21.6 \pm 0.8^{\mathrm{d}}$ & $185.3 \pm 15.0^{\mathrm{d}}$ \\
\hline & 200 & $41.0 \pm 6.2^{\mathrm{c}}$ & $7.0 \pm 0.6^{\mathrm{c}}$ & $37.3 \pm 7.6^{\mathrm{c}}$ & $201.0 \pm 34.6^{\mathrm{c}}$ \\
\hline & 100 & $88.2 \pm 4.2^{b}$ & $9.3 \pm 2.0^{b}$ & $82.0 \pm 18.5^{\mathrm{b}}$ & $223.7 \pm 38.1 \mathrm{a}^{\mathrm{b}}$ \\
\hline & 0 & $128.1 \pm 12.5^{\mathrm{a}}$ & $10.7 \pm 3.12^{\mathrm{a}}$ & $116.8 \pm 7.8^{\mathrm{a}}$ & $285.0 \pm 43.8^{\mathrm{a}}$ \\
\hline Oya & 400 & $19.8 \pm 4.9^{\mathrm{e}}$ & $5.2 \pm 0.2^{\mathrm{d}}$ & $19.8 \pm 0.8^{\mathrm{d}}$ & $184.6 \pm 16.0^{\mathrm{d}}$ \\
\hline & 300 & $23.3 \pm 6.5^{\mathrm{c}}$ & $2.2 \pm 0.2^{\mathrm{e}}$ & $22.6 \pm 1.4^{\mathrm{d}}$ & $190.7 \pm 16.8^{\mathrm{d}}$ \\
\hline & 200 & $34.0 \pm 8.2^{\mathrm{c}}$ & $6.7 \pm 3.1^{\mathrm{c}}$ & $32.7 \pm 8.8^{\mathrm{c}}$ & $221.7 \pm 38.4^{\mathrm{c}}$ \\
\hline & 100 & $82.5 \pm 23.3^{b}$ & $9.2 \pm 2.7^{b}$ & $78.5 \pm 15.0^{\mathrm{b}}$ & $272.5 \pm 77.6^{\mathrm{b}}$ \\
\hline & 0 & $115.0 \pm 14.2^{\mathrm{a}}$ & $11.0 \pm 3.7^{\mathrm{a}}$ & $120.8 \pm 3.6^{\mathrm{a}}$ & $309.3 \pm 63.5^{\mathrm{a}}$ \\
\hline CCME $^{*}$ & & 70 & 1.4 & 63 & 200 \\
\hline
\end{tabular}

Values with the same superscript along the same column are not statistically different at $p \leq 0.05$.

* - CCME limits for metals in agricultural soils.

The concentrations of $\mathrm{Pb}, \mathrm{Cu}$ and $\mathrm{Zn}$ at $0 \mathrm{~m}$ doubled the concentrations at $300 \mathrm{~m}$ and $400 \mathrm{~m}$, whereas the concentrations of $\mathrm{Cd}$ were in several folds of metal concentrations at $300 \mathrm{~m}$. It is clear that the high concentrations of heavy metals in the topsoil up to $300 \mathrm{~m}$ distance in the 2 sites are resultant effects of 
the crude-oil spill. Essoka et al. (2006) reported high concentrations of $\mathrm{Pb}$ and $\mathrm{Cd}$ in the soil around a crudeoil polluted site in Warri, Delta state in Nigeria. Comparing the metal loads of the topsoil of the 2 crude-oil impacted areas with the limits stipulated for agricultural soil by the Canadian Council of Minister of Environment (CCME) (2007), it was observed that the concentrations of $\mathrm{Pb}$ and $\mathrm{Cu}$ in the topsoil exceeded CCME limits up to $100 \mathrm{~m}$ distance. Cd concentrations at the 2 sites were also several folds greater than the CCME limit, while $\mathrm{Zn}$ concentrations exceeded the CCME limit up to $200 \mathrm{~m}$ distance (Table 4).

These elevated values of heavy metals in the soil of Okordia and Oya of Ikarama suggest anthropogenic inputs into the soil due to several crude oil spillages in the area since more than 60 metals have been established to be in crude oil (Nduka et al., 2012). The fact that there is significant metal pollution in the area becomes ecologically significant due to the agrarian nature of the community and the possibility of toxic metals being transferred up the food chain, thereby portending human health hazards.

The heavy metal loads in the subsoil of Okordia and Oya are shown in Table 5. Generally, the concentrations of $\mathrm{Pb}, \mathrm{Cd}, \mathrm{Cu}$ and $\mathrm{Zn}$ in the subsoil were lower than the concentrations in the topsoil. The subsoil of the 2 sites was contaminated with $\mathrm{Cd}$ at all locations, while $\mathrm{Zn}$ contamination was up to $200 \mathrm{~m}$ when compared with the CCME limits. The same pattern of reduction of metal concentrations in the topsoil as the distance increases was also observed for the subsoil.

Table 5. Heavy metal content $\left(\mathrm{mg} \mathrm{kg}^{-1}\right)$ of subsoil of Okordia and Oya.

\begin{tabular}{||c|c|c|c|c|c||}
\hline Site & Distance (m) & \multicolumn{4}{|c||}{ Concentration (mean \pm SD) } \\
\hline & & Pb & Cd & Cu & Zn \\
\hline Okordia & 400 & $5.1 \pm 1.50^{\mathrm{d}}$ & $2.5 \pm 0.1^{\mathrm{d}}$ & $5.0 \pm 1.3^{\mathrm{c}}$ & $54.6 .1 \pm 6.8^{\mathrm{e}}$ \\
\hline & 300 & $4.8 \pm 0.37^{\mathrm{d}}$ & $2.8 \pm 0.1^{\mathrm{d}}$ & $5.6 \pm 0.7^{\mathrm{c}}$ & $185.3 \pm 4.12^{\mathrm{d}}$ \\
\hline & 200 & $6.3 \pm 1.1^{\mathrm{c}}$ & $3.0 \pm 0.2^{\mathrm{c}}$ & $7.3 \pm 1.0^{\mathrm{b}}$ & $201.0 \pm 33.6^{\mathrm{c}}$ \\
\hline & 100 & $8.8 \pm 1.7^{\mathrm{b}}$ & $3.6 \pm 0.1^{\mathrm{b}}$ & $8.8 \pm 0.8^{\mathrm{b}}$ & $223.7 \pm 38.1^{\mathrm{b}}$ \\
\hline & 0 & $11.0 \pm 1.0^{\mathrm{a}}$ & $3.8 \pm 0.1^{\mathrm{a}}$ & $12.3 \pm 0.2^{\mathrm{a}}$ & $277.2 \pm 43.8^{\mathrm{a}}$ \\
\hline Oya & 400 & $4.5 \pm 0.6^{\mathrm{d}}$ & $2.6 \pm 0.1^{\mathrm{e}}$ & $4.5 \pm 0.6^{\mathrm{d}}$ & $184.6 \pm 16.0^{\mathrm{d}}$ \\
\hline & 300 & $6.8 \pm 1.0^{\mathrm{c}}$ & $3.0 \pm 0.2^{\mathrm{c}}$ & $4.7 \pm 0.8^{\mathrm{d}}$ & $190.6 \pm 16.7^{\mathrm{d}}$ \\
\hline & 200 & $8.1 \pm 0.5^{\mathrm{b}}$ & $2.8 \pm 0.5^{\mathrm{d}}$ & $5.2 \pm 1.5^{\mathrm{c}}$ & $221.7 \pm 33.7^{\mathrm{b}}$ \\
\hline & 100 & $10.0 \pm 0.8^{\mathrm{a}}$ & $3.1 \pm 0.7^{\mathrm{b}}$ & $11.5 \pm 1.7^{\mathrm{b}}$ & $272.5 \pm 77.5^{\mathrm{a}}$ \\
\hline CCME & 0 & $10.8 \pm 0.5^{\mathrm{a}}$ & $3.5 \pm 0.3^{\mathrm{a}}$ & $13.6 \pm 1.7^{\mathrm{a}}$ & $209.2 \pm 63.2^{\mathrm{c}}$ \\
\hline
\end{tabular}

Values with the same superscript along the same column are not statistically different at $p \leq 0.05$.

\subsection{Level of heavy metals in the diagnostic species Andropogon gayanus}

The concentrations of metals in Andropogon gayanus (Gamba grass) used as biomonitor in this study are presented in Table 6. Generally, Gambia grass in the control had the lowest values of metals. The highest concentration of metals in the diagnostic plant was obtained at the point of the spill $(0 \mathrm{~m})$ and subsequently decreased significantly $(\mathrm{P}<0.05)$ away from the source point of pollution up to $300 \mathrm{~m}$ away. This reported reduction in metal concentration in the diagnostic plant as the distance increased from the source point of pollution has been earlier reported by Bada \& Olarinle (2012).

Table 6. Heavy metal content $\left(\mathrm{mg} \mathrm{kg}^{-1}\right)$ of Andropogon gayanus growing at various locations in the study sites.

\begin{tabular}{||c|c|c|c|c|c||}
\hline \hline & & \multicolumn{4}{|c||}{ Concentration (mean \pm SD) } \\
\hline Site & Distance (m) & $\mathbf{P b}$ & $\mathbf{C d}$ & $\mathbf{C u}$ & $\mathbf{Z n}$ \\
\hline Okordia & 400 & $4.5 \pm 1.25^{\mathrm{d}}$ & $0.25 \pm 0.05^{\mathrm{d}}$ & $4.1 \pm 0.05^{\mathrm{e}}$ & $8.0 \pm 0.12^{\mathrm{d}}$ \\
\hline & 300 & $3.5 \pm 0.25^{\mathrm{e}}$ & $0.5 \pm 0.25^{\mathrm{c}}$ & $5.6 \pm 0.64^{\mathrm{d}}$ & $7.8 \pm 0.37^{\mathrm{d}}$ \\
\hline & 200 & $4.2 \pm 0.12^{\mathrm{c}}$ & $0.75 \pm 0.25^{\mathrm{c}}$ & $6.5 \pm 0.12^{\mathrm{c}}$ & $16.1 \pm 0.37^{\mathrm{c}}$ \\
\hline & 100 & $4.7 \pm 0.12^{\mathrm{b}}$ & $1.2 \pm 0.07^{\mathrm{b}}$ & $7.7 \pm 0.02^{\mathrm{b}}$ & $27.2 \pm .75^{\mathrm{b}}$ \\
\hline & 0 & $6.3 \pm 0.25^{\mathrm{a}}$ & $3.5 \pm 1.5^{\mathrm{a}}$ & $9.0 \pm 0.12^{\mathrm{a}}$ & $31.7 \pm 4.25^{\mathrm{a}}$ \\
\hline Oya & 400 & $4.6 \pm 0.12^{\mathrm{d}}$ & $0.25 \pm 0.25^{\mathrm{e}}$ & $2.5 \pm 2.87^{\mathrm{e}}$ & $6.5 \pm 0.25^{\mathrm{d}}$ \\
\hline & 300 & $4.8 \pm 0.12^{\mathrm{d}}$ & $0.5 \pm 0.05^{\mathrm{d}}$ & $5.2 \pm 0.05^{\mathrm{d}}$ & $7.5 \pm 0.03^{\mathrm{c}}$ \\
\hline & 200 & $6.3 \pm 0.25^{\mathrm{b}}$ & $1.0 \pm 0.05^{\mathrm{c}}$ & $6.3 \pm 0.12^{\mathrm{c}}$ & $12.7 \pm 0.12^{\mathrm{b}}$ \\
\hline & 100 & $6.0 \pm 0.62^{\mathrm{c}}$ & $1.2 \pm 0.5^{\mathrm{b}}$ & $7.7 \pm 0.03^{\mathrm{b}}$ & $26.0 \pm 0.62^{\mathrm{a}}$ \\
\hline Control & 0 & $8.1 \pm 0.62^{\mathrm{a}}$ & $2.2 \pm 1.50^{\mathrm{a}}$ & $9.1 \pm 0.11^{\mathrm{a}}$ & $26.7 \pm 0.25^{\mathrm{a}}$ \\
\hline WHO limit & & $2.0 \pm 0.50$ & $0.2 \pm 1.00$ & $1.6 \pm 0.12$ & $4.0 \pm 0.12$ \\
\hline Phytotoxic level $^{\mathrm{a}}$ & & 2.0 & 0.2 & 10 & $\mathrm{n} . \mathrm{a}$. \\
\hline \hline
\end{tabular}

Values with the same superscript along the same column are statistically the same at $p \leq 0.05 ;{ }^{*}-$ WHO Permissible limit in plants; ${ }^{a}$ - Varun et al. (2010).

Compared with the WHO (1996) permissible limits of metals in plants, $\mathrm{Pb}$ and $\mathrm{Cd}$ exhibited elevated concentrations beyond the WHO limits at all locations. Ling et al. (2007) have asserted that heavy metal contamination of the soil may pose risks and hazards to humans through the food chain, which is 
soil-plant-human or soil-plant-animal-human, as well as reduction in food quality via phytotoxicity. Meanwhile, the concentrations of all the metals in $A$. gayanus were below the phytotoxic levels in plants as presented by Varun et al. (2010); and this could explain its continued survival in the presence of the elevated metal concentrations in the soil. There is also the possibility of A. gayanus being excluder of these heavy metals as the concentrations never reached phytotoxic levels despite their abundance in the soil of the area.

Student $t$ test used to compare the metal contents of the topsoil with the grass and the Pearson correlation coefficient are presented in Table 7. The concentrations of heavy metals in the topsoil positively and significantly correlated $(p<0.05)$ with the concentrations of metals in A. gayanus, except $\mathrm{Cd}$ at Oya. This indicates the possibility of A. gayanus taking up the heavy metals solely from the polluted topsoil. Metals in A. gayanus were significantly lower than their corresponding concentrations in the topsoil at $p<0.05$ (Table 7). This also evidently proves that high concentrations of metals in the soil do not always indicate similar high concentrations in plants; the extent of accumulation depends on plant and heavy metal species (Hart et al., 2005).

Table 7. Pearson correlation coefficients $(r)$ and Student $t$ test between metals in topsoil and Andropogon gyanus in the study sites.

\begin{tabular}{||c|c|c|c|c||}
\hline & \multicolumn{2}{|c|}{$\begin{array}{c}\text { Pearson correlation } \\
(\mathbf{r})\end{array}$} & \multicolumn{2}{c||}{ Student $\boldsymbol{t}$ test } \\
\hline Metal & Okordia & Oya & Okordia & Oya \\
\hline$P b$ & $0.725^{* *}$ & $0.844^{* *}$ & $4.790^{* *}$ & $0.808^{* *}$ \\
\hline$C d$ & $0.746^{* *}$ & 0.360 & $10.232^{* *}$ & $5.600^{* *}$ \\
\hline$C u$ & $0.908^{* *}$ & $0.828^{* *}$ & $4.703^{* *}$ & $4.566^{* *}$ \\
\hline $\mathrm{Zn}$ & $0.798^{* *}$ & $0.756^{* *}$ & $16.350^{* *}$ & $13.078^{* *}$ \\
\hline
\end{tabular}

\subsection{Pollution assessment of topsoil and diagnostic species}

The pollution assessment of the topsoil using the contamination index $\left(P_{i}\right)$ and the integrated pollution index $\left(P_{c}\right)$ is presented in Figure 2.
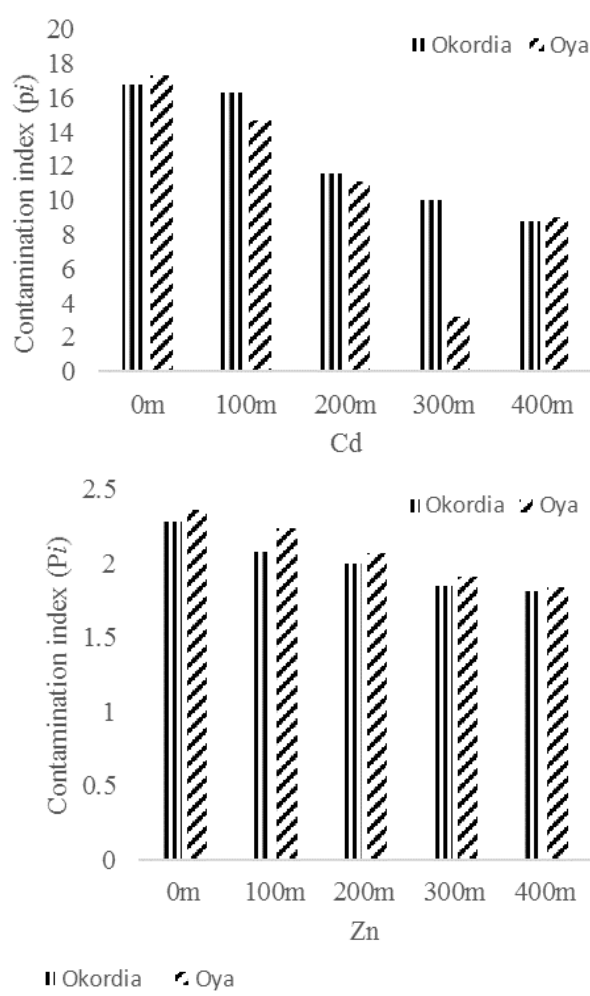

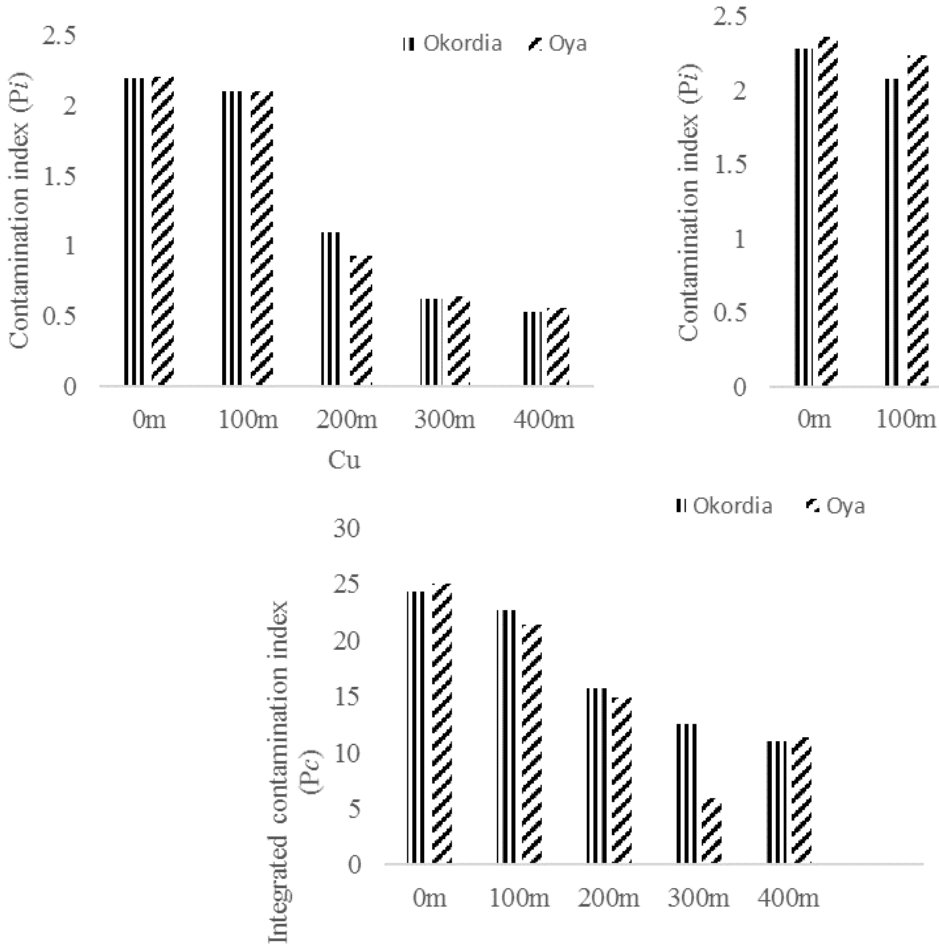

Figure 2. Contamination index $\left(P_{i}\right)$ of $(a) P b,(b) C d,(c) C u,(d) Z n$ and $(e)$ the integrated pollution index $\left(P_{c}\right)$ of the topsoil of the 2 study sites. 
Low contamination by $\mathrm{Pb}\left(1 \leq P_{i}<2\right)$ was observed in the topsoil of Okordia and Oya from $0 \mathrm{~m}$ to $200 \mathrm{~m}$ distance whereas $300 \mathrm{~m}$ and $400 \mathrm{~m}$ locations showed no contamination $\left(P_{i} \leq 1\right)$. High levels of contamination $\left(P_{i}>3\right)$ were recorded in the case of $\mathrm{Cd}$ across all locations. The sites showed moderate contamination $\left(2 \leq P_{i} \leq 3\right)$ of $\mathrm{Cu}$ and $\mathrm{Zn}$ at $0 \mathrm{~m}$ and $200 \mathrm{~m}$, while low contamination of $\mathrm{Zn}$ was observed from $200 \mathrm{~m}$ to $400 \mathrm{~m}$ in the 2 sites. $\mathrm{Pb}$ and $\mathrm{Cu}$ indicated no contamination from $200 \mathrm{~m}$ to $400 \mathrm{~m}$ in the 2 sites. It is noteworthy that the contamination levels in the 2 sites for all the metals showed a reducing trend from the source of pollution, and $\mathrm{Cd}$ was consistently at high levels across the locations.

The integrated contamination index $\left(P_{c}\right)$ values of the locations for the 2 sites are presented in Figure $2 \mathrm{f}$. The same reducing trend of the contamination index $\left(P_{i}\right)$ observed at the 2 sites was also represented in the integrated contamination index $\left(P_{c}\right)$. High integrated $\left(P_{c}>21\right)$ contamination was observed at $0 \mathrm{~m}$ and $100 \mathrm{~m}$ at the 2 sites due to their proximity to the source of pollution. Locations at $200 \mathrm{~m}, 300 \mathrm{~m}$ and $400 \mathrm{~m}$ in Okordia and locations at $200 \mathrm{~m}$ and $400 \mathrm{~m}$ in Oya indicated moderate integrated contamination $(7<$ $\left.P_{c} \leq 21\right)$. The location at $300 \mathrm{~m}$ in Oya indicated low integrated contamination $\left(0<P_{c} \leq 7\right)$. It is clear from the results that all the locations within the 2 sites does not fall within the threshold of no integrated contamination $\left(P_{c} \leq 0\right)$; hence, there is urgent need for remediation of the soil to avert ecological and human health disaster.

The assessment of the contamination level of the diagnostic species (A. gayanus) used in this study is presented in Figure 3.
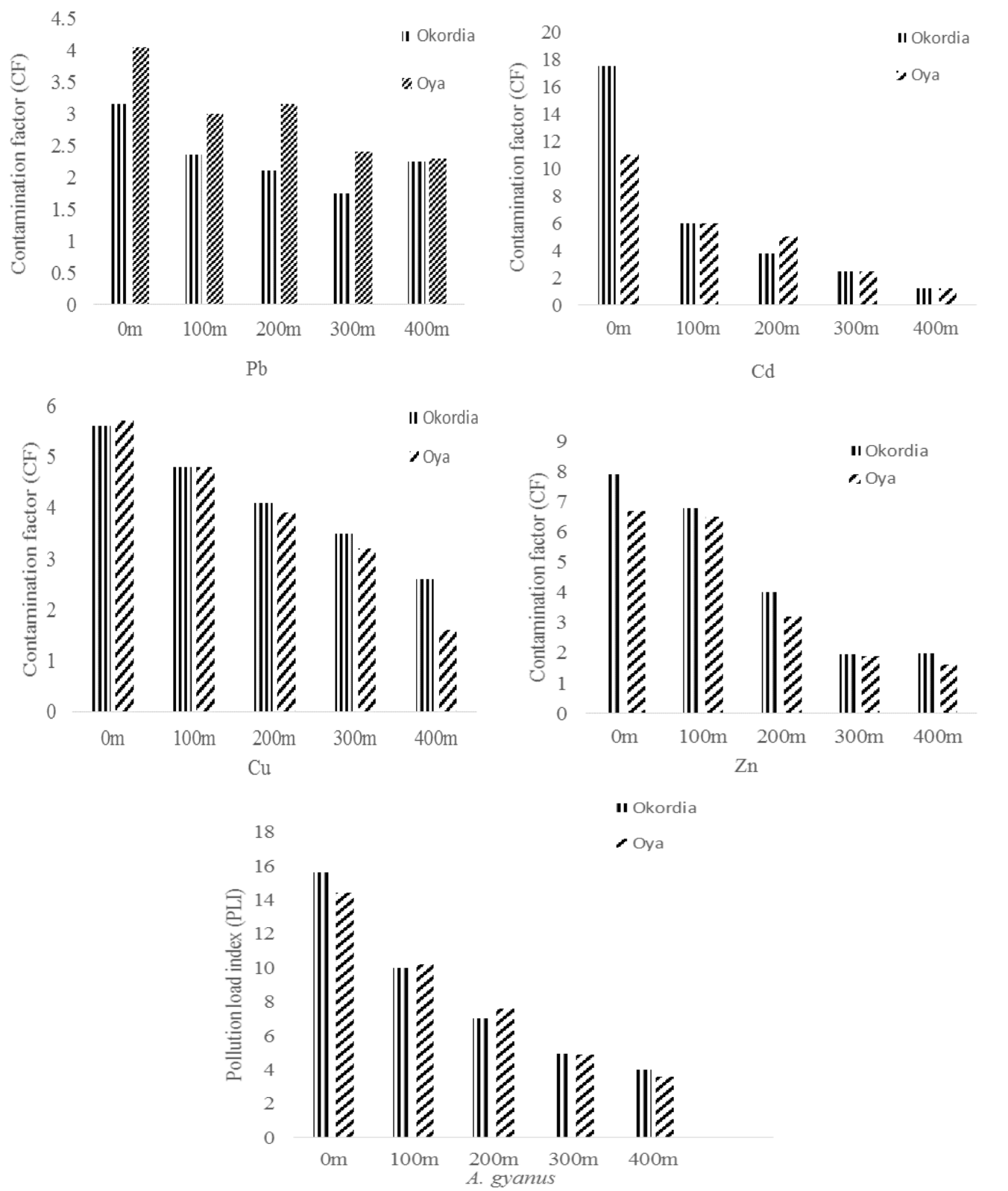

Figure 3. The contamination factor $(C F)$ of $(a) \mathrm{Pb},(b) \mathrm{Cd},(c) \mathrm{Cu},(d) \mathrm{Zn}$ and (e) the pollution load index (PLI) of A. gayanus in the 2 study sites.

The concentrations of $\mathrm{Pb}$ in A. gayanus at $0 \mathrm{~m}$, $100 \mathrm{~m}$ and $400 \mathrm{~m}$ in Okordia were within the slight contamination level. The same level of contamination was observed at $100 \mathrm{~m}$ and $200 \mathrm{~m}$ in Oya, while at $0 \mathrm{~m}$ 
the level of contamination of A. gayanus reached moderate contamination (Figure 3a). The concentrations of $\mathrm{Cd}$ in A. gayanus at $0 \mathrm{~m}$ and $100 \mathrm{~m}$ in Okordia and Oya reached the severe contamination level, while moderate contamination was observed at $200 \mathrm{~m}$ and $300 \mathrm{~m}$ in the 2 sites (Figure 3b). Cu concentrations in A. gayanus at $0 \mathrm{~m}, 100 \mathrm{~m}, 200 \mathrm{~m}$ and $300 \mathrm{~m}$ indicated moderate contamination, while slight contamination and suspected contamination were exhibited at $400 \mathrm{~m}$ in Okordia and Oya, respectively (Figure 3c). Moderate contamination of $\mathrm{Zn}$ was recorded in A. gayanus at $0 \mathrm{~m}, 100 \mathrm{~m}$ and $200 \mathrm{~m}$ in both Okordia and Oya, while at $300 \mathrm{~m}$ and $400 \mathrm{~m}$ suspected contamination of A. gayanus was exhibited (Figure 3d). The pollution load of the index of A. gayanus showed that all locations in the 2 sites were severely contaminated with heavy metals (Figure $3 \mathrm{e})$. This portends a grave ecological problem as food crops planted in this agricultural land can possibly accumulate metals to the levels that portend health implications to animals and humans that depend on them for survival.

\section{Conclusion}

The study has revealed that the several incidences of crude oil spillage have really impacted on the environment of Ikarama with heavy metals. The pollution indices of the soil at $0 \mathrm{~m}$ and $100 \mathrm{~m}$ were high, while the other distances $(200 \mathrm{~m}, 300 \mathrm{~m}$ and $400 \mathrm{~m}$ ) were of low pollution. The high metal pollution of the soil at all the distances was reflected on the diagnostic plants, as A. gayanus showed the severe metal pollution status due to uptake and eventual accumulation of metals to toxic levels in the biomass. It is obviously imperative that the government improve environmental policies to protect the Niger Delta from a degradation effect of oil exploration. It is also important that the Environmental Guidelines and Standards for the Petroleum Industry in Nigeria (EGASPIN) that stipulated that the spiller should be responsible for the clean-up of the site and restoration to the original state should be adequately empowered and enforced on oil prospecting companies in the Niger Delta to reduce the risk and hazard posed by heavy metals to humans and the ecosystem.

\section{Acknowledgements}

The authors express their appreciation to Prof. Oladele of the Department of Plant Biology, University of Ilorin for helping in reviewing the manuscript.

\section{References}

Ekundayo, E. O. \& Obuekwe, O. (2000). Effects of an oil spill on soil physic-chemical properties of a spill site in a Typic Udipsamment of the Niger Delta basin of Nigeria. Environmental Monitoring and Assessment, 60(2), 235-249.
http://dx.doi.org/10.1023/A:1006230025095.

Bada, B. S. \& Olarinle, T. A. (2012). Characteristics of soils and heavy metal content of vegetation in oil spill impacted land in Nigeria. In proceedings of the Annual International Conference on Soils, sediments, Water and Energy vol. 13, article 2.

Bouyoucos, G. J. (1962). Hydrometer method improved for making particle size analysis of soil. Soil Agronomy Journal 54(5), 464-466. http://dx.doi.org/10.2134/agronj1962.00021962005400 $050028 \mathrm{x}$

Canadian Council of Ministers of the Environment (CCME). (2007). Canadian soil quality guidelines for the protection of environmental and human health: summary tables. Canadian Council of Ministers of the Environment, Winnipeg. Excerpt from Publication No. 1299, ISBN 1-896997-34-1.

Daud, M., Khalid, N., Iqbal, J., \& Ahmad, S. (2006). Assessment of atmospheric pollution level using Asclepias procera leaves as biomonitor. Radiochim Acta 95, 423-431.

D’Souza, R., Varun, M., Pratas, J., \& Paul, M. S. (2013). Spatial distribution of heavy metals in soil and flora associated with the glass industry in north central India: implications for phytoremediation. Soil and Sediment: An International Journal 22(1), 1-20. http://dx.doi.org/10.1080/15320383.2012.697936.

Ekundayo, E. O. \& Obuekwe, O. (1997). Effects of oil spill on the physic-chemical properties of a spill site in a paleudult of the Niger Delta basin of Nigeria. Environmental Monitoring and Assessment, 60, 235249. http://dx.doi.org/10.1023/A:1006230025095.

Essoka, P. A., Ubogu, A. E., \& Uzu, L. (2006). An overview of oil pollution and heavy metal concentration in Warri area, Nigeria. Management of Environmental Quality: An International Journal, 17(2), 209-215. http://dx.doi.org/10.1108/14777830610650519.

Fernandez, J. \& Carballeira, A. (2001). Evaluation of contamination by different elements in terrestrial mosses. Archives of Environmental Contamination and Toxicology, 40, 461-468. http://dx.doi.org/10.1007/s002440010198.

Gideon, O. \& Josephine, E. (2008). Levels of heavy metals $(\mathrm{Pb}, \mathrm{Cd}, \mathrm{Zn}, \mathrm{Mg}$ and $\mathrm{Cu}$ ) in cassava from Niger Delta of Nigeria as an indication of soil environmental pollution. Journal of the Chemical Society, 2, 120-143.

Gonzalez-Miqueo, L., Elustondo, D., Lasheras, E., \& Santamaria, J. M. (2010). Use of native mosses as biomonitors of heavy metals and nitrogen deposition in the surrounding of two steel works. Chemosphere, 78, 965-971. http://dx.doi.org/10.1016/i.chemosphere.2009.12.028.

Gustav, R. (1974). Hazardous heavy metals (No. 6, p. 14). WHO International Reference Centre for Waste Disposal (IRCWD News)

Hart, A. D., Oboh, C. A., Barimalaa, I. S., \& Sokari, T. G. (2005). Concentrations of trace metals $(\mathrm{Pb}, \mathrm{Fe}, \mathrm{Cu}$ and $\mathrm{Zn}$ ) in crops harvested in some oil prospecting locations in River state, Nigeria. African Journal of Food Agriculture, Nutrition and Development, 5(2), 34-41.

Huang, R. (1987). Environmental pedology. Beijing, China: Higher Education Press.

Imoobe, T. O. \& Iroro, T. (2009). Ecological restoration of oil spill sites in the Niger Delta, Nigeria. Journal of Sustainable Development in Africa, 11(2), 54-65.

International Organisation for Standardisation (ISO). (2002). Soil quality-Extraction of trace elements soluble in agua regia (pp. 466). ISO 11. 
Joner, E. J., Hirmann, D., Szoler, O. H. J., Todorovic, D., Leyval, L., \& Liobner, A. P. (2004). Priming effects on PAH degradation and ectoxicity during phytoremediation experiment. Environmental Pollution, 128: 429-435. http://dx.doi.org/10.1016/j.envpol.2003.09.005.

Kalavrouziotis, I., Koukoulakis, P., \& Kostakioti, E. (2012). Assessment of metal transfer factor under irrigation with treated municipal wastewater. Agricultural Water Management, 103,114-119. http://dx.doi.org/10.1016/j.agwat.2011.11.002.

Kuruk, P. (2004). Customary Water Laws and Practices in Nigeria. Retrieved from: http://www.fao.org/fileadmin/ templates/legal/docs/CaseStudy_Nigeria.pdf (Accessed 23 November, 2014)

Ling, W., Shen, Q., Gao, Y., Gu, X., \& Yang, Z. (2007). Use of bentonite to control the release of copper from contaminated soils. Australian Journal of Soil Research, 45(8), 618-623. http://dx.doi.org/10.1071/SR07079.

Ministry of Environment (MOEN) (2008). Oil spill logbook investigated (pp. 10). Ministry of Environment, Bayelsa state, Nigeria.

Nduka, J. K., Obumselu, F. O., \& Umedun, N. L. (2012). Crude oil and fractional spillages resulting from exploration and exploitation in Niger-Delta region of Nigeria: A review about the environmental and public health impact. In M. Younes (Ed.) Crude oil exploration in the world.

Ngobiri, C. N., \& Ayuk, A. A. (2007). Anunuso II. Differential degradation of hydrocarbon fractions during bioremediation of crude oil polluted sites in Niger Delta area. Journal of Chemical Society of Nigeria, 32, 151158.

Nolan, K. (2003). Copper Toxicity Syndrome. J. Orthomol. Psychiatry, 12(4), 270-282.

Odu, C. T. I., Nwoboshi, L. C., \& Esuruoso, O. F. (1985). Environmental studies (soils and vegetation) of the Nigerian Agip Oil Company Operation Industry and the Nigerian Environment (pp. 274-283). Lagos, Nigeria: NNPC.

Osuji, L. C., \& Nwoye, S. C. (2007). An appraisal of the impact of petroleum hydrocarbons on soil fertility: the Owaza experience. African Journal of Agricultural Research, 2(7), 318-324.

Ozurumba, C. C. (1999). Effects and causes of oil spillage. National Association of Petroleum Explorationist Bulletin, 14, 31-45.

Sauve, S., McBride, M. B., Norvell, W. A., \& Hendershot, W. H. (1997). Copper solubility and speciation of in situ contaminated soils: Effects of copper level, $\mathrm{pH}$ and organic matter. Water, Air and Soil Pollution, 100, 133149.

http://dx.doi.org/10.1023/A:1018312109677.

State Environmental Protection Administration of China (SETAC). (1995). Chinese Environmental Quality Standard for Soils (GB15618-1995). Beijing, China: author.

Varun, M., D’Souza, V., Pratas, J., \& Paul, M. S. (2012). Metal contamination of soils and plants associated with the glass industry in north central India: prospects of phytoremediation. Environmental Science and Pollution Research, 19, 269-281. http://dx.doi.org/10.1007/s11356-011-0530-4.

World Health Organization (WHO). (1996). Permissible limit of heavy metals in soil and plants. Geneva, Switzerland: author.

Young, R. A. (2005). Toxicity Profiles: Toxicity Summary for Cadmium, Risk Assessment Information System.
RAIS, University of Tennessee Retrieved from: http://rais.ornl.gov/tox/profiles/cadmium.html. 


\title{
Dirvožemio taršos metalais ir diagnostinių biologinių rūšių, susijusių su naftos išsiliejamais ịvertinimas Nigerio deltoje, Nigerijoje
}

\author{
Paul O. Fatoba, Clement O. Ogunkunle ir Cynthian O. Ihaza \\ Aplinkos biologijos skyrius, Augaly biologijos departamentas, Ilorin universitetas, Nigerija
}

(gauta 2015 m. birželio mèn.; priimta spaudai 2015 m. liepos mėn.)

\begin{abstract}
Šiame tyrime buvo įvertintas žaliavinès naftos išsiliejimų ekologinis poveikis aplinkai Nigerijos Nigerio deltos bendruomeneje, kurioje gausu naftos išteklių. Buvo paimti viršutinio dirvožemio $(0-15 \mathrm{~cm})$, vidutinio dirvožemio $(15-25 \mathrm{~cm})$ ir vyraujančių rūšių - Gamba žolès (Andropogon gayanus) - bandiniai, naudojant skersinio pjūvio metodą tuose taškuose, kuriuose buvo išsiliejusi nafta. Bandiniai taip pat buvo paimti iš nepaveiktų vietų (kontrolei). Bandiniai buvo šlapiai kompostuojami ir buvo nustatytos $\mathrm{Pb}, \mathrm{Cd}, \mathrm{Cu}$ ir $\mathrm{Zn}$ koncentracijos, naudojant liepsnos atominę absorbcijos spektrometriją, o viršutinio dirvožemio fiziko-cheminès savybès buvo nustatytos standartiniais metodais. Informacija buvo panaudota Studento t-testui, ANOVA ir Pearsono koreliacijos analizei atlikti, o taršos įvertinimo modeliai buvo panaudoti nustatyti dirvožemio ir augalų rūšių taršos dydį. Rezultatai parodè, kad $\mathrm{Pb}, \mathrm{Cu}$ ir $\mathrm{Zn}$ koncentracijos viršutiniame dirvožemyje viršijo tarptautinius standartus netoli išsiliejimų esančiose vietose $(0-200 \mathrm{~m})$, o Cd koncentracijos tarptautinius standartus viršijo visose vietose. Vidutiniame dirvožemyje tarptautinius standartus viršijo tik $\mathrm{Cd}$. Užterštumo $\left(P_{i}\right)$ ir Integruotos taršos $\left(P_{c}\right)$ viršutinio dirvožemio rodikliai parodè mažèjančią tendenciją: taršos vietose $(0-100 \mathrm{~m})$ buvo didelè $P_{c}$, o $200 \mathrm{~m}$ atstumtu - visų metalų $P_{c}$ buvo vidutinè. $\mathrm{Pb}$ ir Cd dydžiai diagnostinèse biologinėse rūšyse viršijo Pasaulinès Sveikatos organizacijos standartus ir Taršos apkrovos rodiklis (PLI) parode didelę taršą. Apibendrinant, žaliavinès naftos išsiliejimų poveikis buvo žymus, todèl dirvožemio sutvarkymas yra svarbus, kad būtų išvengta ekologinès ir žmonių sveikatos katastrofos. Be to, šios išvados yra naudingos projektuojant vietos aplinkos kontrolei skirtoms strateginėms priemonėms.

Raktiniai žodžiai: naftos išsiliejimas, integruotas taršos rodiklis, dirvožemio sutvarkymas, taršos apkrovos rodiklis.
\end{abstract}




\title{
Comparison and Suitability of SRTM and ASTER Digital Elevation Data for Terrain Analysis and Geomorphometric Parameters: Case Study of Sungai Patah Subwatershed (Baram River, Sarawak, Malaysia)
}

\author{
H Vijith, LW Seling, and D Dodge-Wan \\ Department of Applied Geology, Faculty of Engineering and Science, Curtin University, Miri, Sarawak, \\ Malaysia \\ Corresponding author: \\ $H$ Vijith, Department of Applied Geology, Faculty of Engineering and Science, Curtin University, Sarawak \\ Campus, CDT 250, 98009 Miri, Sarawak, Malaysia \\ Email:vijith.hamza@curtin.edu.my(vijithh@gmail.com)
}

(received in June 2015; accepted in July 2015)

\begin{abstract}
Determination of suitability of satellite-derived elevation data sets in terrain characterisation in a tropical region was carried out on the Sungai Patah subwatershed in the interior of Sarawak, East Malaysia. The goal was to facilitate rapid assessment of topographic variables and spatial parameters related to the morphometric aspects of the region. The freely available SRTM (90 m) and ASTER $(30 \mathrm{~m})$ elevation data sets were compared and used to generate spatial and aspatial parameters. The cross-validation of SRTM and ASTER elevation surfaces with toposheet-derived elevation for 200 random points shows root mean squared errors (RMSE) of $\pm 35.08 \mathrm{~m}$ and $\pm 44 \mathrm{~m}$, respectively. The spatial and aspatial parameters derived show certain major and minor variations in the outputs, which can be attributed to the differences in spatial and spectral resolutions of the data acquisition systems. The results and the findings of the present study suggest that both SRTM and ASTER elevation data sets can be used for terrain characterisation in regions similar to the study area, by replacing the traditional toposheet-derived elevation surfaces. However, minor errors are present when either set is used independently. This can be avoided by the concurrent use of SRTM and ASTER elevation data sets, which will reduce data errors and artefacts in both data sets and improve the accuracy of terrain variables and watershed parameters derived from them.
\end{abstract}

Keywords: SRTM, ASTER, DEM, geomorphometry, hypsometry.

\section{Introduction}

The elevation of an area, which controls the hydrological, geomorphological and evolutional characteristics of the region, has significant importance in the field of geomorphic analysis. Spatial variation in the relief of an area makes it more exposable and vulnerable to denudational processes, which operate in the region. In order to estimate reliefrelated parameters in shaping the surface and controlling the processes that operate, it is necessary to have good quality, high-resolution elevation data sets. In general, toposheet-contour-derived elevation data have been used conventionally for assessing the relief parameters. This may be more erroneous because accuracy depends on the capability of the analyst who generates the data sets. This can be overcome by replacing the conventional toposheetderived data sets by satellite-derived digital elevation models (DEMs). Satellite-derived digital elevation models, along with the advancement in the geographical information systems (GIS), have enabled rapid progress in the field of geomorphometric analysis at varying scales and ranges (Zomer, Ustin, \& Ives, 2002; Hilton, Featherstone, Berry, Johnson, \& Kirby, 2003; Kamp, Tobias, \& Jeffrey, 2005; Prasannakumar, Shiny, Geetha, \& Vijith, 2011; Cook, Murray, Luckman, Vaughan, \& Barrand, 2012; Czubski, Kozak, \& Kolecka, 2013; Jozsa, Fabian, \& Kovacs, 2014). A number of studies have been 
reported on the application of satellite-derived digital elevation models in various fields like morphometric analysis, hydrogeology, soil erosion mapping, slope management, flood plain delineations and regional neotectonic analysis (Kervyn, Ernst, Goosens, \& Jacobs, 2008; Henkel et al. 2010; Hosseinzadeh, 2011; Sleszynski, 2012; Saleem, 2013). Most of the studies have used high ground resolution data sets $(10 \mathrm{~m}$ or less) for detailed assessment of terrain characteristics for local large-scale studies. The freely available moderate resolution data sets $(\geq 30 \mathrm{~m})$ have been used for regional studies. Due to the increased availability of free, moderate resolution and highly accurate digital elevation models, many regional studies derive major elevation parameters from these sources only. The most commonly used free elevation data sets are derived from Shuttle Radar Topographic Mission (SRTM) and Advanced Spaceborne Thermal Emission and Reflection Radiometer (ASTER) with a ground resolution of $90 \mathrm{~m}$ and $30 \mathrm{~m}$, respectively, and a vertical accuracy of $\pm 17 \mathrm{~m}$ (Rodriguez et al., 2005; Tachikawa et al., 2011).

The present study was framed with an objective of determining the usefulness of freely available digital elevation models, for generating and analysing the topographic parameters for terrain characterisation in the interior region of Sarawak, Malaysia. Determination of the best suitable satellite-derived DEM will accelerate scientific studies in the region in the fields of soil erosion, landslide modelling, morphotectonic analysis and drainage basin characterisation, because local and regional scale studies based on such data sets are currently absent. Hence, in the present study, a highly undulating area in the interior of the Baram river basin (Northern Borneo) was selected and the SRTM and ASTER elevation surface-derived terrain characteristics were cross compared and evaluated.

\section{Materials and methods \\ 2.1 Study area}

The Sungai Patah subwatershed study area is one of the major subwatersheds of the Baram River, the second largest river in Sarawak (Northern Borneo, Malaysia). The subwatershed is elongated and has a total area of $1029 \mathrm{~km}^{2}$. It extends between latitude $3^{\circ}$ $20^{\prime} 23^{\prime \prime}$ to $3^{\circ} 41^{\prime} 45^{\prime \prime} \mathrm{N}$ and longitude $114^{\circ} 35^{\prime} 17^{\prime \prime}$ to $115^{\circ} 9$ ' $58^{\prime \prime} \mathrm{E}$ (Figure 1). The elevation of the area varies from approximately $20 \mathrm{~m}$ to above $1,500 \mathrm{~m}$ above the sea level and exhibits varying landforms of highly undulating nature. The drainage pattern in the Sungai Patah subwatershed is dendritic to trellis. Geologically the area is composed of intensely folded sediments and meta-sediments of 3 different ages: Palaeocene deep water sediments, Oligocene sediments, and Miocene sediments, with Oligocene sediments being predominant. The tropical area receives high average annual rainfall in excess of $4500 \mathrm{~mm}$ and average minimum and maximum temperatures of $20^{\circ} \mathrm{C}$ to $30^{\circ} \mathrm{C}$, respectively.
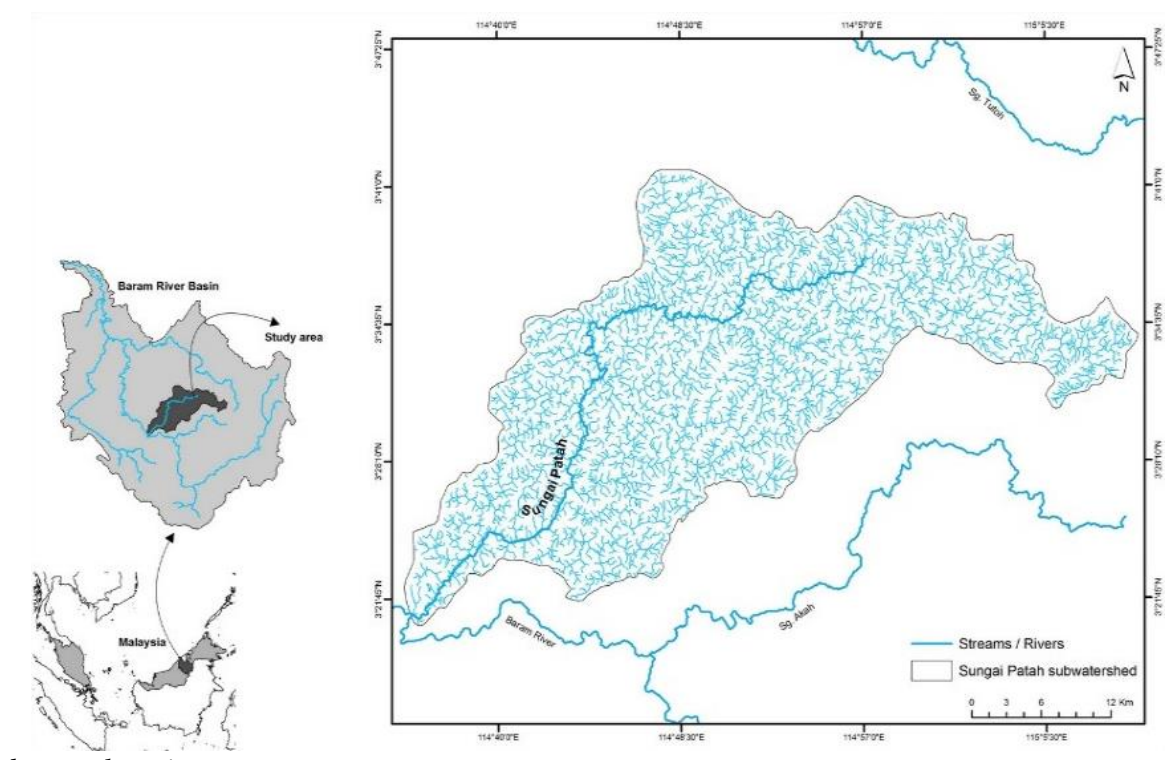

Figure 1. Study area location map.

\subsection{Elevation data sources \\ 2.2.1 Shuttle Radar Topography Mission (SRTM) data}

A space shuttle based mission, jointly operated by the space agencies in the USA, Germany and Italy, aimed to map and generate elevation surface details of the globe between $\pm 60^{\circ}$ and covered $80 \%$ of the total globe in 10 days in February 2000 (Farr, \& Kobrick, 2000; Werner, 2001; Smith, \& Sandwell, 2003; Rabus, Eineder, Roth, \& Bamler, 2003; Farr et al., 2007). In the present study, the latest version of SRTM data (version 4.1), available in the CGIAR consortium for spatial information (http://www.cgiar-csi.org) with a ground resolution of $90 \mathrm{~m}$, was downloaded and analysed. In this version, maximum errors have been removed and data gaps have been filled using auxiliary data sets in order to provide better horizontal and absolute vertical accuracy of $8.8 \mathrm{~m}$ and $6.2 \mathrm{~m}$ fat a confidence level of $90 \%$ for the study region (http://www.cgiar-csi.org). 


\subsubsection{Advanced Spaceborne Thermal Emission and Reflection Radiometer (ASTER) data}

Another mission, which was jointly conducted by NASA and Japan Ministry of Economy Trade and Industry (METI), using the Terra spacecraft, started collecting data of the earth surface and other atmospheric parameters in February 2000, using its 5 on-board remote sensors (GLCF, 2004). ASTER has the capability of off-nadir views $\left( \pm 27^{\circ}\right)$, which facilitate stereoscopic observation with a $30 \mathrm{~m}$ ground resolution. More details about the mission and data sets can be found in Abrams, Hook, \& Ramachandran, 2002. The ASTER Global Digital Elevation Model (GDEM) generated from this data set is freely available from the website of Japan Space Agency since June 2009 (http://gdem.ersdac.jspacesystems. or.jp). In the present study, ASTER GDEM version 2 was used. It has horizontal and vertical accuracy of $8.68 \mathrm{~m}$ and $17.01 \mathrm{~m}$ at a confidence level of $95 \%$ (Tachikawa et al., 2011).

\subsection{Methodology}

Before generating terrain variables and morphometric parameters from the SRTM and ASTER DEMs, both data sets were cross-compared with toposheet-derived $(1: 50,000)$ elevation data through 2 different kinds of analysis. In the first approach, random point elevation cross matching and, in the second approach, unique area based comparison of statistical parameters were carried out. Following the direct comparison of SRTM and ASTER data sets with the toposheet-derived elevation surface, a number of spatial and aspatial (geomorphometric) parameters were then derived from both DEMs for the Sungai Patah subwatershed. Derived spatial parameters are slope, slope aspect, and relative relief. The calculated aspatial parameters are standard geomorphometric parameters (linear, relief, and aerial parameters), and the detailed methodology adapted for the calculation is given in Table 1 .

Table 1. Formulae used for computation of morphometric parameters with references.

\begin{tabular}{|c|c|c|c|}
\hline \multicolumn{2}{|c|}{ Morphometric parameter } & \multirow{2}{*}{$\begin{array}{c}\text { Formula } \\
\text { Total area contributing }\end{array}$} & \multirow[t]{2}{*}{ Reference } \\
\hline & Area $\left(\mathrm{km}^{2}\right)-(\mathrm{A})$ & & \\
\hline & Perimeter $(\mathrm{km})-(\mathrm{P})$ & $\begin{array}{l}\text { The outer boundary of the watershed } \\
\text { that enclosed its area }\end{array}$ & \\
\hline \multirow[t]{8}{*}{ Linear } & Stream Order - $(\mathrm{U})$ & Hierarchical rank & Strahler $(1952,1964)$ \\
\hline & Number of Segments $-\left(\mathrm{N}_{\mathrm{u}}\right)$ & $\mathrm{N}_{\mathrm{u}}=\mathrm{N}_{1}+\mathrm{N}_{2}+\ldots \ldots+\mathrm{N}_{\mathrm{n}}$ & Horton (1945) \\
\hline & Stream Length $(\mathrm{m}$ or $\mathrm{km})-(\mathrm{Lu})$ & $\mathrm{L}_{\mathrm{u}}=\mathrm{L}_{1}+\mathrm{L}_{2}+\ldots \ldots+\mathrm{L}_{\mathrm{n}}$ & Horton (1945) \\
\hline & Mean Stream Length - $\left(\mathrm{L}_{\mathrm{sm}}\right)$ & $\mathrm{L}_{\mathrm{sm}}=\mathrm{Lu} / \mathrm{N}_{\mathrm{u}}$ & Strahler (1964) \\
\hline & Stream Length Ratio - $\left(\mathrm{R}_{\mathrm{L}}\right)$ & $\mathrm{R}_{\mathrm{L}}=\mathrm{L}_{\mathrm{u}} / \mathrm{L}_{\mathrm{u}}-1$ & Horton (1945) \\
\hline & Bifurcation Ratio $-\left(\mathrm{R}_{\mathrm{b}}\right)$ & $\mathrm{R}_{\mathrm{b}}=\mathrm{N}_{\mathrm{u}} / \mathrm{N}_{\mathrm{u}}+1$ & Schumm (1956) \\
\hline & Mean Bifurcation Ratio - $\left(\mathrm{R}_{\mathrm{bm}}\right)$ & Average of $\mathrm{R}_{\mathrm{b}}$ & Strahler (1964) \\
\hline & RHO coefficient $-(\rho)$ & $\rho=R_{L} / R_{b}$ & Horton (1945) \\
\hline \multirow[t]{3}{*}{ Relief } & Basin Relief $-\left(\mathrm{B}_{\mathrm{h}}\right)$ & $\mathrm{B}_{\mathrm{h}}=\mathrm{H}-\mathrm{h}$ & Hardely and Schumm (1961) \\
\hline & Relief Ratio $R_{h}$ & $\mathrm{R}_{\mathrm{h}}=\mathrm{B}_{\mathrm{h}} / \mathrm{L}_{\mathrm{b}}$ & Schumm (1963) \\
\hline & Ruggedness number $\mathrm{R}_{\mathrm{n}}$ & $\mathrm{R}_{\mathrm{n}}=\mathrm{R}_{\mathrm{h}} * \mathrm{D}_{\mathrm{d}}$ & Patton and Baker (1976) \\
\hline \multirow[t]{9}{*}{ Aerial } & Drainage Density $\mathrm{D}_{\mathrm{d}}$ & $\mathrm{D}_{\mathrm{d}}=\mathrm{Lu} / \mathrm{A}$ & Horton $(1932,1945)$ \\
\hline & Stream Frequency $\mathrm{F}_{\mathrm{s}}$ & $\mathrm{F}_{\mathrm{s}}=\mathrm{N}_{\mathrm{u}} / \mathrm{A}$ & Horton (1932) \\
\hline & Texture Ratio T & $\mathrm{T}=\mathrm{N}_{1} / \mathrm{P}$ & Horton (1945) \\
\hline & Form Factor $\mathrm{R}_{\mathrm{f}}$ & $\mathrm{R}_{\mathrm{f}}=\mathrm{A} / \mathrm{Lb}^{2}$ & Horton (1945) \\
\hline & Circulatory Ratio $\mathrm{R}_{\mathrm{c}}$ & $\mathrm{R}_{\mathrm{c}}=4^{*} \pi^{*} \mathrm{~A} / \mathrm{P}^{2}$ & Miller (1953) \\
\hline & Elongation Ratio $\mathrm{R}_{\mathrm{e}}$ & $\mathrm{R}_{\mathrm{e}}=1.128 * \sqrt{\mathrm{A} / \mathrm{Lb}}$ & Schumm (1956) \\
\hline & Constant Channel Maintenance C & $\mathrm{C}=1 / \mathrm{D}_{\mathrm{d}}$ & Schumm (1956) \\
\hline & Length of overland flow $\mathrm{Lg}$ & $\mathrm{Lg}_{\mathrm{g}}=1 / 2 \mathrm{D}_{\mathrm{d}}$ or $\mathrm{C} / 2$ & Horton (1945) \\
\hline & Shape Index $S_{w}$ & $S_{\mathrm{w}}=1 / \mathrm{R}_{\mathrm{f}}$ & Horton (1945) \\
\hline $\begin{array}{c}\text { Elevation - } \\
\text { Area } \\
\end{array}$ & $\begin{array}{c}\text { Hypsometric curve } \\
\text { Hypsometric integral }\left(\mathrm{I}_{\text {hyp }}\right) \\
\end{array}$ & $\begin{array}{c}\text { Graph: } \mathrm{h} / \mathrm{H} \text { against a/A } \\
\mathrm{I}_{\text {hyp }}=\left(\mathrm{h}_{\text {mean }}-\mathrm{h}_{\min }\right) /\left(\mathrm{h}_{\max }-\mathrm{h}_{\min }\right)\end{array}$ & Strahler (1952) \\
\hline
\end{tabular}

where $N_{l}=$ Number of segments in particular order, $L_{u^{-}}-1=$ stream length of next lower order, $N_{u}+1=$ number of streams in next higher order, $H=$ maximum height of the basin, $h=$ minimum height of the basin, $L b=$ basin length, $\Pi=3.14, h / H=$ proportion of the total height, a/A = proportion of the total area, $H=$ total relative height, $A=$ total area of the basin, $a=$ area of the basin above a given line of elevation $h, h_{\text {mean }}=$ average height of the area, $h_{\text {max }}=$ maximum height of the area, $h_{\text {min }}$ = minimum height of the area

Two other important geomorphometric parameters, i. e., hypsometric curve and integral and longitudinal profile, which ultimately help to characterise and classify the watershed, were also derived from both DEMs. The successful extraction of these parameters from the DEMs will facilitate the rapid analysis and interpretation of terrain variables by substituting the traditional topographic-sheet-derived contour-based analysis of terrain parameters. 


\section{Results and discussion}

3.1 Cross validation of SRTM and ASTER DEMS with toposheet-derived elevation surface

Two approaches were taken to compare and validate data quality and error factors associated with the data sets before deriving and analysing morphometric parameters for the Sungai Patah subwatershed. In the first approach for the whole area, a random point generation method was used in which a total of 200 points were generated and elevation values corresponding to each point were extracted from the toposheets, SRTM and ASTER digital elevation surfaces (Figure 2).

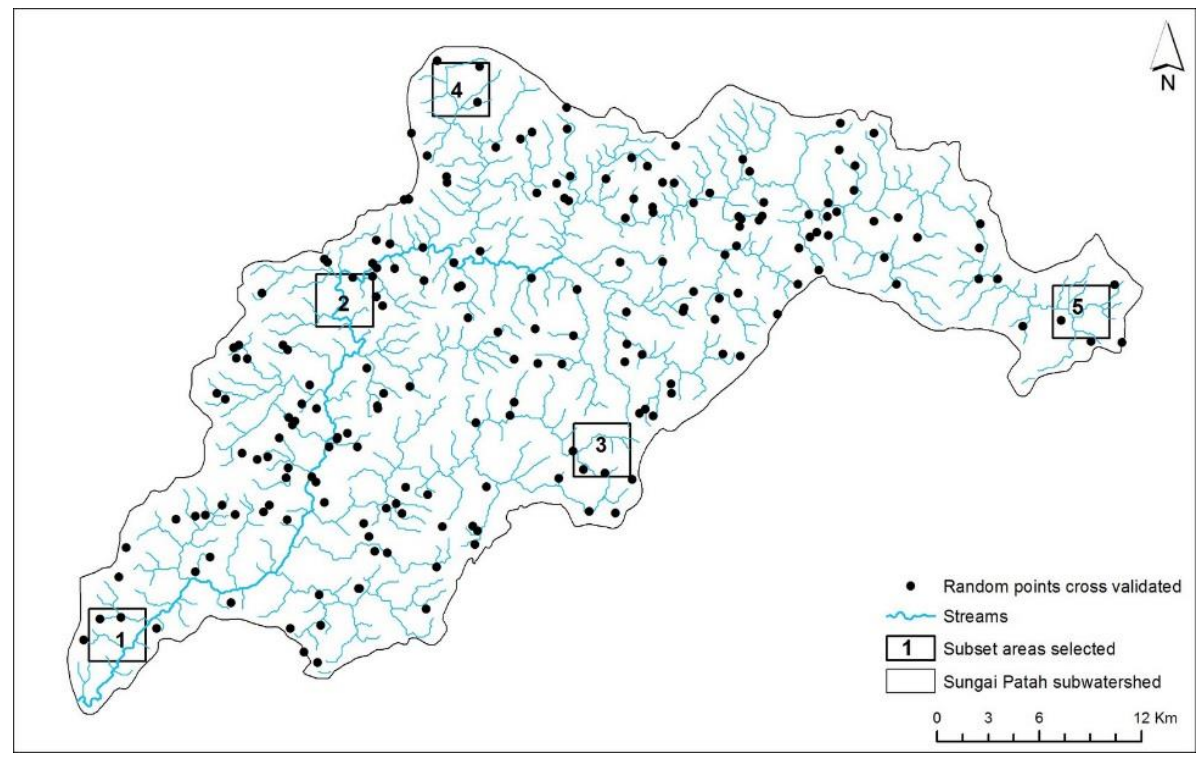

Figure 2. Cross-validation points and sample areas selected.

The mean elevation for the 200 points was found to be $427.8 \mathrm{~m}, 430.74 \mathrm{~m}$, and $424.2 \mathrm{~m}$, respectively. Although the mean elevations differed by only a few meters for a very small number of sampling points, differences of up to approximately $150 \mathrm{~m}$ were found.

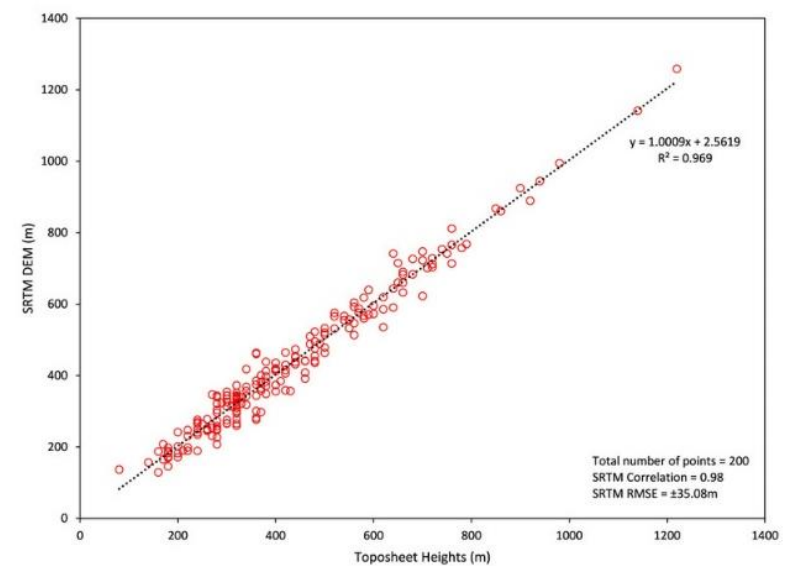

Elevation values derived from the toposheets were plotted against the SRTM and ASTER elevation values, which indicated a good correlation with correlation coefficient of $r=0.98$ and $r=0.97$, respectively (Figure 3).

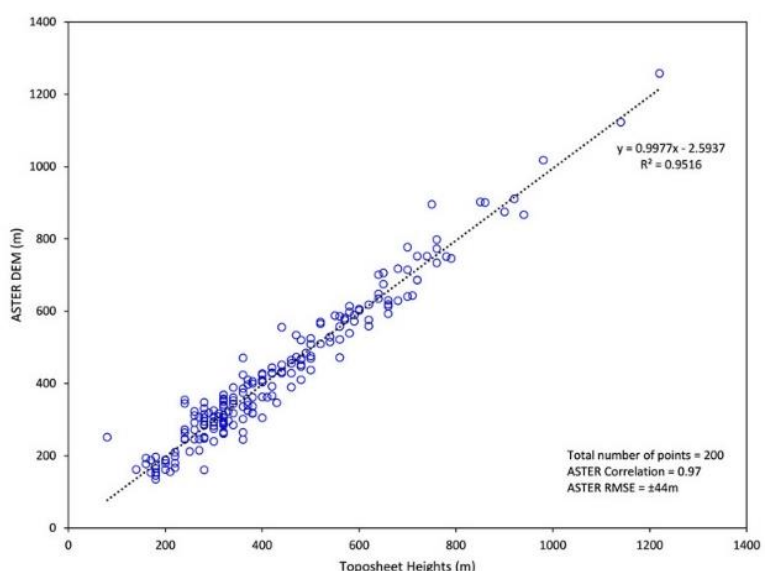

Figure 3. Correlation plots of common random points selected from SRTM and ASTER DEMs against toposheet elevation showing RMSE of $\pm 35.08 \mathrm{~m}$ and $\pm 44 \mathrm{~m}$, respectively.

The average elevation residual values for both data sets were found to be in the range of $\pm 3 \mathrm{~m}$ (SRTM) to $\pm 4 \mathrm{~m}$ (ASTER) when compared with the toposheet-derived elevation points; however, the root mean square error of the compared data sets was $\pm 35.08 \mathrm{~m}$ and $\pm 44 \mathrm{~m}$. In the second approach, 5 distinct areas of uniform size $\left(10 \mathrm{~km}^{2}\right)$ were selected from the study area (at varying elevations and terrain conditions), the DEMs were clipped and the data for the 5 subsets were analysed statistically. Though the spatial resolutions of the DEMs are varying, the results of the statistical analysis show certain similarities and are given in the Table 2. The general statistical parameters, such as minimum, maximum, mean, and standard deviation of these selected subsets, are comparable, generally differing by less than $40 \mathrm{~m}$, while the RMSE is quite variable, ranging from $\pm 10.81 \mathrm{~m}$ to $\pm 68.81 \mathrm{~m}$, with an average RSME of $\pm 29.73 \mathrm{~m}$. These findings support the choice of using SRTM and ASTER elevation data sets instead of toposheet-derived elevation surface in the present analysis. 
Table 2. Comparison of selected statistics of topo, SRTM and ASTER DEMs.

\begin{tabular}{||c|c|c|c|c|c|c||}
\hline & DEM & Min & Max & Mean & STD & RMSE \\
\hline Subset 1 & Topo & 80 & 460 & 228.5 & 96.3 & \\
\cline { 2 - 7 } & SRTM & 61 & 494 & 237.1 & 97.8 & \pm 27.54 \\
\cline { 2 - 7 } & ASTER & 33 & 493 & 234.3 & 99.0 & \pm 40.61 \\
\hline Subset 2 & Topo & 120 & 320 & 205.4 & 49.8 & \\
\cline { 2 - 7 } & SRTM & 123 & 335 & 205.4 & 43.9 & \pm 10.81 \\
\cline { 2 - 7 } & ASTER & 24 & 336 & 197.2 & 51.9 & \pm 68.81 \\
\hline Subset 3 & Topo & 400 & 1000 & 631.6 & 127.1 & \\
\cline { 2 - 7 } & SRTM & 424 & 1004 & 645.1 & 117.0 & \pm 17.20 \\
\cline { 2 - 7 } & ASTER & 400 & 1020 & 663.5 & 120.4 & \pm 14.14 \\
\hline Subset 4 & Topo & 280 & 900 & 570.7 & 136.4 & \\
\cline { 2 - 7 } & SRTM & 292 & 938 & 590.3 & 137.5 & \pm 28.17 \\
\cline { 2 - 7 } & ASTER & 247 & 937 & 568.3 & 142.9 & \pm 35.05 \\
\hline Subset 5 & Topo & 680 & 1140 & 818.9 & 93.81 & \\
\cline { 2 - 7 } & SRTM & 648 & 1160 & 815.5 & 100.3 & \pm 26.68 \\
\cline { 2 - 7 } & ASTER & 598 & 1140 & 802.7 & 100.9 & \pm 57.98 \\
\hline \hline
\end{tabular}

\subsection{Spatial parameters}

The spatial parameters, such as slope, slope aspect, and relative relief, which play a major role in the analysis of hydrological and denudational processes, were generated and evaluated for the study area using ArcGIS software. The comparison of SRTM- and ASTER-derived elevation surface reveals differences in the minimum and the maximum values and spatial distributions. For the Sungai Patah subwatershed, the elevations derived from SRTM range from $43 \mathrm{~m}$ to $1,530 \mathrm{~m}$, while those derived from ASTER have a greater range from $11 \mathrm{~m}$ to $1,566 \mathrm{~m}$ (Figure $4 \mathrm{a}, 4 \mathrm{~b}$ ). The variation in the basic statistical parameters such as mean and standard deviation for both data sets is within the tolerable limit and varies in between \pm 1 to \pm 5 . Both DEMs show a highly developed fluvial network with some isolated residual hills.

In mountainous terrains, most of the denudational processes are related to the action of flowing water and controlled by the terrain slope (Anbalagan, 1992; Vijith, Krishnakumar, Pradeep, Ninu Krishnan, \& Madhu, 2013). Slope of the area plays a major role in hydrogeology, soil erosion, landslide and other related geo-environmental parameters and processes. Figures $4 \mathrm{c}$ and $4 \mathrm{~d}$ show terrain slopes in the Sungai Patah watershed as derived from the SRTM and ASTER DEMs, respectively. The maximum slope derived from SRTM is $50^{\circ}$, whereas the slope derived from ASTER exceeds $80^{\circ}$. The discrete class analysis of slope surfaces indicates that, for the SRTM-derived slopes, the majority of the pixels $(>83 \%)$ fall in the slope range of $5-25^{\circ}$, where only $64 \%$ of the pixels of the ASTER-derived slopes are in that class range. Over $20 \%$ of the pixels of the ASTER-derived slopes fall in the higher sloping 25$35^{\circ}$ class. Steep sloping areas have higher influence on landslide occurrence and soil erosion and the ASTER data set appears to be the better tool for this sort of analysis as it gives a better representation of steep slopes.

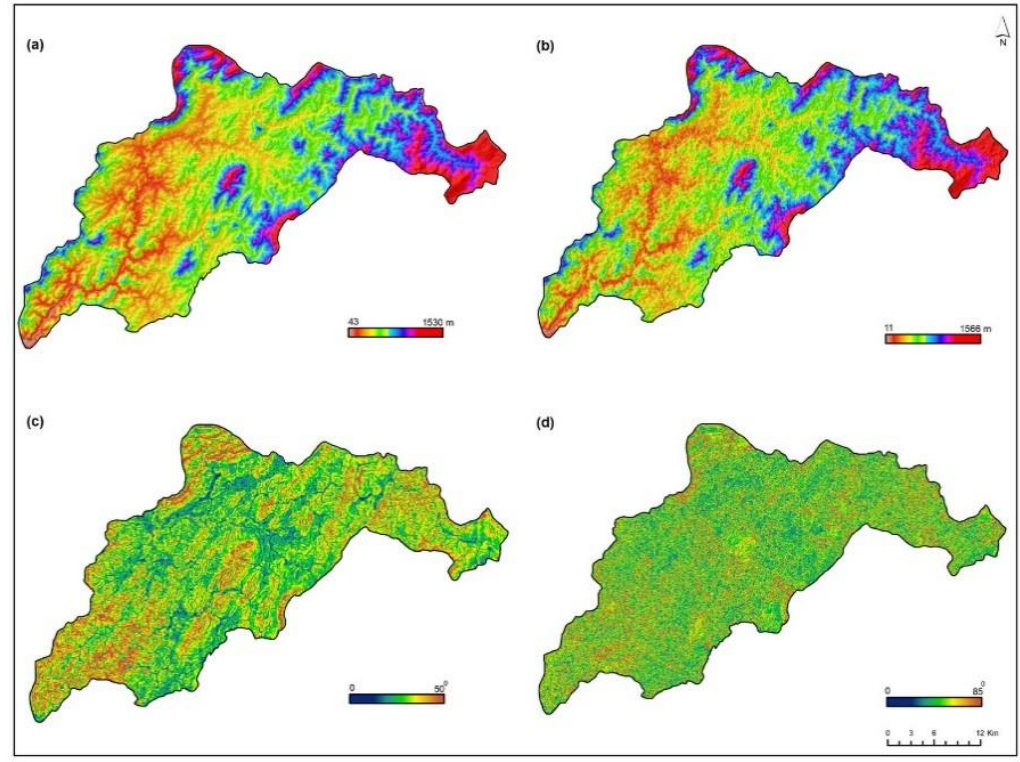

Figure 4. Spatial parameters derived from SRTM and ASTER DEMs. Elevation surfaces: a) SRTM, b) ASTER. Slope: c) SRTM, d) ASTER.

Another parameter considered is slope aspect, the direction towards which the terrain slope faces with respect to the north. This parameter is important as there may be directional influence on terrain 
processes. Generally, the aspect is expressed in compass degrees with the values varying from 0 to $359^{\circ}$ or is designated as -1 for flat areas. The numerical value of the slope aspect may be classified into 8 compass directions (N, NE, E, SE, S, SW, W and NW) or it may be considered flat (no slope aspect). The slope aspect has the potential to influence physical properties of the terrain, such as temperature, moisture, vegetation content, etc., which ultimately influence the susceptibility of the terrain to weathering and erosional process (Rajakumar et al., 2007). The aspect surfaces generated from the SRTM and ASTER DEMs are shown in Figures 5a and 5b, respectively. Both DEMs show similar mean and standard deviation of the slope aspects: the mean of $187.53^{\circ}$ and $182.64^{\circ}$, demonstrating the predominance of south facing slopes, and the standard deviation of $102.16^{\circ}$ and $102.71^{\circ}$, but with significant spatial variation.

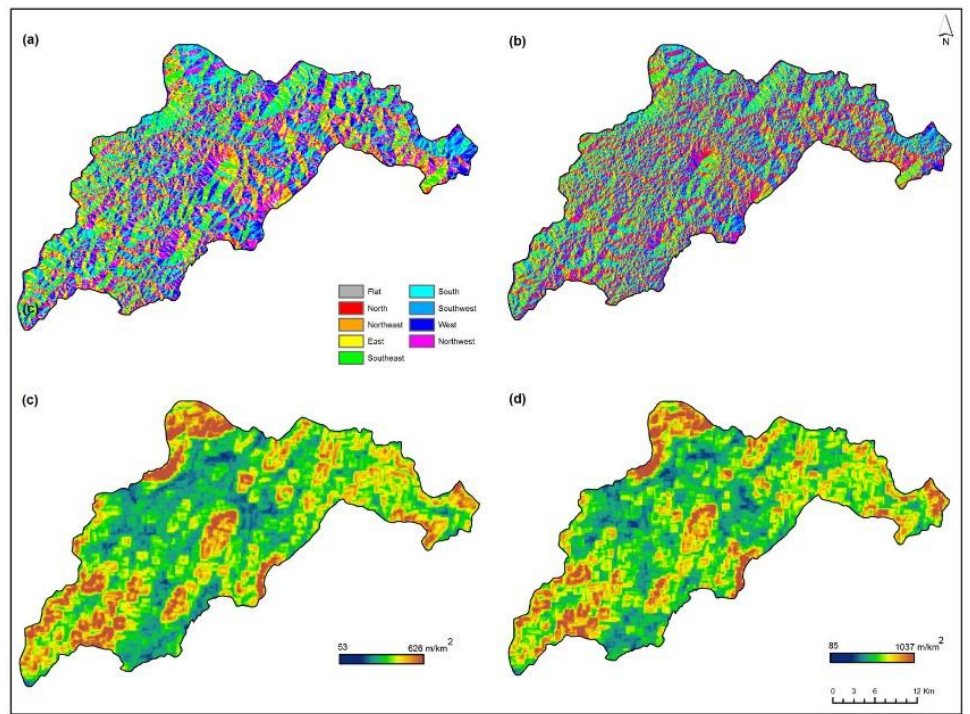

Figure 5. Spatial parameters derived from SRTM and ASTER DEMs. Aspect: a) SRTM, b) ASTER. Relative relief: c) SRTM, d) ASTER.

Relative relief is another parameter of importance in geomorphometric studies and represents the elevation variation per unit area as it influences the down slope movement of sediments and other earth materials and it plays a crucial role in terrain evolution (Vijith, \& Madhu, 2007; Prasannakumar, Shiny, Geetha, \& Vijith, 2011). In order to identify the elevation changes in the Sungai Patah subwatershed per unit area, relative relief maps were calculated from the available SRTM and ASTER elevation surfaces (Figure $5 \mathrm{c}$ and $5 \mathrm{~d}$ ). The relative relief maps, thus, generated from both elevation surfaces show the minimums of $53 \mathrm{~m} / \mathrm{km}^{2}$ and $85 \mathrm{~m} / \mathrm{km}^{2}$, the maximums of $626 \mathrm{~m} / \mathrm{km}^{2}$ and $1037 \mathrm{~m} / \mathrm{km}^{2}$ with means of $225.23 \mathrm{~m} / \mathrm{km}^{2}$ and $273.08 \mathrm{~m} / \mathrm{km}^{2}$ and standard deviations of 81.59 and 85.25, respectively, for SRTM- and ASTER-derived maps. Although the ranges of the relative relief are different between the 2 DEMs, the spatial distribution of the relative relief is remarkably similar. The results show similarity in the spatial pattern with differences in the minimum and the maximum values, which is due to the changes in resolution.

\subsection{Geomorphometric parameters}

Before assessing the geomorphometric parameters from the SRTM and ASTER DEMs, the basic characteristics of the selected subwatershed and streams obtained from these elevation models were cross-compared with those derived from the topographical map. In the present analysis, the subwatershed boundary derived from the topographical map was used to extract the elevation surfaces from the SRTM and ASTER DEMs (because of that the area, perimeter, and basin length were the same). After extracting the study area from the elevation surfaces, the basic parameters needed for the geomorphometric analysis, the stream network with order and length were generated using the ArcHydro extension of ArcGIS 9.3. Table 3 shows the total number of streams, number of first-order streams and order of the subwatershed, assessed from the 3 data sources. While comparing the data, it was noted that the topographic-sheet-derived information was comparable only with the subwatershed order assessed from the ASTER-derived stream networks. A major difference was observed in the total number of streams and the number of first-order streams. However, a common spatial pattern of stream network is observed. The spatial pattern of the stream networks (Figure 6) shows the lateral shift and order variations in the streams derived from both DEMs. The difference in the stream networks derived from the different resolution DEMs demonstrates the sensitivity of the elevation surfaces to the hydrological analysis. The lower ground resolution SRTM data classified the subwatershed as the $5^{\text {th }}$ order, while the ASTERderived stream networks and the topographic sheet both classified it as the $6^{\text {th }}$ order subwatershed. The number of the stream orders and the number of the 
first-order streams are underestimated by the lower ground resolution of the SRTM data.

Table 3. Basic characteristics of drainage networks derived from SRTM and ASTER.

\begin{tabular}{|c|c|c|c|c||}
\hline \hline Data & $\begin{array}{c}\text { Scale or ground } \\
\text { resolution }\end{array}$ & $\begin{array}{c}\text { Total no. of } \\
\text { streams }\end{array}$ & $\begin{array}{c}\text { No. of 1 } \\
\text { streams order }\end{array}$ & $\begin{array}{c}\text { Order of the } \\
\text { subwatershed }\end{array}$ \\
\hline Toposheet & $1: 50,000$ & 3,204 & 1,640 & 6 \\
\hline SRTM & $90 \mathrm{~m}$ & 617 & 316 & 5 \\
\hline ASTER & $30 \mathrm{~m}$ & 4,081 & 2,101 & 6 \\
\hline
\end{tabular}

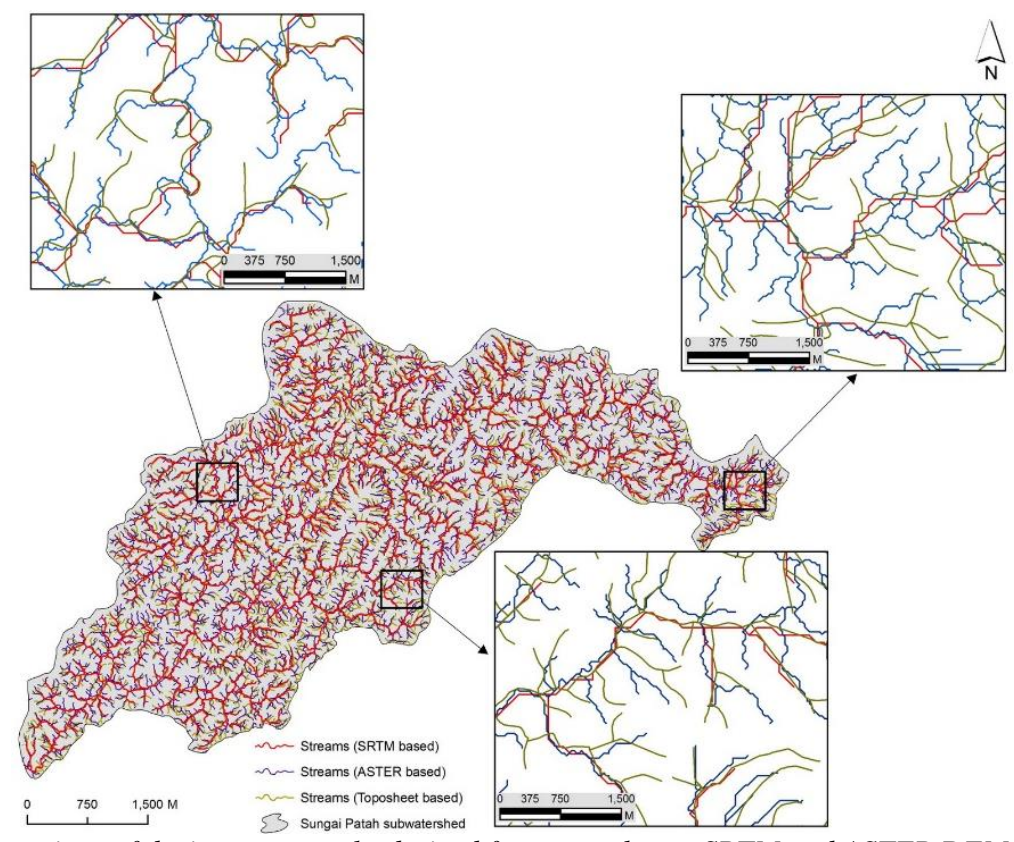

Figure 6. Cross-comparison of drainage networks derived from toposheets, SRTM and ASTER DEMs.

Geomorphometric analyses give insight into the geological, hydrological and topographical characteristics of the area (Strahler, 1952, 1964; Pike, \& Wilson, 1971; Pike, 2000). The analysed geomorphometric parameters based on the standard methods of the calculation given in Table 1, using the stream networks and the elevation values derived from the SRTM and ASTER DEMs, were grouped into the following 4 categories: linear, relief, aerial, and elevation-area parameters; the results are provided in Table 4.

The analysis was started by comparing the subwatershed order, number and length of stream segments of each order. The lower ground resolution SRTM-derived stream network consists of fewer streams (particularly of lower order), with significantly shorter stream length than the higher ground resolution ASTER-derived stream networks. The SRTM-derived stream network shows a total of 617 streams with $5^{\text {th }}$ as the higher order of the stream. The ASTER-derived data show a total of 4,081 stream segments with $6^{\text {th }}$ as the highest order. This difference resulted in the length of each segment and the total length of streams, which vary from $978 \mathrm{~km}$ to $2,416 \mathrm{~km}$, respectively, for SRTM and ASTER derived stream networks. As a result of the discrepancy in the number of segments and stream length, significant differences are also apparent in the mean stream lengths, which are $1.35 \mathrm{~km}$ and $0.52 \mathrm{~km}$, respectively. Other geomorphometric parameters, which are derived from stream length and/or number of segments are also affected, such as stream length ratio (0.84 and 0.59$)$, drainage density (0.95 and $\left.2.35 \mathrm{~km} / \mathrm{km}^{2}\right)$, stream frequency $\left(0.60\right.$ and $\left.3.97 \mathrm{~km}^{2}\right)$, ruggedness number $\left(0.02\right.$ and $\left.0.05 \mathrm{~km} / \mathrm{km}^{2}\right)$, texture ratio $\left(1.55\right.$ and $\left.10.28 \mathrm{~km}^{-1}\right)$ and constant of channel maintenance $(1.05$ and $0.43 \mathrm{~km})$, respectively, for SRTM- and ASTER-derived stream networks. The basin relief was found to be $1,555 \mathrm{~m}$ with the higher resolution ASTER DEM, compared with 1,487 $\mathrm{m}$ for SRTM. Geomorphometric parameters which are not directly derived from stream length and/or number of segments were generally found to be in good agreement between the 2 DEMs. This is the case for mean bifurcation ratio (1.81 for both data sets), Rho coefficient $(0.29$ and 0.31$)$, and relief ratio $(0.0204$ and 0.0214$)$. Other parameters, such as form factor (0.19), circularity ratio (0.31), elongation ratio (0.50), and shape index (5.15) are equivalent for both data sets since they are based on common factors, such as area, perimeter, and basin length. The results obtained for the Sungai Patah case study indicate that both DEMs can be used to derive basic geomorphometric parameters, but those derived from ASTER DEM are closely matched to the toposheet-derived parameters and should be used preferentially where number of segments, stream order, and stream length are critical. Based on the calculated geomorphic parameters, the terrain can be considered as structurally complex, highly dissected and prone to the fluvial erosion process due to high runoff potential. 
Table 4. Geomorphometric parameters calculated for Sungai Patah subwatershed from SRTM and ASTER data sets.

\begin{tabular}{|c|c|c|c|c|c|}
\hline \multirow{4}{*}{$\begin{array}{c}\text { Type of } \\
\text { parameter }\end{array}$} & \multicolumn{2}{|c|}{ Parameters calculated for Sungai Patah } & SRTM & ASTER & \multirow{2}{*}{$\frac{\text { Unit }}{\mathrm{km}^{2}}$} \\
\hline & \multirow{3}{*}{$\begin{array}{l}\text { Common parameters from topographical } \\
\text { sheets ( identical to both data sets)* }\end{array}$} & $\operatorname{Area}(\mathrm{A})^{*}$ & \multicolumn{2}{|r|}{$1,029.24$} & \\
\hline & & Perimeter $(\mathrm{P})^{*}$ & & 204.44 & $\mathrm{~km}$ \\
\hline & & Basin Length (Lb)* & & 72.81 & $\mathrm{~km}$ \\
\hline \multirow{36}{*}{$\begin{array}{c}\text { Linear } \\
\text { parameters }\end{array}$} & \multirow[t]{7}{*}{ No. of segments $(\mathrm{Nu})$} & 1st Order & 316 & 2,101 & No. \\
\hline & & 2nd Order & 129 & 878 & No. \\
\hline & & 3rd Order & 87 & 535 & No. \\
\hline & & 4th Order & 32 & 296 & No. \\
\hline & & 5th Order & 53 & 134 & No. \\
\hline & & 6th Order & - & 137 & No. \\
\hline & & Total & 617 & 4,081 & No. \\
\hline & \multirow[t]{7}{*}{ Stream length $(\mathrm{Lu})$} & 1st Order & 589.37 & $1,415.08$ & $\mathrm{~km}$ \\
\hline & & 2nd Order & 176.32 & 450.51 & $\mathrm{~km}$ \\
\hline & & 3rd Order & 118.25 & 281.42 & $\mathrm{~km}$ \\
\hline & & 4th Order & 29.99 & 139.28 & $\mathrm{~km}$ \\
\hline & & 5th Order & 63.86 & 63.50 & $\mathrm{~km}$ \\
\hline & & 6th Order & - & 66.32 & $\mathrm{~km}$ \\
\hline & & Total & 977.79 & $2,416.12$ & $\mathrm{~km}$ \\
\hline & \multirow[t]{7}{*}{ Mean stream length (Lsm) } & 1st Order & 1.87 & 0.67 & $\mathrm{~km}$ \\
\hline & & 2nd Order & 1.37 & 0.51 & $\mathrm{~km}$ \\
\hline & & 3rd Order & 1.36 & 0.53 & $\mathrm{~km}$ \\
\hline & & 4th Order & 0.94 & 0.47 & $\mathrm{~km}$ \\
\hline & & 5th Order & 1.20 & 0.47 & $\mathrm{~km}$ \\
\hline & & 6th Order & - & 0.48 & $\mathrm{~km}$ \\
\hline & & Average & 1.348 & 0.521 & $\mathrm{~km}$ \\
\hline & \multirow[t]{7}{*}{ Stream length ratio $(\mathrm{RL})$} & 1st Order & - & - & - \\
\hline & & 2nd Order & 0.30 & 0.32 & - \\
\hline & & 3rd Order & 0.67 & 0.62 & - \\
\hline & & 4th Order & 0.25 & 0.49 & - \\
\hline & & 5th Order & 2.13 & 0.46 & - \\
\hline & & 6th Order & - & 1.04 & - \\
\hline & & Average & 0.837 & 0.586 & - \\
\hline & \multirow[t]{6}{*}{ Bifurcation ratio $(\mathrm{Rb})$} & 1st Order & 2.45 & 2.39 & - \\
\hline & & 2nd Order & 1.48 & 1.64 & - \\
\hline & & 3rd Order & 2.72 & 1.81 & - \\
\hline & & 4th Order & 0.60 & 2.21 & - \\
\hline & & 5th Order & - & 0.98 & - \\
\hline & & 6th Order & - & - & - \\
\hline & \multicolumn{2}{|c|}{ Mean bifurcation ratio (Rbm) } & 1.813 & 1.806 & - \\
\hline & \multicolumn{2}{|l|}{ RHO coefficient $(\rho)$} & 0.29 & 0.31 & - \\
\hline \multirow[t]{3}{*}{ Relief parameters } & \multicolumn{2}{|l|}{ Basin relief $(\mathrm{Bh})$} & $1,487.00$ & $1,555.00$ & $\mathrm{~m}$ \\
\hline & \multicolumn{2}{|l|}{ Relief ratio $(\mathrm{Rh})$} & 0.0204 & 0.0214 & - \\
\hline & \multicolumn{2}{|c|}{ Ruggedness number (Rn) } & 0.02 & 0.05 & $\mathrm{~km} / \mathrm{km}^{2}$ \\
\hline \multirow[t]{9}{*}{ Aerial parameters } & \multicolumn{2}{|l|}{ Drainage density $(\mathrm{Dd})$} & 0.95 & 2.35 & $\mathrm{~km} / \mathrm{km}^{2}$ \\
\hline & \multicolumn{2}{|l|}{ Stream frequency $(\mathrm{Fs})$} & 0.60 & 3.97 & $\mathrm{~km}^{-2}$ \\
\hline & Texture ratio $(\mathrm{T})$ & & 1.55 & 10.28 & $\mathrm{~km}^{-1}$ \\
\hline & Form factor $(\mathrm{Rf})^{*}$ & & & 0.19 & - \\
\hline & Circularity ratio (Rc) & & & 0.31 & - \\
\hline & Elongation ratio $(\mathrm{Re})$ & & & 0.50 & - \\
\hline & Constant of channel mainten & ce $(\mathrm{C})$ & 1.05 & 0.43 & $\mathrm{~km}$ \\
\hline & Length of overland flow & & 0.53 & 0.21 & $\mathrm{~km}$ \\
\hline & Shape index $(\mathrm{Sw})^{*}$ & & & 5.15 & - \\
\hline $\begin{array}{c}\text { Elevation-area } \\
\text { parameter }\end{array}$ & Hypsometric integral (I/ & & 27.62 & 28.17 & $\%$ \\
\hline
\end{tabular}

The comparison of area and elevation data of drainage basins provides detailed information about the geomorphic evolutional history and the stages of landscape development. This can be achieved through generation and analysis of hypsometric curve and hypsometric integral, which work on the basis of areaaltitude relationship (Pike, \& Wilson, 1971; Hurtrez,
Sol, \& Lucazeau, 1999; Singh, 2008; Kurse, 2013). Before analysing the hypsometric characteristics of the Sungai Patah subwatershed, a general assessment of area-elevation relationship was carried out by classifying the SRTM and ASTER elevation surfaces into $100 \mathrm{~m}$ elevation classes from 0 to $1400 \mathrm{~m}$ (Figure 7). 


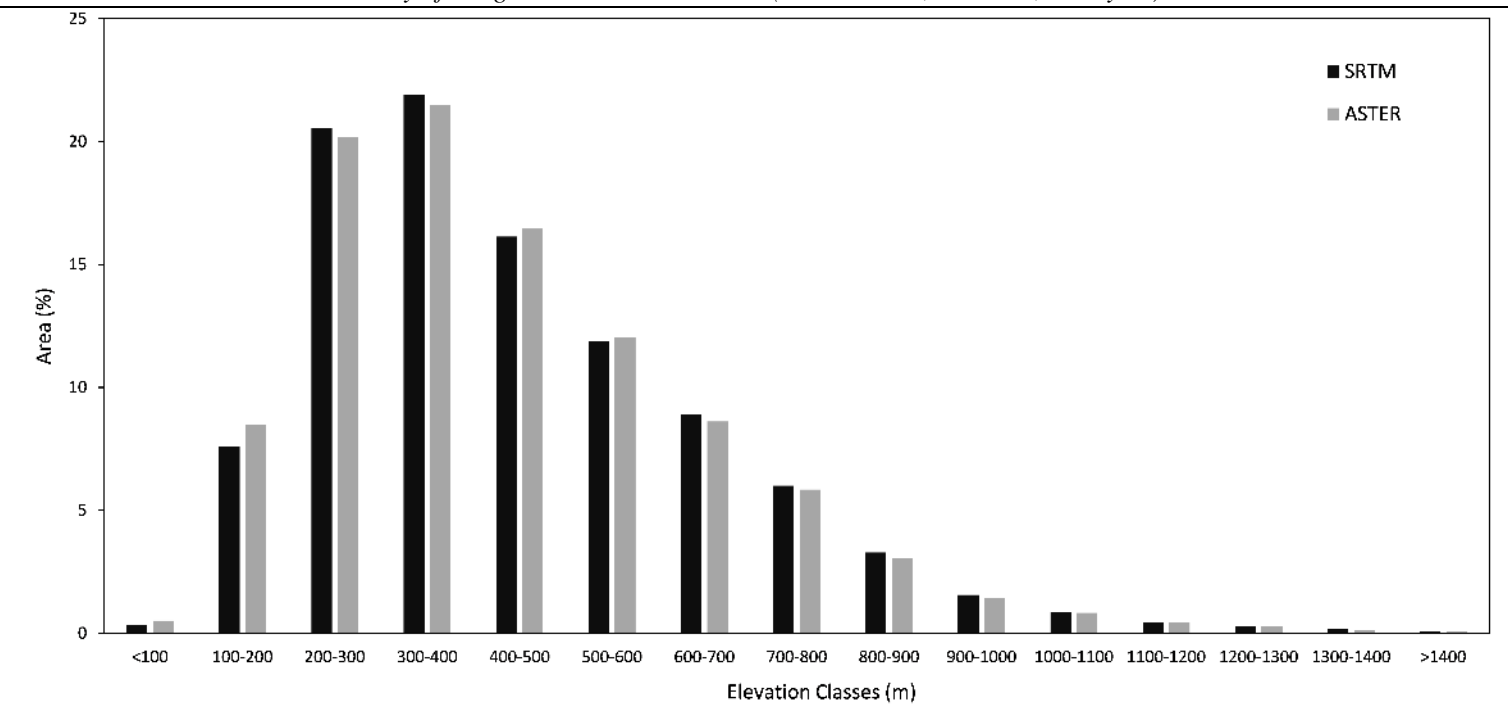

Figure 7. Area-elevation relationship and distribution assessed from SRTM and ASTER DEMs.

It is noted that $70 \%$ of the subwatershed area (>70\%) falls between 200-600 $\mathrm{m}$ for both the SRTM and ASTER elevation surfaces, indicating the usability of both DEMs in terrain analysis. These results facilitated the generation of a hypsometric curve, a non-dimensional area-elevation curve, which allows a ready comparison of catchments with diverse areas by plotting the proportion of the total height $(\mathrm{h} / \mathrm{H})$ against the proportion of the total area $(\mathrm{a} / \mathrm{A})$ of the subwatershed and the hypsometric integral (Ihyp). The hypsometric integral is an indicator of geomorphic maturity (Strahler, 1952). Both SRTM and ASTER DEMs indicate similarly S-shaped hypsometric curves with a concave upward upper region and with very closely matching hypsometric integrals of $0.2762(27.62 \%)$ and $0.2817(28.17 \%)$, respectively (Figure 8).

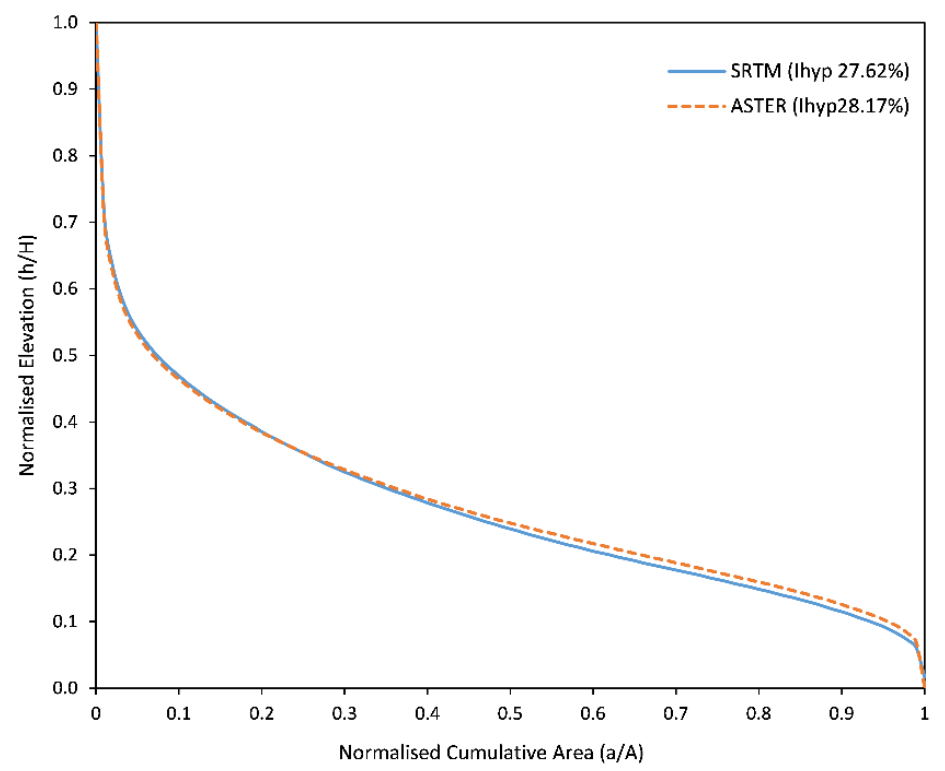

Figure 8. Hypsometric curves and integrals derived for the study area.

The hypsometric integral values are low and this suggests that the Sungai Patah subwatershed drainage basin has reached the old age (monadnocks) stage of evolution (Strahler, 1952). Low hypsometric integrals indicate that fluvial erosion processes operating in a mature fluvial network are dominant over erosive hillslope processes. Both data sets lead to a similar hypsometric integral value and conclusions indicating that they are both suitable in such a kind of analysis.

Another important parameter which can be derived from digital elevation models is a longitudinal profile of streams, which shows altitude against distance and can give insight and real evidence of geological processes operating in watersheds and their influence over river networks (Ferraris, Firpo, \& Pazzaglia, 2012; Giaconia et al., 2012). The longitudinal profile of streams reflects available relief, base level changes (due to tectonic disturbances), and the processes of erosion and deposition (Aiken, \& Brierley, 2013; Ambili, \& Narayana, 2014). In order to generate the longitudinal profile of Sungai Patah, elevation values were extracted from both SRTM and ASTER elevations surfaces for a series of sampling points at a 1-km distance along the stream (Figure 9). 


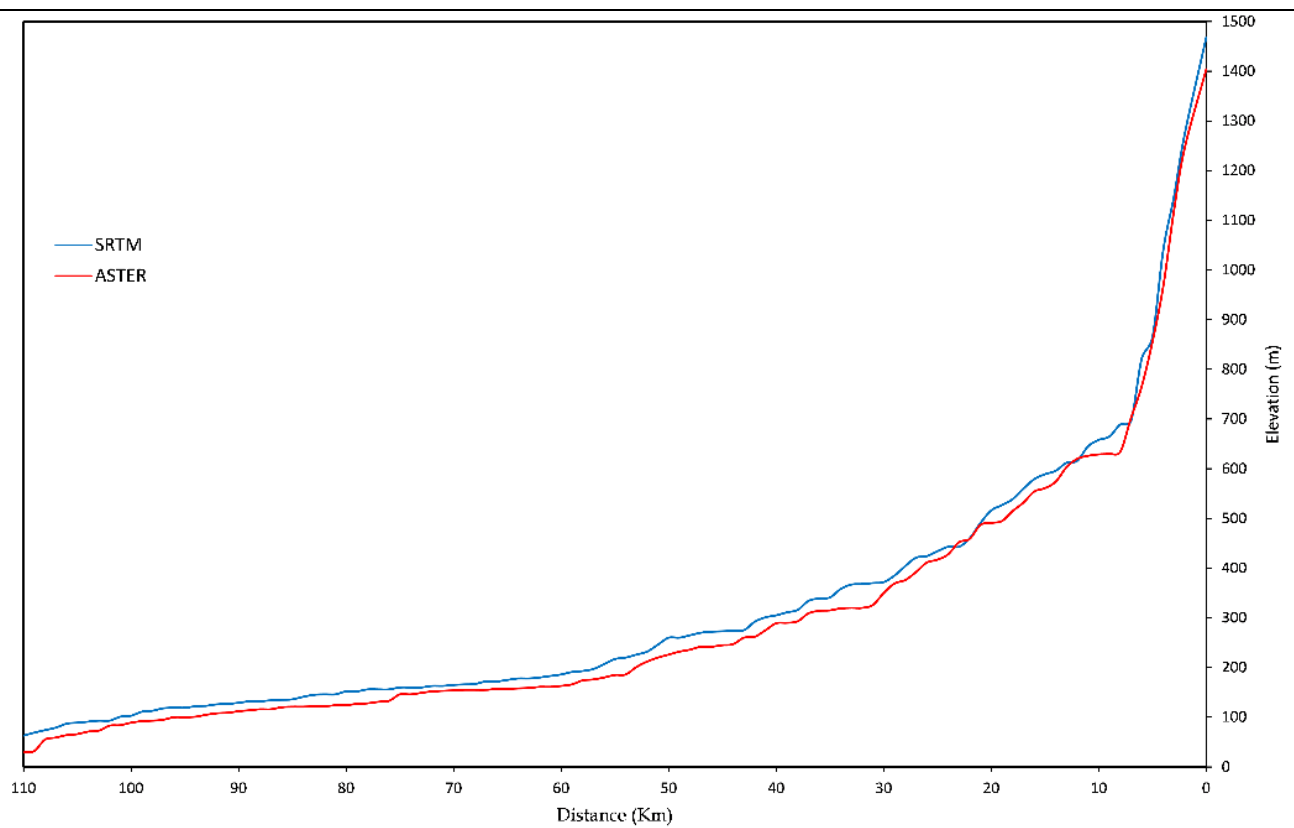

Figure 9. Longitudinal profile of Sungai Patah extracted from SRTM and ASTER DEMs.

The profiles generated from both DEMs showed a very similar pattern with only slight variation in the elevation values. The SRTM DEM gives a higher curve, by approximately $30 \mathrm{~m}$. Both profiles indicated evidence of disturbances in the base level of the river. These are evident from the longitudinal profile, where they are marked with knick points and breaks of slope, indicating modification of the terrain in response to tectonic disturbances and/or lithological changes. Both DEMs are equally suited for this type of analysis.

\section{Conclusion}

The present study demonstrated the usability and potentiality of available moderate resolution digital elevation data sets (SRTM and ASTER) for basic terrain analysis in the interior regions of Sarawak, Northern Borneo. The data sets can be used in the geoenvironmental applications like soil erosion modelling, tectonic indices derivation and landslide prediction. The assessment of basic error factors and statistics indicates good agreement with the toposheetderived elevation values, but with differences in spatial distribution. While generating stream networks for the geomorphometric analysis, stream networks derived from SRTM gave a coarser stream network than the ASTER-derived streams. The lower ground resolution of SRTM leads to underestimation of the number of stream segments, stream lengths and the subwatershed order, while the ASTER data give slightly overestimated results. Both data sets are found to be very useful in generating secondary derivatives like slope, slope aspect, relative relief and the quantitative information needed for geomorphometric analysis. They can also provide valuable information for studying the evolutional history of the basin, through the hypsometric analysis and longitudinal profile extraction, for which both data sets provided consistent results. In general, it is suggested that, besides using the SRTM and ASTER DEMs independently for terrain analysis, they can be used concurrently to overcome the limitations in both data sets and can substitute for the use of toposheetcontour-derived elevation surfaces in areas which exhibit similar terrain conditions.

\section{Acknowledgements}

The authors wish to thank Sarawak Energy Berhad for funding this research under the Project 'Mapping of Soil Erosion Risk'. They also thank Curtin University Sarawak for facilities and other assistance. The authors are thankful to the anonymous reviewer for constructive comments and suggestions, which have improved the manuscript significantly.

\section{References}

Abrams, M., Hook, S., \& Ramachandran, B. (2002). ASTER user handbook version 2. Accessed from https://asterweb.jpl.nasa.gov on 15.12.2014.

Aiken, S. J. \& Brierley, G. J. (2013). Analysis of longitudinal profiles along the eastern margin of the Qinghai-Tibetan plateau. Journal of Mountain Science, 10(4), 643-657. http://dx.doi.org/10.1007/s11629-013-2814-2

Ambili, V. \& Narayana, A. C. (2014). Tectonic effects on the longitudinal profiles of the Chaliyar River and its tributaries, southwest India. Geomorphology, 217, 37 47. http://dx.doi.org/10.1016/j.geomorph.2014.04.013

Anbalagan, R. (1992). Landslide hazard evaluation and zonation mapping in mountainous terrain. Engineering Geology, 32, 269-277. http://dx.doi.org/10.1016/0013-7952(92)90053-2

ASTER GDEM Validation Team. (2009). ASTER Global DEM Validation Summary Report. accessed from https://lpdaac.usgs.gov/ on 15.12.2014.

CGIAR-CSI. (2009). SRTM 90m Digital Elevation Data. http://srtm.csi. cgiar.org/ (accessed 19 November 2014). 
Cook, A. J., Murray, T., Luckman, A., Vaughan, D. G., \& Barrand, N. E. (2012). A new 100-m Digital Elevation Model of the Antarctic Peninsula derived from ASTER Global DEM: methods and accuracy assessment. Earth System Science Data, 4, 129-142. http://dx.doi.org/10.5194/essd-4-129-2012

Czubski, K., Kozak, J., \& Kolecka, N. (2013). Accuracy of SRTM-X band and ASTER elevation data and its influence on topographical and hydrological modelling: case study of the Pieniny Mts. In Poland. International Journal of Geoinformatics, 9(2), 7-14.

Farr, T. G., Rosen, P. A., Caro, E., Crippen, R., Duren, R., Hensley, S., Kobrick, M., Paller, M., Rodriguez, E., \& Roth, L. (2007). The shuttle radar topography mission. Reviews of Geophysics, 45:RG2004. http://dx.doi.org/10.1029/2005RG000183

Farr, T. G., \& Kobrick, M. (2000). Shuttle Radar Topography Mission produces a wealth of data. American Geophysics Union EOS, 81, 583-585. http://dx.doi.org/10.1029/EO081i048p00583

Ferraris, F., Firpo, M., \& Pazzaglia, F. J. (2012). DEM analyses and morphotectonic interpretation: The PlioQuaternary evolution of the eastern Ligurian Alps, Italy. Geomorphology, 149-150, 27-40. http://dx.doi.org/10.1016/j.geomorph.2012.01.009

Giaconia, F., Booth-Rea, G., Martínez-Martínez, J. M., Azaón, J. M., Pérez-Pe-a, J. V., Pérez-Romero, J., \& Villegas, I. (2012). Geomorphic evidence of active tectonics in the Sierra Alhamilla (eastern Betics, SE Spain). Geomorphology, 145-146, 90-106. http://dx.doi.org/10.1016/j.geomorph.2011.12.043

GLCF. (2004). ASTER Technical Guide. Accessed from http://glcf.umd.edu/library/guide/techguide_aster.pdf on 15.12.2014.

Hadley, R. F., \& Schumm, S. A. (1961). Sediment sources and drainage basin characteristics in upper Cheyenne River basin. USGS water supply paper, 1531-B.

Hengl, T., Heuvelink, G. B. M., \& Van Loon, E. E. (2010). On the uncertainty of stream networks derived from elevation data: The error propagation approach. Hydrology and Earth System Sciences, 7, 767-799. http://dx.doi.org/10.5194/hessd-7-767-2010

Heras, M. M., Saco, P. M., \& Willgoose, G. R. (2012). A Comparison of SRTM V4 and ASTER GDEM for Hydrological Applications in Low Relief Terrain. Photogrammetric Engineering \& Remote Sensing, 78(7), 757-766. http://dx.doi.org/10.14358/PERS.78.7.757

Hilton, R. W., Featherstone, P., Berry, C., Johnson., \& Kirby, J. (2003). Comparison of digital elevation models over Australia and external validation using ERS-1 satellite radar altimetry. Australian Journal of Earth Sciences, 50, 157-168. http://dx.doi.org/10.1046/j.1440-0952.2003.00982.x

Horton, R. E. (1932). Drainage basin characteristics. Transactions of American Geophysical Union, 13, 350361. http://dx.doi.org/10.1029/TR013i001p00350

Horton, R. E. (1945). Erosional development of streams and their drainage basins: hydrophysical approach to quantitative morphology. Bulletin Geological Society of America, 56, 275-370.

http://dx.doi.org/10.1130/00167606(1945)56[275:EDOSAT]2.0.CO;2

Hosseinzadeh, S. R. (2011). Drainage network analysis, comparison of digital elevation model (DEM) from ASTER with high resolution satellite image and aerial photographs. International Journal of Environmental Science and Developments, 2, 194-198. http://dx.doi.org/10.7763/IJESD.2011.V2.123
Hurtrez, J. E., Sol, C., \& Lucazeau, F. (1999). Effect of drainage area on hypsometry from analysis of small scale drainage basins in the Siwalik Hills (Central Nepal). Earth Surface Processes and Landforms, 24(9), 799-808. http://dx.doi.org/10.1002/(SICI)10969837(199908)24:9<799::AID-ESP12>3.0.CO;2-4

Jozsa, E., Fabian, S. A., \& Kovacs, M. (2014). An evaluation of EU-DEM in comparison with ASTER GDEM, SRTM and contour-based DEMs over the Eastern Mecsek Mountains. Hungarian Geographical Bulletin, 63 (4), 401-423. http://dx.doi.org/10.15201/hungeobull.63.4.3

Kamp, U., Tobias, B., \& Jeffrey, O. (2005). Geomorphometry of Cerro Sillajhuay (Andes, Chile/Bolivia): comparison of digital elevation models (DEMs) from ASTER remote sensing data and contour maps. Geocarto International, 20(1), 23-33. http://dx.doi.org/10.1080/10106040508542333

Kervyn, M., Ernst, C. G. J., Goosens, R., \& Jacobs, P. (2008). Mapping volcano topography with remote sensing: ASTER vs. SRTM. International Journal of Remote Sensing, 29, 6515-6538. http://dx.doi.org/10.1080/01431160802167949

Kusre, B. C. (2013). Hypsometric Analysis and Watershed Management of Diyung Watershed in North Eastern India. Journal Geological Society of India, 82, 262-270. http://dx.doi.org/10.1007/s12594-013-0148-x

Mahmood, S. A., Yameen, M., Sheikh, R. A., Rafique, H. M., \& Almas, A. S. (2012). DEM and GIS based hypsometric analysis to investigate neotectonic influence on Hazara Kashmir Syntaxis. Pakistan Journal of Science, 64(3), 209-213.

Seleem, T. A. (2013). Analysis and Tectonic Implication of DEM-Derived Structural Lineaments, Sinai Peninsula, Egypt. International Journal of Geosciences, 4, 183201. http://dx.doi.org/10.4236/ijg.2013.41016

Miller, V. C. (1953). A quantitative geomorphic study of drainage basin characteristics in the Clinch mountain area, Virginia and Tennessee. Technical report 3. Office of Naval Research, Department of Geology, Columbia University, New York, NY.

Patton, P. C. \& Baker, V. R. (1976). Morphometry and floods in small drainage basins subject to diverse hydrogeomorphic controls. Water Resources Research, 12(5), 941-952. http://dx.doi.org/10.1029/WR012i005p00941

Pike, R. J. \& Wilson, S. E. (1971). Elevation-relief ratio, hypsometric integral and geomorphic area-altitude analysis. Geological Society of America Bulletin, 82(4), 079-1084. http://dx.doi.org/10.1130/00167606(1971)82[1079:ERHIAG]2.0.CO;2

Pike, R. J. (2000). Geomorphometry-diversity in quantitative surface analysis. Progress in Physical Geography, 24(1), 1-20.

Prasannakumar, V., Shiny, R., Geetha, N., \& Vijith, H. (2011). Applicability of SRTM data for landform characterisation and geomorphometry: a comparison with contour-derived parameters. International Journal of Digital Earth, 4(5), 387-401 http://dx.doi.org/10.1080/17538947.2010.514010

Rabus, B., Eineder, M., Roth, A., \& Bamler, R. (2003). The shuttle radar topography mission - a new class of digital elevation models acquired by spaceborne radar. Journal of Photogrammetry and Remote Sensing, 57, 241-262 http://dx.doi.org/10.1016/s0924-2716(02)00124-7

Rajakumar, P., Sanjeevi, S., Jayaseelan, S., Isakkipandian, G., Edwin, M., Balaji, P., \& Ehanthalingam, G. (2007). 
Landslide Susceptibility Mapping in a Hilly Terrain Using Remote Sensing and GIS. Journal of Indian Society of Remote Sensing, 35(1), 31-42.

Rodriguez, E., Morris, C. S., Blez, J. E., Chapin, E. C., Martin, J. M., Daffer, W., \& Hensley, S. (2005). An assessment of the SRTM topographic products, Technical Report JPL D-31639, Jet Propulsion Laboratory, Pasadena, California, pp.143.

Schumm, S. A. (1956). Evolution of drainage systems and slopes in badlands at Perth Amboy, New Jersey. Bulletin of Geological Society of America, 67, 597-646 http://dx.doi.org/10.1130/00167606(1956)67[597:EODSAS]2.0.CO;2

Singh, T. (2008). Hypsometric analysis of watersheds developed on actively deforming Mohand anticlinal ridge, NW Himalaya. Geocarto International. 23(6), 417-427. http://dx.doi.org/10.1080/10106040801965821

Śleszyński, P. A. (2012). Geomorphometric analysis of Poland based on the SRTM-3 data. Geographia Polonica. 85(4), 45-59. http://dx.doi.org/10.7163/GPol.2012.4.24

Smith, B. \& Sandwell, D. (2003). Accuracy and resolution of shuttle radar topography mission data. Geophysics Research Letters. 30(9), 1467. http://dx.doi.org/10.1029/2002GL016643

Strahler, A. N. (1952). Hypsometric (area altitude) analysis of erosional topography. Bulletin of Geological Society of America. 63, 1117-1142 http://dx.doi.org/10.1130/00167606(1952)63[1117:HAAOET]2.0.CO;2

Strahler, A. N. (1957). Quantitative analysis of watershed geomorphology. Transactions American Geophysical Union. 38, 913-920 http://dx.doi.org/10.1029/TR038i006p00913

Strahler, A. N. (1964). Quantitative geomorphology of drainage basins and channel networks. In: Chow VT (ed) Handbook of applied hydrology. McGraw Hill, New York, Section 4-11

Tachikawa, T., Kaku, M., Iwasaki, A., Gesch, D., Oimoen, M., Zhang, Z., Danielson, J., Krieger, T., Curtis, B., Haase, J., Abrams, M., Crippen, R., \& Carabaja, C. (2011). ASTER Global Digital Elevation Model Version 2 - Summary of Validation Results August 31. Accessed from www.jspacesystems.or.jp on 15.12.2014.

Thomas, J. \& Prasannakumar, V. (2014). Comparison of basin morphometry derived from topographic maps, ASTER and SRTM DEMs: an example from Kerala, India. Geocarto International. http://dx.doi.org/10.1080/10106049.2014.955063

Tucker, G. E., Catani, F., Rinaldo, A., \& Bras, R. L. (2001). Statistical analysis of drainage density from digital terrain data. Geomorphology, 36, 87-202. http://dx.doi.org/10.1016/S0169-555X(00)00056-8

Vijith, H., \& Madhu, G. (2007). Application of GIS and frequency ratio model in mapping the potential surface failure sites in the Poonjar subwatershed of Meenachil river in Western Ghats of Kerala. Journal Indian Society of Remote Sensing, 33(3), 275-285. http://dx.doi.org/10.1007/BF03013495

Vijith, H., Krishnakumar, K. N., Pradeep, G. S., Ninu Krishnan, M. V., \& Madhu, G. (2013). Shallow landslide initiation susceptibility mapping by GIS-based weights-of-evidence analysis of multi-class spatial datasets: a case study from the natural sloping terrain of Western Ghats, India. Georisk: Assessment and Management of Risk for Engineered Systems and Geohazards. http://dx.doi.org/10.1080/17499518.2013.843437
Werner, M. (2001). Shuttle Radar Topography Mission (SRTM), Mission overview. Journal of Telecommunications. (Frequenz), 55, 75-79. http://dx.doi.org/10.1515/freq.2001.55.3-4.75

Zomer, R., Ustin, S., \& Ives, J. (2002). Using satellite remote sensing for DEM extraction in complex mountainous terrain: landscape analysis of the Makalu Barun National Park of Eastern Nepal. International Journal of Remote Sensing, 23(1), 125-143. http://dx.doi.org/10.1080/01431160010006449 


\section{SRTM ir ASTER skaitmeninės aukščio informacijos palyginimas ir tinkamumas vietovès analizei bei geomorfometriniai parametrai: Sungai Patah subbaseino (Baram upè, Sarawak, Malaizija) atvejo studija}

\section{H Vijith, LW Seling ir D Dodge-Wan}

Taikomosios geologijos katedra, Inžinerijos ir mokslo fakultetas, Curtin universitetas, Miri, Sarawak, Malaizija

(gauta 2015 m. birželio mèn.; priimta spaudai 2015 m. liepos mèn.)

Šiame tyrime buvo nustatytas iš palydovo gautų aukščio informacijos rinkinių vietovei charakterizuoti tinkamumas tropiniame Sungai Patah subbaseino regione, Sarawak viduje, Rytų Malaizijoje. Šio tyrimo tikslas buvo palengvinti greitą topografinių kintamųjų ir erdvinių parametrų, susijusių su morfometriniais regiono aspektais, įvertinimą. Buvo palyginti viešai prieinami SRTM $(90 \mathrm{~m})$ ir ASTER $(30 \mathrm{~m})$ aukščio informacijos rinkiniai ir jie panaudoti kuriant erdvinius ir neerdvinius parametrus. Kompleksinis SRTM ir ASTER aukščio paviršių, gautų iš topografiniuose lapuose atsitiktinai parinktų 200 taškų, patikrinimas parodè, kad vidutinès kvadratinès šaknies (RMSE) paklaidos buvo atitinkamai $\pm 35.08 \mathrm{~m}$ ir $\pm 44 \mathrm{~m}$. Gauti erdviniai ir neerdviniai parametrai rodo tam tikras dideles ir mažas variacijas, kurios gali būti susijusios su informacijos prièmimo sistemų erdvinių ir spektrinių rezoliucijų skirtumais. Šio tyrimo rezultatai parodè, kad SRTM ir ASTER aukščio informacijos rinkiniai gali būti naudojami ì tyrimo regioną panašiai aplinkai charakterizuoti, pakeičiant iš tradicinių topografinių lapų gautus aukščio paviršius. Vis dẻlto kai rinkiniai naudojami atskirai, atsiranda nedidelès klaidos. To gali būti išvengta naudojant SRTM ir ASTER aukščio informacijos rinkinius kartu, kas sumažintų informacijos klaidas ir trikdžius abiejuose informacijos rinkiniuose bei pagerintų aplinkos kintamųjų tikslumą ir iš jų gautus baseino parametrus.

Raktiniai žodžiai: SRTM, ASTER, DEM, geomorfometrija, hipsometrija. 


\title{
Hybrid Solar-Wind Installation Prospects for Hot Water and Heating Supply of Private Homes on the Apsheron Peninsula of the Republic of Azerbaijan
}

\author{
Arzu Huseynov ${ }^{1}$, EInur Abbasov ${ }^{1}$, Oktay Salamov $^{2}$, and Firuze Salmanova ${ }^{2}$ \\ IInstitute of Environmental Engineering, Kaunas University of Technology, Kaunas, Lithuania \\ ${ }^{2}$ Institute of Radiation Problems of Azerbaijan National Academy of Sciences, Baku, Azerbaijan \\ Corresponding author: \\ Abbasov, E., Institute of Environmental Engineering, Kaunas University of Technology, K. Donelaičio St. 20, \\ Kaunas, Lithuania \\ E-mail: abbasov.lnr@gmail.com
}

(received in May 2015; accepted in July 2015)

\begin{abstract}
This paper analyses the environmental problems arising from the use of traditional energy resources for the production of electricity and heat. The advantages of replacing conventional energy resources and shifting to wind and solar energy technologies are explained. The possibilities of the combined use of solar and wind energy to provide an average family of 5 people with hot water and heating are explored. Experimental results were obtained from full-scale tests under prevailing conditions at Baku. Solar-wind hybrid systems for heating and hot water were designed and developed at the Institute of Radiation Problems of the Azerbaijan National Academy of Sciences. The paper also examines the possibility of supplying a family of 5 people with hot water produced by solar energy year-round and presents the results of the calculation of the energy balance of such facility.
\end{abstract} tank.

Keywords: flat-plate solar collectors, wind turbine, hybrid solar-wind installation, cold water

\section{Introduction}

In recent years, environmental conditions have become much worse as a result of technogenic and anthropogenic processes taking place in the world. Literature sources indicate that since the 1980s flatplate solar collectors (FSC) have been used to supply heating (HS) and hot water (HWS) (Kharchenko, 1991; Bekman et al., 1982; Salamov et al., 2006; Carbonell et al., 2014; NREL, 2012; Sun \& Wind Energy, 2014). However, the dependence of solar radiation intensity on arbitrary changes over time, in particular the stochastic nature of this change, causes interruptions in heat and hot water supplies in differing weather conditions. One way to resolve this situation is to use very large surface area flat-plate solar collectors. Another option is to install additional equipment for the accumulation of solar radiation. Neither strategy is economically ideal. Thus, a continuous and reliable way of providing energy to consumers through the use of large surface flat-plated solar collectors in winter is not productive in spring and summers seasons, because only $10-15 \%$ of the thermal energy produced is used in place while the rest, which could be converted into other energy forms, is lost in an inefficient manner. In this case, FSCs are operating at a very critical temperature, which is harmful for inner pipes of collectors and can result in premature failure. On the other hand, the surface of a needed FSC being 5 to 6 times more than the normal size can increase costs in the same way (Salamov et al., 2006). Heat accumulative systems can be productive only in the daily and monthly provision of heat and hot water supplies, which cannot be applied for seasonal demand, and this again leads to an increase in the unit cost (Polyanin, 1998; Abdelmoneym, 1998). Thus, to provide consumers with a continuous hot water supply all year round and to ensure a sustainable heating season, solar thermal power plants are used in combination with alternative 
energy sources (Ushakova, 1986; Shershnev, Dudarev, 2006; Sun \& Wind Energy, 2014). To this end, private residential homes with natural gas use electrically-powered heating devices, and social order houses use diesel-fuelled power generators. However, in these cases, either directly (in private homes) or indirectly (thermal power plants), the use of existing resources from traditional fuel cannot be considered effective from an economic and environmental point of view. The use of wind power as a heating supply has been discussed since the 1990s; however, it is considered ineffective from an economical and ecological point of view. That is why from the beginning of this century the combined use of solar and wind energy started to become more and more important. The issue of special significance solar-wind combined installations for the production of heating and hot water supplies has become an important topic for the 'Transformation of Renewable Energy Types' Laboratory of the Institute of Radiation Problems of the Azerbaijan National Academy of Sciences since the beginning of the $21^{\text {st }}$ century as well, and successful results have been obtained. The results have been published in the periodical press from time to time (Salamov et al., 2006, 2009, 2010).

Given these premises, a combined solar and wind power installation (CSWPI) experimental model was designed and created by the 'Transformation of Renewable Energy Types' Laboratory of the Institute of Radiation Problems of the Azerbaijan National Sciences Academy. This experimental model was tested under the natural climatic conditions occurring on the Apsheron Peninsula. Below is a description of the device, its working principles, the results of the calculation and the testing of the device for supplying heating and hot water to consumers. One of the main objectives of the study is to prepare long-term strategies for high demand consumers such as schools, kindergartens, hospitals, sanatoriums, public catering facilities, factories outside the city, difficult to access strategically important locations, military installations, all based on the experience gained from the usage of the CSWPI on the Apsheron Peninsula.

Azerbaijan is one of the leading countries in the world with regard to solar and wind energy reserves. It has been determined that the Apsheron Peninsula, which is located at $40^{\circ} 24^{\prime}$ latitude, and Baku City have 300 sunny days during a year, receiving nearly 3000 annual hours of sunshine. The average solar radiation energy reaching every $1 \mathrm{~m}^{2}$ of the horizontal surface is $1900 \mathrm{~W} / \mathrm{m}^{2}$ per year, the maximum rating of solar radiation intensity during each day is $950 \mathrm{~W} / \mathrm{m}^{2}$, and the average annual rating of the same index is near 200 $\mathrm{W} / \mathrm{m}^{2}$. The ratings for working hours in winter and summer seasons are 4.8-7.8 and 7.2-12.5 hours, respectively (Salamov et al., 2013).

When it comes to the wind regime, the amount of windy days during a year on the Apsheron Peninsula and Caspian coastlines is 270-280 days, the average annual wind speed is $7-8 \mathrm{~m} / \mathrm{s}$ at a height of $12 \mathrm{~m}$, but in some places it is more than $10 \mathrm{~m} / \mathrm{s}$. All these show that the Apsheron Peninsula has significant wind potential (Salamov et al., 2010; Hashimov et al., 2012)

As can be seen, the use of ecologically clean and inexhaustible solar and wind energy to provide for the hot water and heating demands of homes has an exceptional significance on the Azerbaijani area, especially in the climatic conditions present on the Apsheron Peninsula and Baku City. For this reason, combined solar and wind energy facilities could provide consumers with more sustainable and continuous thermal energy.

\section{Materials and methods}

\subsection{Schematic structure of experimental CSWPI}

It is commonly known that the energy needs of consumers for hot water and heating can currently be satisfied by flat-plate solar collectors (FSC) and pipelike collectors that utilise solar radiation and do not require monitoring systems when operated. Along with their simple structure, another advantage of FSCs is their low cost. They allow for maximal utilisation of solar energy due to their capacity to run within a wide range of solar radiation intensity (SRI) values (Kharchenko, 1991; Panjiyev, 2007). However, studies show that a family composed of 5 members may not have a guaranteed hot water supply in winter, not to mention a supply of heating energy (Salamov et al., 2006). Under the Baku City's climatic conditions, such families will need an FSC with an overall surface area of 9-12 $\mathrm{m}^{2}$ for a reliable hot water supply, while reliable heating energy will require a much larger surface area, exceeding $50 \mathrm{~m}^{2}$. First of all, this is not an economically feasible option. Besides, such a large surface area makes the natural circulation of a heat transfer agent impossible due to the fact that connecting several FSCs in a series increases the pressure within the circulation circuit. This results in force-feed circulation, which requires operation of a circulating pump. In addition, it becomes necessary to provide automatic regulation for heat transfer agent consumption in accordance with daily fluctuations in SRI values. Such additional interventions greatly complicate the installation's structural design and reduce the consumer's interest in its utilisation. Therefore, individual households should be provided with additional energy resources for a heating power supply during heating seasons in addition to a yearround hot water supply. It has been established that wind turbines may serve as such an additional source, while their use in combination with FSCs is of even greater interest (Salamov \& Salmanova 2010; Salamov et al., 2013).

Given the above-mentioned premises, a combined solar and wind power installation experimental model was designed and created by the 'Transformation of Renewable Energy Types' Laboratory of the Institute of Radiation Problems of the Azerbaijan National Sciences Academy. This experimental model was tested under natural climatic conditions on Apsheron Peninsula. The following text provides a description of the device, the principles 
behind its operation, and the results of calculations for testing the device, which would be providing heating and hot water supplies to consumers.

Figure 1 and Figure 2 show the general appearance of the CSWPI and its simplified electric circuit diagram, respectively.

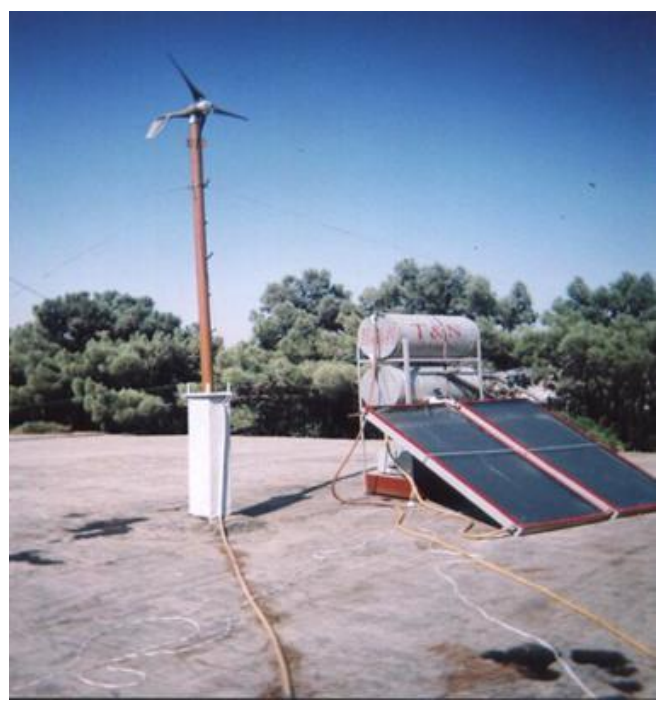

Figure 1. General appearance of the CSWPI.

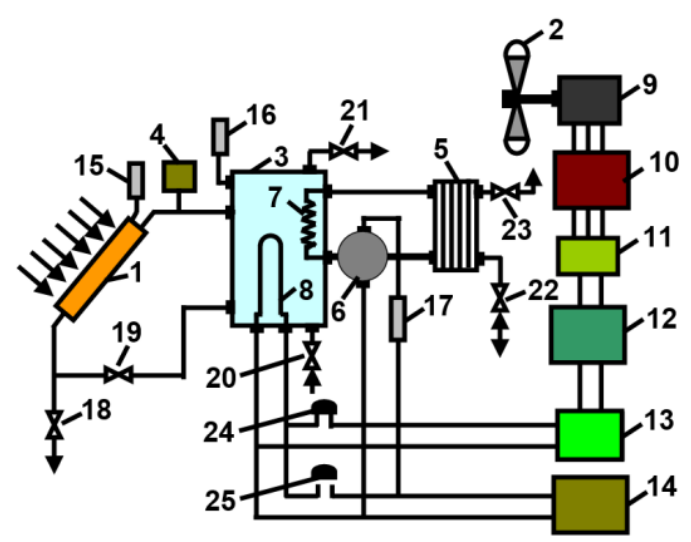

Figure 2. Simplified electric circuit diagram of the CSWPI.

The CSWPI consists of an FSC (1), a Wind Electric Machine (WEM) (2), a hot water tank (3), an expansion tank (4), a heating radiator (5), and a circulation pump (6) ensuring circulation of a heat transfer agent along the circuit. A snake heatexchanging unit (7) is installed inside the hot water tank (close to its lateral wall) and an electrical resistance heater (8) (at the centre of the tank's bottom wall). At the centre of the tank's bottom wall is located geared wind turbine (9). A voltage-reducing transformer (10) is connected to the power generator's outlet. The transformer's outlet is connected to the accumulator terminal (12) by the block for automatic control of charge and discharge processes (11). The accumulator terminal is also connected to the inlet of a phase inverter device (13). The option of using a centralised power network (14) in cases of calm weather conditions and during the hours of darkness is also foreseen. In cases where fully autonomous operation of the installation is required, a solarphotovoltaic power source may be utilised in place of a centralised power network. It should be remembered that such calm weather conditions seldom occur on the Apsheron Peninsula, especially in Baku City. For better control, the CSWPI is equipped with thermometers $(15,16)$, which receive signals from the thermocouples installed in the FSC's outlet and hot water tank (thermocouples are not shown in Figure 2). Start and shutdown of the circulating pump are directly controlled by the thermometer (17) with electrical contacts installed in the relevant place in a heated room. The installation is also equipped with regulating drain valves $18-23$. Valve 18 is considered for the discharge of a heat transfer agent in cases of long absence of inhabitants when freezing weather is anticipated, in order to prevent the bursting of FSC's pipes. As it is shown in Figure 2, Valve 19 is connected to the hot water tank according to a natural circulation scheme (in a thermo-syphon mode) and ensures the regulation of circulating heat transfer agent consumption, and by doing this, regulates the temperature regime of hot water. Valves 20 and 21 serve for filling the hot water tank and use of hot water by inhabitants, respectively. Valves 22 and 23 serve to fill the heating radiator (5) with a heat transfer agent (water also may be used as a heat transfer agent) and to eliminate any vapour locks (steam pockets). The electrical resistance heater (8) is connected to the inverter's outlet (13) and the centralised power network (14) by electrical switches 24 and 25 respectively.

\subsection{Operating principle of the experimental CSWPI}

The operating principle of the experimental CSWPI model is as follows: at the start, the surface of the FSC is turned towards the southwest and fixed at a required angle of inclination. Meanwhile, the hot water tank is placed at least $2-3 \mathrm{~m}$ above the FSC in order to enable natural circulation of a heat transfer agent. To start the operation, first, Valve 18 is closed and Valves 19-23 are opened. In this stage, the pipes of the FSC are flooded, the hot water tank is primed with cold water, and water begins to flow through Valves 21 and 23. At that moment, except for Valves 19 and 20, all other Valves $(21,22$ and 23) are closed. Sunrays passing through transparent glass surfaces of the FSC are absorbed by the heat absorbing plate, and this heats the plate. Some portion of the absorbed heat is transferred to the pipes that are directly connected to the plate. These pipes transfer this heat to the water circulating through them and the remaining heat is repelled toward the glass surface. The glass surface is not transparent to heat radiation and the repelled heat returns to the plate's surface and is absorbed by it. As a result, water flows in the FSC's pipes and the hot water tank. Later, the water that flows through Valve 19 is also heated up and provides additional heat to the hot water tank. If in winter it becomes necessary to protect the pipes of the FSC against freezing, Valves 18 and 21 should be opened simultaneously, while all other valves should be kept closed. Water is then drained from the FSC through Valve 18. Since no 
control signal from the contact thermometer is received by the circulating pump in summer, this pump remains idle and the heating radiator's circuit stays in the closed position. In winter, this circuit, receiving control signals from the contact thermometer, automatically connects to the system and the rooms in the house begin to receive heat.

\subsection{Analysis of the results obtained from the experiment}

However, studies of the CSWPI show that the FSC has played scarcely any role in heating individual households taken as study objects. This is not surprising if one remembers that on cloudy days, or during the night time hours of winter or other seasons, the FSC would not be capable of producing sufficient quantities of hot water for users without relying on additional accumulating systems. Thus, the task of providing consumers with an uninterrupted supply of hot water and heating is mainly fulfilled by a wind turbine. The use of wind turbines also offers the following advantages: the circulating pump does not need to be fed from the power network during winter, and since no home heating is required in summer, the majority of hot water needs are reserved by the FSC, and the energy accumulated in WEM may be utilised for other purposes. For example, though this study is mainly focused on the heating of individual households, it should be remembered that in summer they are badly in need of air conditioning. Upon filling the need for hot water, the remaining energy of a wind turbine may be directly supplied to fans and other electrical equipment installed in the house. The accumulator block (12) is connected to the wind turbine's outlet. Inhabitants may be fully supplied with hot water in the summer time day and night by the CSWPI on partly cloudy or cloudy days when the SRI intensity drops abruptly, or under windless conditions. Upon achieving a sufficient reserve of hot water (200-300 litres), the wind turbine may supply power to a fan in the experimental house during the hotter second half of the day and ensure an indoor temperature range of $20-22^{\circ} \mathrm{C}$ under outside temperatures of $35-40^{\circ} \mathrm{C}$.

There are a number of other advantages of wind turbine usage. During winter, there is no need to rely on the electric network to power the circulation pump. Since there is no need for heat provision during the summer season, all hot water supplies can be provided by the flat-plate solar collector. Energy produced by the wind turbine can be used for other purposes, such as refrigerators, electric lights, TVs, washing machines, vacuum cleaners, etc. In this regard, the present case discusses the heating of individual apartments, but in summer there is huge demand for the cooling of apartments, which is why the additional electricity produced by a wind turbine can be directed to electrical cooling equipment, providing sustainable cooling for residential buildings. In summer, people usually decide for themselves how to make use of electrical power produced by wind turbines.

At this time, except for electric lamps, which are not directly connected to the power grid, the remainder of household appliances are feeding phase-inverters. It is difficult for small wind turbines to directly connect to the grid-connected system; however, there is no such problem for large-scale wind turbines. If there is a sufficient hot water supply (200-300 L), WES can produce sufficient energy to cool a room to under $22^{\circ} \mathrm{C}$ when it is $35-40^{\circ} \mathrm{C}$ outside. In this case, the decline in the rooms' heating and cooling temperature is probably the same. That is why the installed equipment needs some amount of power to provide cooling in summer and heating in winter.

The FSC in the experimental CSWPI surface extends to $4 \mathrm{~m}^{2}$. The plates absorbing sunrays are equipped with a selective cover. The top surface of plates is covered with a single-layer of glass, while the bottom surface has a thermal coating, which reduces heat waste to a minimum.

\section{Information on equipment used in the experiment}

The wind turbine is a product of Yangzhou Shenzhou Wind-driven Generator Co., Ltd (SWG), a Chinese company. It is a 3-bladed, high-speed motor model SWG -E-2000, with a $3.2 \mathrm{~m}$ diameter rotor and rotor sweep area of $8.0 \mathrm{~m}^{2}$. Its specifications are as follows: nominal output power - $2000 \mathrm{~W}$; power generator type - assembled on the basis of a permanent magnet; generator $-\mathrm{Nd}-\mathrm{Fe}-\mathrm{B}$ model with 5 magnetic pole couples and a nominal output power of $48 \mathrm{~V}$; the wind's maximal operating speed $-18 \mathrm{~m} / \mathrm{s}$; the maximum permissible wind speed $-35 \mathrm{~m} / \mathrm{s}$; and the maximum rotation speed of a wind turbine's rotor spinning axis - $400 \mathrm{rpm}$. The wind turbine is connected to 4 RA12-260DG model gel accumulators. Their parameters are given in Table 1. In addition, an Xtender XTH 8000-48 model inverter with pure sinusoidal output voltage was used with following specifications: input voltage $-48 \mathrm{~V}$; optimal power $7.0 \mathrm{kWh}$; AC voltage $-220 / 180 \mathrm{~V} \pm 2 \%$; frequency $50-45 \mathrm{~Hz} \pm 0.05 \%$; and maximum efficiency $-96 \%$. The inverter stops automatically in cases of overloads and short circuits. It generates sound signals until the moment of automatic stoppage in cases of overheating. The inverter is equipped with an automation block, which regulates the accumulator charge and discharge processes.

Table 1. Constructive and energetic characteristics of gel battery type RA12-260DG combined exit of electric battery

\begin{tabular}{|c|c|c|c|c|c|c|c||}
\hline Type & $\begin{array}{c}\text { Capacity } \\
\text { A/hour }\end{array}$ & Size, $\mathbf{m m}$ & $\begin{array}{c}\text { General } \\
\text { height, } \\
\mathbf{m m}\end{array}$ & $\begin{array}{c}\text { Weight, } \\
\mathbf{k g}\end{array}$ & $\begin{array}{c}\text { Max inflow } \\
\text { movement, } \mathbf{A}\end{array}$ & $\begin{array}{c}\text { Max vacuum } \\
\text { movement, } \mathbf{A}\end{array}$ & $\begin{array}{c}\text { Internal } \\
\text { resistance, } \mathbf{\Omega}\end{array}$ \\
\hline $\begin{array}{c}\text { RA12- } \\
\text { 260DG }\end{array}$ & 260 & $520 \times 269 \times 203$ & 224 & 74.0 & 2600 & 52.0 & 8.0 \\
\hline
\end{tabular}


WEM has been installed on the property of the Radiobiology Center of the Institute of Radiation Problems of the Azerbaijan National Academy of Sciences. The small wind turbine is situated on a rooftop at a height of $12 \mathrm{~m}$ from the ground. In order to measure the wind speed, a Meteos (JDC) type anemometer was used. This anemometer also allows the measurement of air temperature. The device records 3 indicators in its light table: current wind speed on the upper line; maximum wind speed on the medium line; and average wind speed on the bottom line. In order to get precise results in the measurements, the data from the Azerbaijan Republic Department of Metrology were collected for 15-20 years at the height of $10^{-12} \mathrm{~m}$ with the same shading information. At the study site, the wind speed varies between $3-25 \mathrm{~m} / \mathrm{s}$ at that height. Figures 3 and 4 show the WEM's output power - wind speed and noise signals (when operating) - wind speed diagrams.

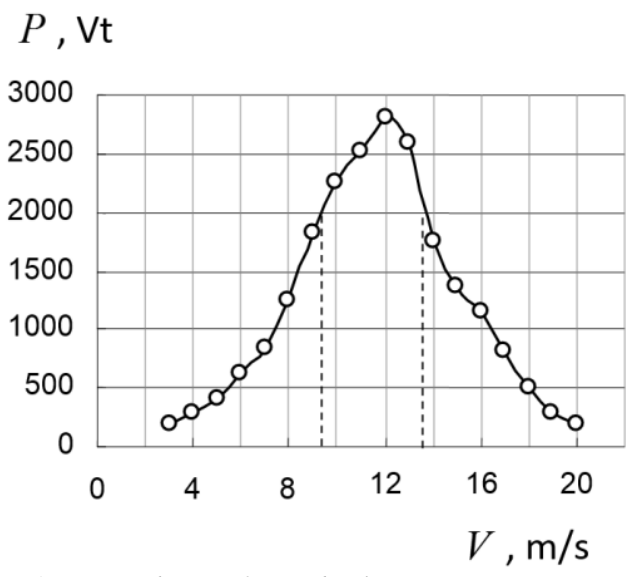

Figure 3. Graphics of wind plant power's exit power depending on wind speed.

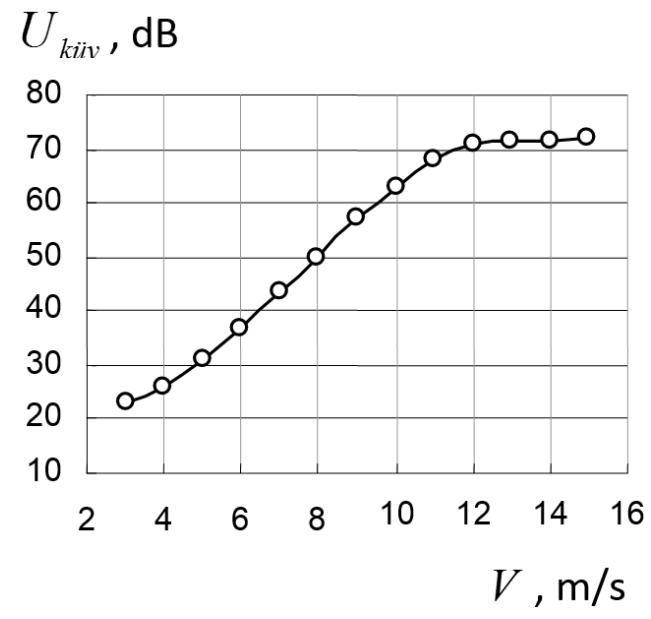

Figure 4. Graphics of noise sound level during wind power plant's operation depending on wind speed.

In order to assess the environmental impact of the wind turbine, the noise level was measured. For the purpose of measuring the sound level, an Italianproduced type HT 154, small-sized, digital apparatus was used. This apparatus was placed in special housing to absorb sound caused by wind and dimension interval changes ranging between 30-130 $\mathrm{dBA}$. The precision is $\pm 1.5 \mathrm{dBA}$, and the frequency ambit is $5-8 \mathrm{kHz}$. Dimensions were implemented every $2 \mathrm{~m}$ from a 1 to $20 \mathrm{~m}$ distance from the wind power plant ( 5 measurements were made), and then an average rating was made. As seen from the dimensions, the level of the sound signal created by the wind power plant when operating at maximum capacity is not significant for the human ear.

The selection of the accumulator battery type RA12-260DG in the apparatus is related to this battery's capacity. Secondly, it can work sustainably in the regime of both the buffer and deep inflowvacuum. Thirdly, its sustainability is longer than other accumulator battery types (about 10-15 years), and finally, they can work in a very wide temperature interval. Figure 5 shows graphics of accumulator battery capacity, which is dependent on temperature.

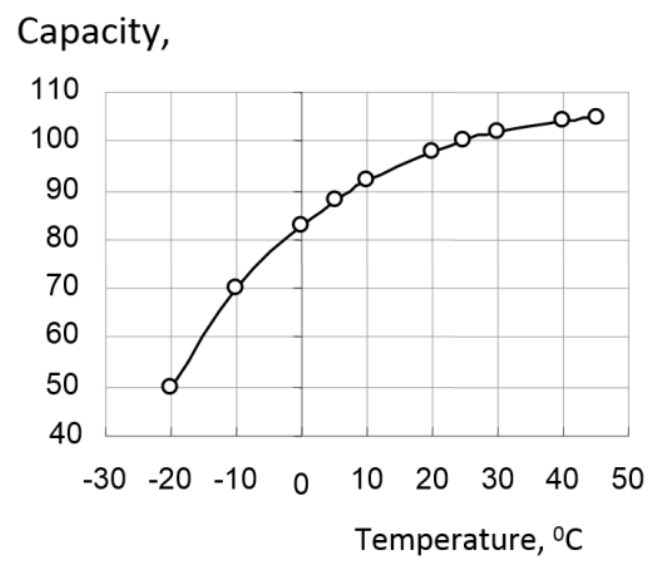

Figure 5. Graphics of gel accumulator's changing capacity type RA12 260DG depending on temperature.

\subsection{Wind regimes in meteorological stations on the Apsheron Peninsula}

There are 7 meteorological stations on the Apsheron Peninsula. In these areas, anemometers have a height of 10-12 meters and the flugers are in open areas. These stations include Apsheron Lighthouse, Pirallahi Island, stations in Baku, Zabrat, Mardakan, Mashtagha and the Sari Islands. In Figure 6 , the changing graphics of the average monthly speed of wind for Apsheron Lighthouse, Zabrat, Mashtagha and Baku stations are illustrated. When measurements were taken at these stations, real conditions were taken into consideration in much closer distances (to $2 \mathrm{~km}$ ) for the possibility of impediment that results in a shadow. The results of these measurements were corrected. Since most of the meteorological stations are surrounded by the Caspian Sea, these stations can be attributed to the higher classes for the degree of shading. But these stations are surrounded by settlements, villages, vegetation and hills, which can cause errors with changes in wind direction. These are not measurement errors but are related to statistical factors. We used references from the paper 'Prospects of Wind Energy Application in Azerbaijan' (Salamov et al., 2010). The experiments were conducted by the Hydrometeorology Investigation Bureau. We used the results from those data books. 


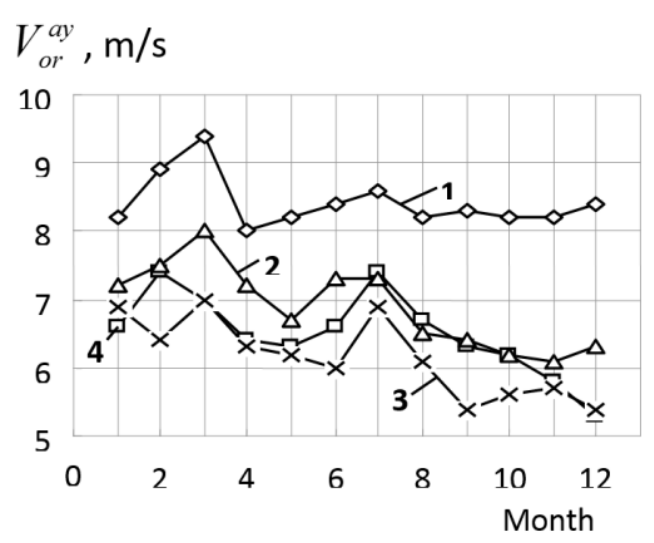

Figure 6. Graphics of changes in average monthly wind speed during a year at different locations on the Apsheron Peninsula: 1 -Apsheron Lighthouse; 2-Zabrat; 3-Mashtagha; 4-Baku.

The observations showed that the greatest annual average speed of wind at the meteorological stations on the Apsheron Peninsula was at Apsheron Lighthouse, and the least annual average speed of wind at the meteorological stations was at Sari Island (Salamov et al., 2010). But the annual average speed of wind at Sari Island is $6.2 \mathrm{~m} / \mathrm{s}$ at a height of $30 \mathrm{~m}$. This is a suitable regime for using a wind power plant that can be used in an individual form for energy production. However, considering the annual average wind speed, it would be incorrect to speak about the efficient use of a wind power plant in any district. For this, distribution characteristics should be learned during a year for the momentary wind speed for its different ranking of the annual average wind speed, as well as the amount of windless days and hours during a year. These issues were previously researched in detail for all of Azerbaijan (Salamov et al., 2010). Then, the parameters for Baku's climatic conditions were researched and the overall result was studied (Salamov et al., 2013). The results of measurements gathered at installed meteorological stations in the Mashataga settlement revealed that generally on the Apsheron Peninsula, as well as in Baku, the windless period (silence regime) of less than 12 hours captures $80 \%$ of the entire windless regime. The windless period, which continues up to 24 hours, captures $4-18 \%$ of the entire windless regime, while a 3-day windless regime reduces the capacity by only $1 \%$. However, research studies have shown that energetic silence of a more than 3-day duration period has not been observed at Mashtagha meteorological station in the last 5 years. The location where the wind's annual average speed is $8 \mathrm{~m} / \mathrm{s}$ for the number of days for different gradations of the momentary wind speed is given in Figure 7 (where $V_{a n i}-$ instantaneous wind speed).

\section{Number of days}

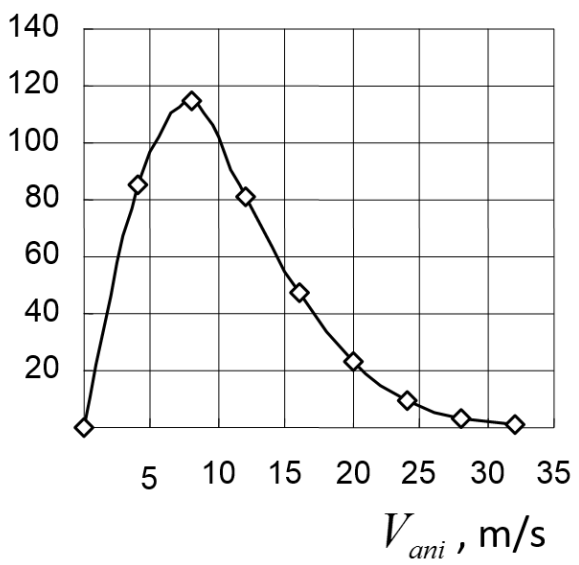

Figure 7. Frequency curve of instantaneous wind speed in the Apsheron Peninsula for the wind speed value of $8 \mathrm{~m} / \mathrm{s}$.

$V_{\text {ins }}<4-85 ; 4<V_{\text {ins }}<8$ - 114.6; $8<V_{\text {ins }}<12$ - 81; $12<V_{\text {ins }}<16-47.8 ; 16<V_{\text {ins }}<20-23.4 ; 20<V_{\text {ins }}<$ $24-9.1 ; 24<V_{i n s}<28-3 ; 28<V_{\text {ins }}<1.1$. Consequently, as it appears from the data above, on the Apsheron Peninsula, particularly with Baku City's climatic conditions, the number of days with the wind speed at which a wind turbine will be able to operate at nominal output power $\left(V_{a n i}>8 \mathrm{~m} / \mathrm{s}\right)$ is $365-80=$ 280 days. Thus, a single installation including both a wind turbine and an FSC may supply a family of 5 with uninterrupted hot water throughout the year, and with household heating for 8-9 months in a year, where hot water temperature will be $55-60^{\circ} \mathrm{C}$, while the CSWPI productivity will be 400 litres/day. In winter, maintaining the required indoor temperature by the CSWPI may present certain difficulties; therefore, in such cases, the centralised power network may need to be relied on an alternative energy source. On such days, an electrical heating element with the maximum required power of $1.5 \mathrm{~kW}$ and coated with an insulation layer may be employed as the heating element. This heating element, installed inside the hot water tank (hot water tank also playing the role of an accumulator), is connected to the wind turbine and the centralised power network by electric switches (24) and (25). Considering the minimum heat load and intended use, a single-circuit system based on natural circulation (thermo-syphon) of a heat transfer agent was used in the experimental model. At present, this choice has also been utilised with the aim of eliminating additional energy losses occurring due to the connection of the circulating pump to the circulation circuit of the hot water tank.

\subsection{Heat and hot water supply using flat solar collectors in $B$ and $C$ zones}

In addition to all of the above, we studied the possibility of providing a family of 5 living in areas with no expedient wind regime (zones B and C) (Salamov et al., 2010), using only solar energy (FSCs) even for WEMs with 10-15 $\mathrm{m}$ heights were insufficient in such zones for serving consumers' 
needs for hot water and heating. We accepted a person's daily hot water needs as being 80 litres. First, the quantity of daily average thermal load (TL) was calculated based on formulas from the reference literature. Thus, the daily heat load needs per person of a 5-member family was calculated using 80 litres water as a norm, and then this need was multiplied by the days of monthly water needed to achieve the result for heat load every month.

$$
Q_{\dot{I} Y}^{s u t}=a G_{p} \rho m N\left(t_{q . s u}-t_{s . s u}^{a y}\right)
$$

where, $a$ is hot water norm per person litres/s; $G_{p}$ - heat load of water, $\mathrm{W} /\left(\mathrm{kg}^{\circ} \mathrm{C}\right) ; \rho$ - water density, $\mathrm{kg} / \mathrm{L} ; m$ - number of family members; $N$ - days per month; $t_{q . s u} v$ ə $t_{s . s u}^{a y}-$ monthly temperature average of cold and hot water.

If we put the numbers in Equation (1) $(a=80 \mathrm{~L} / \mathrm{s}$; $G_{p}=1.16 \mathrm{~W} /\left(\mathrm{kg}^{\circ} \mathrm{C}\right) ; \rho=1 ; m=5 ; N=1 ; t_{\text {q.su }}=$ $50^{\circ} \mathrm{C} ;$ v $t_{\text {s.su }}^{a y}=15^{\circ} \mathrm{C}$ ), then we obtain the following results for heat load: $16.3 \mathrm{kWh}$ per day; $489 \mathrm{kWh}$ per 30-day month; $505.3 \mathrm{kWh}$ per 31-day month; and 460 kWh for February. Then, the heat load of cold water for Baku City was calculated (Kharchenko, 1991; Salamov and Abbasova, 2006). TL was calculated for the following parameters: temperature of water $15^{\circ} \mathrm{C}$, temperature of hot water $-50^{\circ} \mathrm{C}$, temperature of the heat transfer agent at the FSC output $t_{\text {h.tr.agent }}^{\text {outp }}=55^{\circ} \mathrm{C}$; and temperature of air - monthly average value for the zone. Temperature of water was taken as $15^{\circ} \mathrm{C}$, taking into account the annual water average in Baku City. The calculated values of daily, monthly and annual average TL are as follows: $Q^{d} T$. $=16.3 \mathrm{kWh}, Q_{T L}^{m}=496.1 \mathrm{kWh}$ and $Q^{a n} T L=5963.6$ kWh.

As it is known, using FSCs for a hot water supply requires optimal angular positioning of solar collectors' surfaces in relation to the horizon in order to ensure optimal daily, monthly and annual thermal loads. This angle is calculated as follows:

$$
\beta=\varphi+\delta
$$

where $\beta$ is the inclination angle of the FSC surface in relation to the horizon; $\varphi$ is the circle of the latitude angle (for the Apsheron Peninsula and Baku City, the value is taken as $40^{\circ} 24^{\prime}$ ); $\delta$ is the inclination angle of the vector (directed toward the sun at noon) in relation to the horizontal plane (also called 'solar declination' in reference literature), which has a positive value for the Northern hemisphere and negative value for the Southern hemisphere.

Figure 8 shows the annual variation of the solar declination angle's monthly average values. The average monthly optimal inclination angle of FSC surfaces was determined on the basis of Equation (2), which is based on the monthly average $\delta$ values provided in Table 2.

$$
\delta \text {, angle }
$$

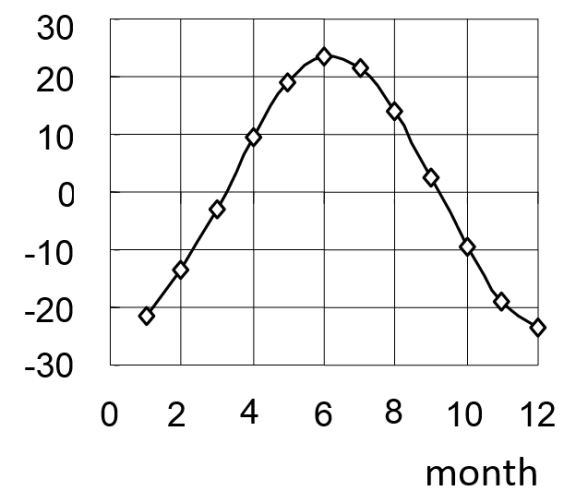

Figure 8. Annual variation of solar declination angle's monthly average values.

Testing and research work performed over a number of years have shown that even though FSCs have their own optimal inclination angle values for each day, direct connection of their structures to relevant utility lines (water, etc.) does not allow for daily angular adjustments and even the employment of automatic control systems does not prove their worth. In fact, changing the FSC surfaces' angles even during a month or only once in a season presents certain difficulties, and, therefore, they are usually fixed at some particular angular position, which may be considered the most optimal one throughout the year, while all heat- and energy-related calculations are performed for this single angle. In such cases, the solar declination angle in Equation (2) is taken to be equal to zero, which, according to Figure 8, roughly corresponds to the spring (March) and autumn (September) seasons.

Table 2. The average monthly optimal inclination angle of FSC under Baku City's climatic conditions.

\begin{tabular}{|c|c|c|c|c|c|c|c|c|c|c|c|c||}
\hline Months & I & II & III & IV & V & VI & VII & VIII & IX & X & XI & XII \\
\hline$\beta$, ang. degrees. & 61.22 & 53.78 & 42.80 & 30.79 & 21.55 & 17.35 & 19.32 & 26.75 & 38.52 & 50.23 & 59.51 & 63.45 \\
\hline
\end{tabular}

According to the reference literature, taking optimal inclination angles of FSC surfaces for the winter, spring/autumn and summer seasons ( $\beta=\varphi+15^{\circ}, \beta=\varphi$ and $\beta=\varphi-15^{\circ}$, respectively) is considered more feasible in connection with operation of FSC-based solar water heating units (SWHU). The average monthly value of SRI absorbed daily by $1 \mathrm{~m}^{2}$ of the surface is determined for these values of angles: $7^{\prime}, 8^{\prime}$, and $11^{\prime}$, respectively. In this case, the optimal inclination angles of FSC surfaces for the winter, spring/ autumn and summer seasons will be: $\beta_{W}=40^{\circ} 24^{\prime}+15^{\circ}=55^{\circ} 24^{\prime}, \quad \beta_{\text {sp-au }}=40^{\circ} 24^{\prime} \quad$ and $\beta_{\text {summ }}=40^{\circ} 24^{\prime}-15^{\circ}=25^{\circ} 24^{\prime}$, respectively. It is also important to note that when choosing between the above 3 cases for the annual average inclination angle of FSC surfaces, the latitude and longitude of the SWHUs' operation site, as well as the optimal orientation of the FSC toward the sun's trajectory (poles), should be taken into account. In order to determine the most feasible inclination angle for 
FSCs, we determined the energy and heat parameters, as well as monthly average values of its coefficient of efficiency. For this purpose, and in conformity with the study methodology, we determined average monthly values of SRI for $1 \mathrm{~m}^{2}$ of the inclined surface $\dot{I}_{\text {tot }}^{I S}$ based on analogous values for the horizontal surface $\dot{I}_{d i r}^{H S}$, specifically, 3 and 8. First, we determined monthly average values of relevant slope coefficients $\left(R_{\text {Inc. }}^{\text {mon }}=\dot{I}_{\text {tot }}^{I S} / \dot{I}_{\text {tot }}^{H S}\right)$, and then monthly average values of $\dot{I}_{\text {tot }}^{I S}$ were found. Based on the obtained results, the annual variation graphs were prepared. Figure 9 shows the annual variation of the monthly average values of daily direct $\left(\dot{I}_{\text {dir }}^{H S}\right)$, dispersed $\left(\dot{I}_{\text {disp }}^{H S}\right)$ and total $\left(\dot{I}_{\text {tot }}^{H S}\right)$ SRI for $1 \mathrm{~m}^{2}$ of the horizontal surface, while Figure 10 shows annual variation of the monthly average values of daily total $\left(\dot{I}_{t o t}^{H S}\right)$ SRI for $1 \mathrm{~m}^{2}$ of the inclined surface and $\beta_{\text {summ }}=25^{\circ} 24^{\prime}\left(\right.$ Curve 1), $\beta_{s p-a u}=40^{\circ} 24^{\prime}$ (Curve 2) and $\beta_{w}=55^{\circ} 24^{\prime}$ (Curve 1) values.

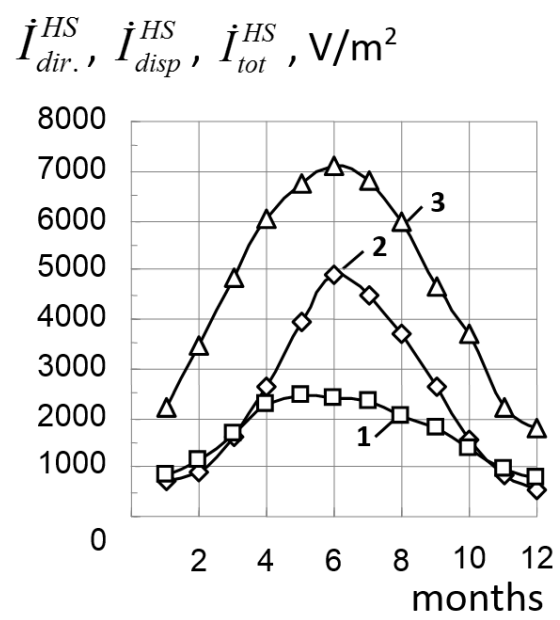

Figure 9. Annual variation of the monthly average values of daily direct $\left(\dot{I}_{\text {dir }}^{H S}\right)$, dispersed $\left(\dot{I}_{\text {disp }}^{H S}\right)$ and total ( $\left.\dot{I}_{\text {disp }}^{H S}\right)$ SRI for $1 \mathrm{~m}^{2}$ of the horizontal surface 1 $\dot{I}_{d i r}^{H S} ; 2-\dot{I}_{d i r}^{H S} ; 3-\dot{I}_{d i s p}^{H S}$.

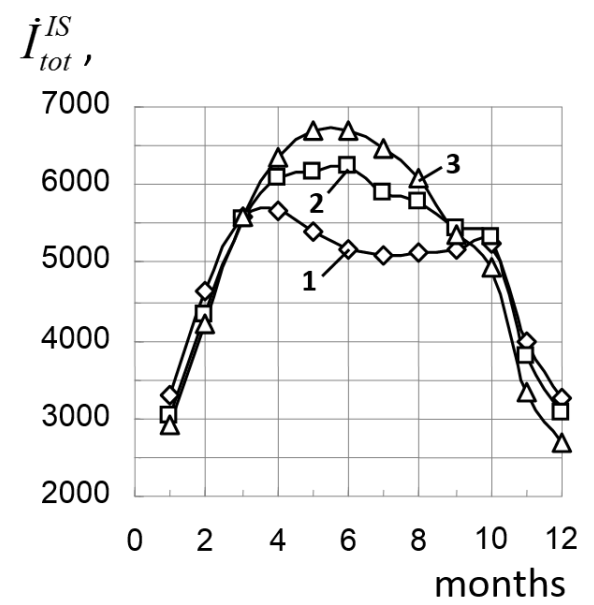

Figure 10. Annual variation of the monthly average values of daily total $\left(\dot{I}_{\text {disp }}^{H S}\right)$ SRI for $1 \mathrm{~m}^{2}$ of the inclined surface.

When comparing these 2 graphs, it becomes clear that even though the annual variation of monthly average values for $1 \mathrm{~m}^{2}$ in 3 cases showed similar behaviour (this is statistical data from Baku City),
Figure 10 shows that when FSC's optimal inclination angle is set for that of the summer optimal angle (Curve 3), the maximum value of SRI will be in summer and the minimum value in winter. Similarly, if one were to turn FSCs to the optimal inclination angle for winter, the maximum value of SRI would be in winter and the minimum value in summer. This comparison is not about SRI between winter and summer.

The comparison is the SRI monthly average between sloping surfaces and horizontal surfaces in $1 \mathrm{~m}^{2}$. On the one hand, this is a desirable option for the thermal load required in winter. It is greatly increased due to higher heat losses caused by multiple factors. In addition, the factor of utilisation of an additional energy resource diminishes.

The 3 optimal values for the FSC inclination angle, including the way the SRI for $1 \mathrm{~m}^{2}$ changes and assumes different values for winter and summer optimal angles, depend on the changing behaviour of a monthly average value of the slope coefficient $R_{\text {Inc. }}^{\text {mon }}$. Figure 11 shows annual variation of the slope coefficient $R_{\text {Inc. }}^{\text {mon }}$ for installation of an FSC at optimal angles for winter, spring/autumn and summer.

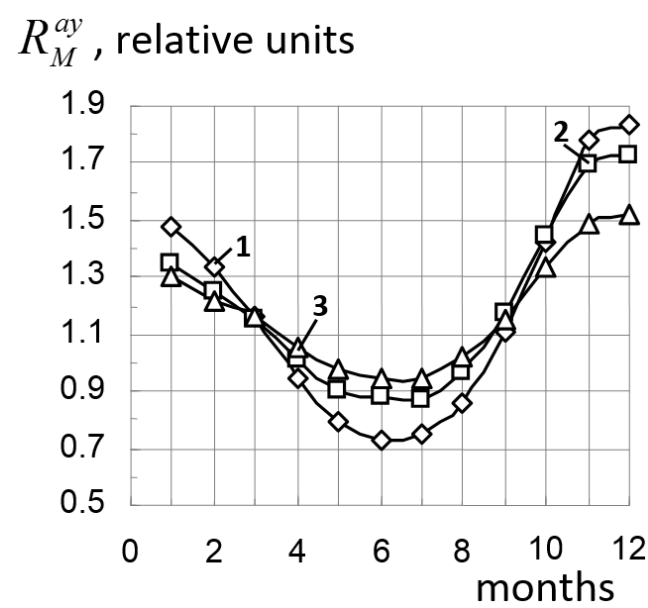

Figure 11. Annual variation of the average monthly value of the inclination angle. Curves 1, 2, and 3 represent FSC surface's inclination angles $55^{\circ} 24^{\prime}, 40^{\circ} 24^{\prime}$, and $25^{\circ} 24^{\prime}$, respectively.

The amount of solar energy falling on $1 \mathrm{~m}^{2}$ of the sloped FSC surface was calculated, such calculated values for $\beta_{w}==55^{\circ} 24^{\prime}, \beta_{s p-a u}=40^{\circ} 24^{\prime}$ and $\beta_{\text {summ }}=$ $25^{\circ} 24^{\prime}$ being $1764.5 \mathrm{~kW} /$ hour, $1846.5 \mathrm{~kW} /$ hour and $1864.9 \mathrm{~kW} /$ hour, respectively, while for the horizontal surface $\left(\beta=0^{\circ}\right)$ it amounted to $1691.6 \mathrm{kWh}$. The comparative analysis of the obtained data shows that the installation of an FSC at the angle that is optimal for the spring/ autumn period would be more feasible. Taking this into account, heat and energy calculations of SWHU in connection with compensation of daily thermal load required for supplying experimental house inhabitants with hot water during different months were made on the basis of the FSC inclination angle equal to the Baku City's circle of the latitude angle $\left(\beta_{s p-a u}=40^{\circ} 24^{\prime}\right)$.

Average monthly values of air temperature $\left(t_{\text {air }}^{\text {month }}\right)$, heat transfer agent's temperature at FSC entrance $\left(t_{\text {h.t.a. }}^{\text {ent }}\right)$ and cold water temperature $\left(t_{\text {co.w. }}^{\text {month }}\right)$ 
as well as SWHU's daily uninterrupted operation time $\left(t_{o p}^{\text {month }}\right)$ and overall surface area for ensuring the daily thermal load $S_{F S C}^{\text {month }}$ were also taken into account during calculations (annual variation of these parameters is shown in Figure 12 below).

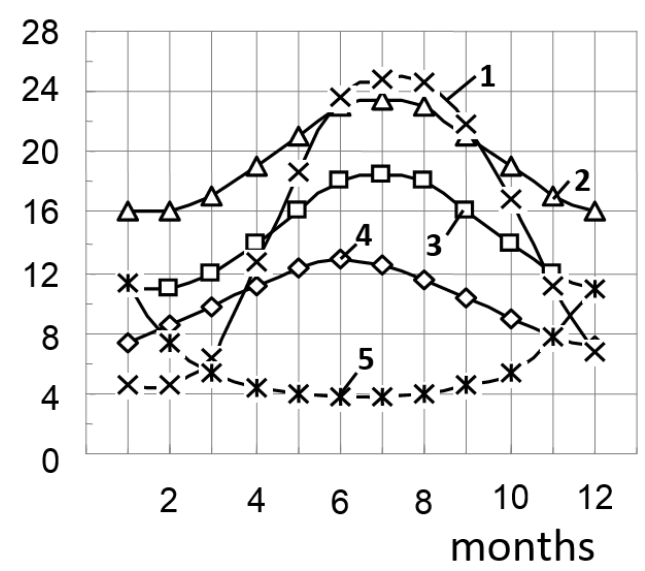

Figure 12. The average monthly values of air temperature $\left(t_{\text {air }}^{\text {month }}\right)$, heat transfer agent's temperature at FSC entrance ( $\left.t_{\text {h.t.a. }}^{\text {ent }}\right)$, cold water temperature $\left(t_{\text {co.w. }}^{\text {month }}\right), S W H U$ 's daily uninterrupted operation time ( $t_{o p}^{\text {month}}$ ) and overall surface area for ensuring the daily thermal load $S_{F S C}^{\text {month }}$ (curves 1, 2, 3, 4 and 5, respectively)

For the determination of optimal values of overall FSC surfaces, the average monthly values of daily absorbed SRI by $1 \mathrm{~m}^{2}$ of such surfaces $\dot{I}_{a b s}^{\text {day }}$ were calculated in the first instance, where the following assumptions were made: the reduced absorption capacity of FSC surface $-\theta=0.73$; reduced heat loss coefficient $-U_{h . l}=6 \mathrm{~W} / \mathrm{m}^{2}{ }^{\circ} \mathrm{C}$; and heat transfer agent's temperature at FSC outlet $-t_{\text {h.t.a. }}^{\text {ent }}=55^{\circ} \mathrm{C}$. Then, the monthly thermal load values $S_{F S C}^{\text {month }}$ required for supplying experimental house inhabitants with hot water during different months were determined along with the values of SRI absorbed by $1 \mathrm{~m}^{2}$ of the FSC surface during different months of the year $\dot{I}_{a b s}^{d a y}$ and the amount of the daily energy $Q_{e f f}^{\text {daily }}$. absorbed by an FSC and efficiently used. Figure 12 (Curve 5) shows the annual variation in optimal values of the FSC overall surface, while Figure 13 shows the annual variation of $\dot{I}_{a b s}^{\text {day }}$ and $Q_{e f f .}^{\text {daily }}$ parameters.

$$
\dot{I}_{\text {abs }}^{\text {day }} \mathrm{Vt} / \mathrm{m}^{2} ; Q_{\text {eff. }}^{\text {daily }}, \mathrm{kWh}
$$

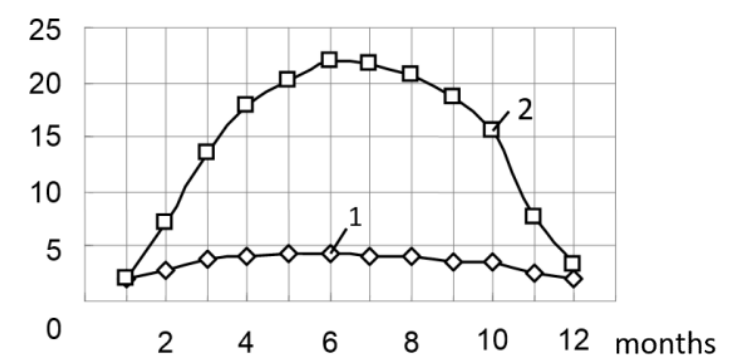

Figure 13. Annual variation graphics of daily absorbed SRI $\dot{I}_{\text {abs }}^{\text {day }}$ in $1 \mathrm{~m}^{2}$ of an FSC and effective use of solar energy $Q_{\text {eff. }}^{\text {daily }}$ by all the surface of an FSC: curves 1 and 2, respectively.
Further calculations revealed that if one were to choose FSC overall surfaces in accordance with the spring/autumn season requirements $\left(S_{F S C}^{O v} \approx 5 \mathrm{~m}^{2}\right.$ ), then, except for during winter months, users of an FSC would receive sufficient quantities of hot water, while in December, January, and February, the quantity of hot water produced daily would be 73,54 , and 52 litres, respectively. Therefore, an additional energy source should be utilised for an uninterrupted and sufficient supply of hot water. Such alternative sources may be those which run on natural gas or wind power. In cases of operation of the installation in places distant from centralised power and gas supply networks, such alternative sources may be photovoltaic power sources or WEMs. If one were to take FSC overall surfaces as equal to summer's optimal values $\left(\sim 4 \mathrm{~m}^{2}\right)$, SWHU would be capable of supplying consumers with 80 litres of hot water per person both in winter and spring/autumn months. However, this will require the use of additional energy sources, which have a negative impact on SWHU's economic feasibility. The average monthly values of the SWHU's coefficient of efficiency $\eta_{S W H U}^{\text {month }}$ as well as factors of utilisations $f_{A E S}^{\text {month }}$ of alternative energy sources and FSC $f_{F S C}^{\text {month }}$ were determined and relevant graphs were constructed on the basis of the obtained results (see Figure 14).

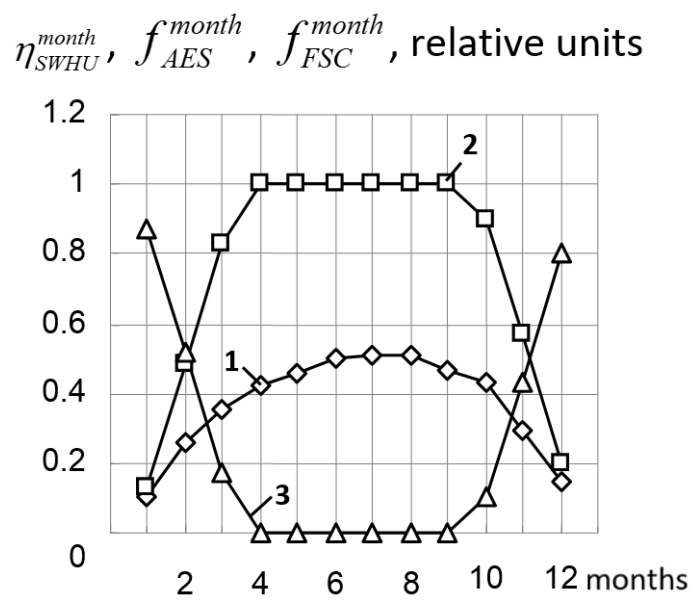

Figure 14. Annual variation of SWHU's coefficient of efficiency $\eta_{S W H U}^{\text {month }}$ as well as factors of utilisations $f_{A E S}^{\text {month }}$ of alternative energy sources and FSC $f_{F S C}^{\text {month }}$ : curves 1, 2, and 3, respectively.

Finally, monthly and yearly fuel savings for cases of alternative energy source utilisation (gas $E_{\text {gas }}^{\text {month }}$ and electricity $E_{\text {el. }}^{\text {month }}$ ) were determined. Figure 15 shows annual variation of these parameters. 


$$
E_{\text {gas }}^{\text {month }}, E_{\text {el. }}^{\text {month }}, \mathrm{kg} \text { of standard fuel }
$$

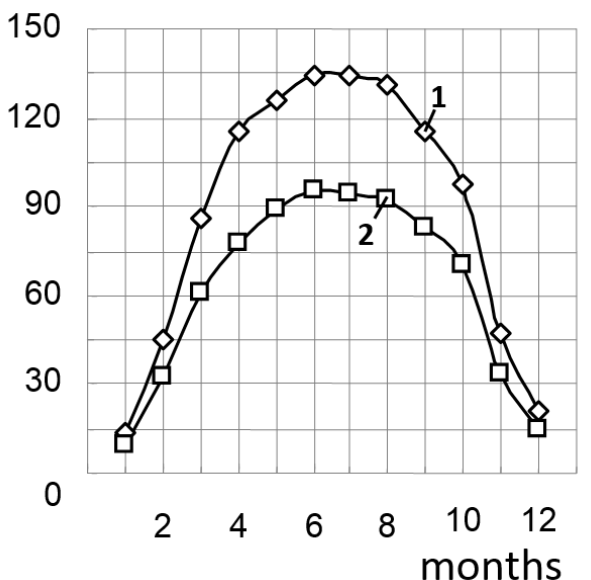

Figure 15. Annual variations of monthly and yearly amount of fuel savings for cases of alternative energy source utilisation (gas $E_{\text {gas }}^{\text {month }}$ and electricity

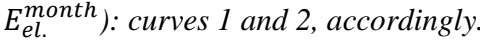

\section{Results and conclusion}

1. In this paper, damage to the atmosphere caused by conventional energy resources was reviewed. The usage perspective of low potential solar collectors was analysed. Since solar collectors cannot by themselves provide sufficient energy for heating and hot water during winter, the hybrid use of solar collectors and small wind turbines is considered to be practical.

2. It was determined that in Baku the number of sunny days equals 300 days and the number of sunshine hours are 3000 hours per year. During a year, sun radiation for a $1 \mathrm{~m}^{2}$ horizontal surface is 1900 $\mathrm{W} / \mathrm{m}^{2}$, and the maximum intensity of solar radiation is $950 \mathrm{~W} / \mathrm{m}^{2}$.The average annual value of that indicator is $200 \mathrm{~W} / \mathrm{m}^{2}$. Active solar radiation collection periods for winter and summer seasons are 4.8-7.8 and 7.2-12.5 hours, respectively. On the Apsheron Peninsula and along coastal areas of the Caspian Sea, there are $270-280$ windy days, and the average wind speed is $7-8 \mathrm{~m} / \mathrm{s}$, which in some places exceeds $10 \mathrm{~m} / \mathrm{s}$. In order to show the efficiency of wind energy, various graphs were illustrated and analysed.

3. The results of the measurements gathered at installed meteorological stations in the Mashataga settlement revealed that generally on the Apsheron Peninsula, as well as in Baku, the windless period (silence regime) of less than 12 hours captures $80 \%$ of the entire windless regime. The windless period, which continues up to 24 hours, captures $4-18 \%$ of the entire windless regime, while a 3 -day windless regime reduces the capacity by only $1 \%$. However, research studies have shown that energetic silence of a more than 3-day duration period has not been observed at Mashtagha meteorological station in the last 5 years. The location where the wind's annual average speed is $8 \mathrm{~m} / \mathrm{s}$ for the number of days for different gradations of the momentary wind speed is given: $V_{\text {ins }}<4-85$; $4<V_{\text {ins }}<8-114.6 ; 8<V_{\text {ins }}<12-81 ; 12<V_{\text {ins }}<$
$16-47.8 ; 16<V_{\text {ins }}<20-23.4 ; 20<V_{\text {ins }}<24-9.1$; $24<V_{\text {ins }}<28-3 ; 28<V_{\text {ins }}<1.1$, where $V_{\text {ins }}$ is instantaneous wind speed.

4. The subject area of research was a 5-person single family house in Baku. The possibility of providing that house with heat and hot water by using hybrid solar and wind energy was investigated. For this purpose, in the laboratory of Radiation Problems Institute, a CSWPI was established and that application was being tested for 2 years under Baku's climatic conditions. The testing revealed that the device was able to provide the family with hot water for the whole year and with heating for 8-9 months of the year (except for winter months). In order to obtain heat for the remaining months (winter months), additional energy sources were needed. For this purpose, a $1.5 \mathrm{~kW}$ maximum power consumption electric heater was sufficient. This device was powered by the electricity network. A photoelectric solar panel or a small wind turbine can also be added to make the system $100 \%$ renewable.

5. In the paper, the general view and the blocking scheme of a CSWPI were characterised and its working principles were explained in detail. Technical characteristics and the main components of an FSC and a small wind turbine were described. In particular, wind turbine exit power and noise levels are illustrated in the graphs in relation to the wind speed. The capacity changes for accumulating batteries in relation to temperature were depicted with graphs. It was determined that between the wind speeds of $9.5 \mathrm{~m} / \mathrm{s}$ and $13.5 \mathrm{~m} / \mathrm{s}$ a small wind turbine performs at its nominal power. In the conditions when the wind speed is lower than $9.5 \mathrm{~m} / \mathrm{s}$ or higher than $13.5 \mathrm{~m} / \mathrm{s}$, the power output of a wind turbine decreases. At the maximum noise level with the maximum wind conditions, the noise level does not exceed the nominal level for human health. The capacity of accumulators changes in relation to temperature. At temperatures between $0^{\circ} \mathrm{C}$ and $50^{\circ} \mathrm{C}$, the capacity increases to between $84 \%$ and $115 \%$, respectively. At temperatures lower than $-10^{\circ} \mathrm{C}$ and $-20^{\circ} \mathrm{C}$, the capacity decreases abruptly. However, these low temperatures are not observed in Baku. Thus, accumulating batteries lead to reserve energy for silent regimes without wind and still ensure that the demand for heating and hot water is met for some hours $(10-12)$. This is considered normal for the wind regime on the Apsheron Peninsula.

6. It was determined that in the summer season consumers are fully provided with hot water and there is no need for heating during that season. The energy generated from a small wind turbine remains unused for the intended purpose. Therefore, during summer, energy from a small wind turbine can be utilised for air conditioning and other domestic uses in electric appliances.

7. In the paper, the possibility of providing a 5person household with hot water and heating by using a flat solar collector was also investigated. The quantity of hot water needed per person was considered to be 80 litres daily and the monthly amount of heating for all family members was 
determined. The monthly quantity of solar radiation intensity for $1 \mathrm{~m}^{2}$ of a flat solar collector and daily quantity of SRI for the whole sloping surface were determined. This was done by measuring SRI for $1 \mathrm{~m}^{2}$ in different months and the data were obtained from data books. To this end, for transition from the horizontal surface to the slope surface, the first monthly numbers of inclined coefficients were determined. The coefficient changes during the year were depicted in the graphs of FSC's inclination angle changes during the winter, spring/autumn and summer seasons. Then, monthly numbers of effectively utilised heat energy absorbed by the surface of flat solar collectors were established. Taking into account the monthly amount of heat needed to supply hot water, the annual value of conventional fuel savings was identified. When identifying the amount of monthly savings for conventional fuel, natural gas and electricity costs as a source of additional energy, both electric heater and natural gas were taken into account. It was determined that the conventional fuel savings for gas and electric heater were $1061 \mathrm{~kg}$ and $749 \mathrm{~kg}$, respectively. It is a good indicator for application used individually. Monthly prices for conventional fuel savings are given in the form of a graph dependency. It is also used as an individual figure which illustrates a single power plant in a very good way

8. In order to assess the perspective of providing an experimental single family house with hot water and heating throughout the year, the calculation was conducted by taking into account the following: the energetic parameters of wind turbines and flat solar collectors; monthly and daily heating loads needed for heating and hot water; wind speed; environmental temperature and cold water temperature; and quantity changes for some other indicators. This is due to the fact that wind turbines and flat solar collectors are of an inherently complex nature. Experimentally, it is impossible to make a judgement about the heat-energy balance and other characteristics resulting from wind turbines and flat solar collectors. Even the data of the same month can vary significantly from year to year. That is why we took into consideration 20-year worth of data results in making our calculations.

9. The average monthly price of SWHU efficiency, FSC and an alternative source use ratio were determined. It was revealed that SWHU's maximum efficiency occurs in July and August (0.51) and the minimum cost is in January (0.1). The average annual cost of efficiency is 0.37 , the average annual value of the FSC use ratio is 0.758 , while the alternative source annual use ratio value is 0.242 . The average monthly price changes are depicted in the graphics. The results in terms of solar energy use for hot water and heating supplies show that in Azerbaijan it is significantly effective. In this sense, the energy from small wind turbines can be used effectively for the entire year. The prospects for solar and wind energy usage in Azerbaijan, as well as their use for heating and hot water supplies, were researched. In the paper, detailed information was provided about the potential of solar and wind energy on the Apsheron Peninsula.
10. According to the research, it can be concluded that in order to provide different consumers with hot water and heating supplies the usage of hybrid solar wind installations is justified both economically and environmentally. These installations are considered for individual usage and can be applied broadly to isolated areas, complex terrains, as well as for supplying hot water and heating to military installations. During summer months, heat consumption is minimal. The usage of small wind turbines enables the use of electricity for the needs of power processors (such as domestic air conditioning).

\section{References}

Abdelmoneym, A. (1988). Thermal modes of heat accumulators with a phase transition to solar heaters [Doctoral Dissertation of the candidate of technical sciences]. Moscow.

Bekman, U., Kleyn, S., \& Daffi, J. (1982) Raschet sistem solnechnogo teplosnabjenija [Calculation of Solar Heating Systems]. Moscow: Energoizdat.

Carbonell, D., Michel Y., Daniel, P., Elimar, F. (2014). Simulations of combined solar thermal and heat pump systems for domestic hot water and space heating. In Solar Heating and Cooling for Buildings and Industry (SHC 2013). Proceedings of the 2nd International Conference. Energy Procedia, 48, pp. 524-534. http://dx.doi.org/10.1016/j.egypro.2014.02.062

Hashimov, A., Salamov, O., Salmanova, F., \& Rzayev, P. (2012). Hot water and heating prospects for the use of alternative energy sources. Problems of power, 2, pp. 70-77.

Kharchenko, N. V. (1991). Individual Solar Applications. Energoatomizdat.

Mammadov, Q. \& Salamov, O. (2011). Hybrid system for hot water and heating supply Azerbaijan Republic Patent, № İ 0002 .

NREL (National Renewable Energy Laboratory). (2012). Low-Cost Solar Water Heating Research and Development Roadmap. National Renewable Energy Laboratory, NREL/TP-5500-54793.

Panjiyev, A. (2007). Prospects for the use of renewable energy sources in Turkmenistan. Alternative Energy and Ecology, 9(53), 65-69.

Polyanin, A. (1998). Guide to the exact solution of heat and mass transfer. Moscow: Energoizdat.

Salamov, O. \& Abbasova, F. (2006). Calculation of solar water heating system for hot water supply of the rural family. Alternative Energy and Ecology, 6, pp. 30-36.

Salamov, O. (2008). Automated Solar Application for heat and hot water supply. Azerbaijan Republic Patent, № I 0053.

Salamov, O. \& Garibov, A. (2009). Water heating system by solar energy. Azerbaijan Republic Patent, № İ 0085.

Salamov, O. \& Garibov, A. (2010). Solar Application for Hot Water Supply Azerbaijan Republic Patent, № İ 0031 .

Salamov, O., Mammadov, F., \& Samadova, U. (2010). Prospects of wind energy application in Azerbaijan. ISJAEE, 1(81), 132-144.

Salamov, O. \& Salmanova, F. (2010). Hot water and heating private houses from solar and wind power plants in different variants of matching them together. Alternative Energy and Ecology, 5(85), 125-126.

Salamov, O., Hashimov, A., \& Aliyev, F. (2013). Hot water and heating private houses from solar and wind power 
plants in different variants of matching them together. Alternative Energy and Ecology, 5(85), 125-126.

Salamov, O., Hashimov, A., \& Aliyev, F.(2013). Prospects for the use of solar energy in Azerbaijan. Alternative Energy and Ecology, 8, pp. 64-78.

Shershnev, V. \& Dudarev, N. (2006). The solar heating system. Construction engineering.

Sun \& Wind Energy. (2014). Booming market without subsidy, Vol. 3, pp. 34-35.

Ushakova, A. (1986). Combined solar installation to heat and cold of the experimental residential building of the Institute of Solar Energy. The test results. Ashkhabad: Turkmenniinti. 


\title{
Karšto vandens ruošimo ir šildymo nuosavuose namuose, naudojant hibridinị saulès ir vẻjo energijos ịrenginị, galimybės Apsherono ịlankoje, Azerbaidžano Respublikoje
}

\author{
Arzu Huseynov ${ }^{1}$, Elnur Abbasov ${ }^{1}$, Oktay Salamov² ir Firuze Salmanova ${ }^{2}$ \\ ${ }^{1}$ Aplinkos inžinerijos institutas, Kauno technologijos universitetas, Kaunas, Lietuva \\ ${ }^{2}$ Radiacijos problemos problemu institutas, Azerbaidžano Nacionalinė mokslu akademija, Baku, Azerbaidžanas
}

(gauta 2015 m. gegužès mèn.; priimta spaudai 2015 m. liepos mėn.)

Šiame tyrime analizuojamos aplinkos apsaugos problemos, atsirandančios naudojant tradicinius energijos išteklius elektros ir šiluminès energijai gaminti. Pateikiami ịprastinių energijos šaltinių pakeitimo ị vejjo ir saulès energiją naudojančias technologijas privalumai. Darbe buvo tyrinètos kombinuotos saulès ir vejjo energijos panaudojimo galimybès tiekti energiją vidutinei 5 asmenų šeimai. Eksperimentiniai rezultatai buvo gauti atlikus išsamius tyrimus vyraujančiomis aplinkos sąlygomis Baku. Azerbaidžano Nacionalinės mokslų akademijos Radiacijos problemų institute buvo suprojektuotos ir išvystytos saulès ir vëjo hibridinès šildymo ir karšto vandens ruošimo sistemos. Darbe taip pat buvo analizuojamos karšto vandens ruošimo galimybès 5 asmenu šeimai ištisus metus, naudojant tik saulès energiją, ir pateikti tokio įrenginio energijos balanso skaičiavimo rezultatai.

Raktiniai žodžiai: plokštieji saulès kolektoriai, vëjo jëgainè, hibridinis saulès ir vejjo ịrenginys, šalto vandens cisterna. 


\title{
Local Sustainable Energy Strategies as Opportunity for European Union Regional Development
}

\author{
Giedrius Gecevičius, Antanas Markevičius, and Mantas Marčiukaitis \\ Laboratory for Renewable Energy and Energy Efficiency, Lithuanian Energy Institute, Kaunas, Lithuania
}

Corresponding author:

G. Gecevičius, Laboratory for Renewable Energy and Energy Efficiency, Lithuanian Energy Institute, Breslaujos g. 3, LT-44403, Kaunas, Lithuania

E-mail: giedrius.gecevicius@lei.lt

(received in July 2015; accepted in November 2015)

The aim of this article is to create the methodology of energy strategies at the local, municipality level and to provide insight into the effectiveness of innovative policies and unique policy design components that can be adopted by other governments, at the local or state levels. The Regional Policy of the EU, also referred to as Cohesion Policy, is a policy with the stated aim of improving the economic well-being of regions in the EU and avoiding regional disparities. The strategy Europe 2020 stresses the so-called 20/20/20 targets.

The paper was prepared using the material, collected and analysed by implementing the Baltic Sea Region 2007-2013 programme project 'Public Energy Alternatives - Sustainable energy strategies as a chance for regional development' (PEA). The novelty of this methodology is in its holistic approach - municipality, community, business and researchers' cooperation is used. In this article, the main stages of a municipal strategy development are analysed and recommendations for regional energy strategy preparation are given.

Keywords: sustainable development, renewable energy sources, regional strategies.

\section{Introduction}

Current approaches to energy are not sustainable enough. Emphatically, energy is directly related to the most critical social aspects affecting sustainable development, such as poverty, jobs, income levels, gender disparity, population growth, agricultural production, climate change, environmental quality and economic/security targets (Peng et al., 2011). It is necessary to pay more attention to the critical importance of energy on all these aspects as the global social, economic and environmental goals of sustainability cannot be achieved without them (Štreimikienė \& Mikalauskienè, 2007). One of the key challenges is to realise these goals. Failure to take action will lead to continuing degradation of natural resources, increasing conflicts over scarce resources and widening gaps between the rich and the poor. Implementation of sustainable energy strategies is one of the most important levers in creating a sustainable world (El Bassam et al., 2013). Implementing the appropriate and complementary policy at each level of government, based on each government's competencies, allows for the creation of a synergistic policy environment that addresses multiple barriers to clean energy development. Policy implementation at the local, municipality level can provide insight into the effectiveness of innovative policies and unique policy design components that can be adopted by other governments, at the local or state levels.

Improvement and dissemination of knowledge on the methods (Calvert et al., 2013), policies and technologies for increasing the sustainability of development, taking into account its economic, environmental and social pillars, as well as the methods for assessing and measuring sustainability of development, regarding energy, transport, water and environment systems and their many combinations are the key tools for cohesive development of communities (Duić et al., 2013; Kaygusuz, 2012). 
There are still many barriers limiting current and future renewable energy production growth (Doukas, 2013). The main barriers indicated are slow diffusion of recent and current innovations, market incentives and barriers, developer incentives, cost-effectiveness and urban implementation (Walker, 2008). It is important to emphasise that the evolution of policy instruments applied to the environment, social and economic sectors has made a significant influence on sustainable development framing (Zaccai, 2012).

Although the European Union is one of the richest parts in the world, there are large internal disparities of income and opportunity between its regions. Regional policy transfers resources from richer to poorer regions. The argument for regional policy is that it is both an instrument of financial solidarity and a powerful force for economic integration. The Regional Policy of the EU, also referred to as Cohesion Policy, is a policy with the stated aim of improving the economic well-being of regions in the EU and avoiding regional disparities (Peng et al., 2011). More than one-third of the EU's budget is devoted to this policy, which aims to eliminate economic, social and territorial disparities across the EU, restructure declining industrial areas and diversify rural areas which have declining agriculture. In doing so, the EU regional policy is geared towards making regions more competitive, fostering economic growth and creating new jobs. The policy also has a role to play in wider challenges for the future, including climate change, energy supply and globalisation (Atici \& Ulucan, 2011).

Nevertheless, strategy Europe 2020 stresses the importance of energy efficiency in the EU more specifically (Baležentis et al., 2011), the so-called $20 / 20 / 20$ targets, namely a reduction of greenhouse gas emissions (by 20\%), an increase in the share of renewable energy (20\%), and an increase in energy efficiency, thus, saving up to $20 \%$ of energy consumption; the strategy also implies the need for elaborating appropriate policy measures aimed at achieving the aforementioned aims by 2020 (TolónBecerra, Lastra-Bravo, \& Botta, 2010). Article 4 of the Renewable Energy Directive (2009/28/EC) requires EU Member States to submit national renewable energy action plans and provide detailed road maps of how each Member State expects to reach its legally binding 2020 targets for the share of renewable energy in their final energy consumption.

A very important target in this area is diversification of energy sources and climate change mitigation policies (Lindseth, 2004; Sperling et al., 2011; Tolón-Becerra et al., 2010). The main issues and the background of sustainability in the energy sector are reduction of energy intensity and increasing energy efficiency.

The benefit of these strategies covers not only mitigation of the climate changes, but also improvement in the quality of living conditions in a city and the health of inhabitants. Also, it is very important to implement statements and obligations of the Covenant of Mayors, which cover the aims of sustainable energy development strategies (Sperling et al., 2011). To promote sustainable energy strategies requirements, policy measures, environmental and energy agencies' data were analysed (Lantz et al., 2007). Local policy development allows experimentation as each government creates the policy adopted to the local conditions (Lutsey \& Sperling, 2008). In contrast, the policy developed at the state or national level to be implemented by local governments may not provide effective flexibility in the local context (Rammel \& Van Den Bergh, 2003). Implementing the appropriate policy at each level, based on each stakeholder's competencies, allows for the creation of a synergistic impact of the policy that addresses multiple barriers to sustainable development. Policy implementation at the local level can provide innovative sight and unique design components that can be adopted at the local or state levels creating the policy (Lindseth, 2004). Moreover, policy development at the local level may be more effective in addressing some barriers because achievement of social acceptance on a smaller scale is easier. It is necessary to create local issue and to increase involvement of local community in the local processes because inhabitants have the ability to be involved in the decision-making process (Busche, 2010). Moreover, business stakeholders cannot make significant influence over local governments and citizens can make influence on policy development at the local level (Byrne et al. 2007). The clean energy idea grows in many communities and it makes implementation of sustainable energy policies at the local and national levels easier. It is important to mention that action at the state level is significant, but local governments should make essential impact on the framing of the sustainable energy policy (Štreimikienė \& Mikalauskienè, 2007).

The essential principle for local sustainable development (SD) is that municipalities decide themselves on the main targets on which they will focus. Local stakeholders know better where the best chances of successful implementation lie. They can develop environmental and other measures or understand how to adapt the policy to local needs. The fact that municipalities can adapt a local SD policy to their own local environment makes local SD policy specific and valuable. This removes the risk of vagueness and disparity between communities and other stakeholders. Improved social, economic and environmental situations are the points that enter the idea of the sustainable energy strategy and give shape to realistic aims within a clearly defined structure (Peterson \& Rose, 2006).

Policy implementation at the local level creates flexibility to understand local needs. Local governments' knowledge can help frame the local discussion covering clean energy, and also demonstrates benefits addressing to local issues (Busche, 2010).

Assimilation of EU structural funds for local projects creates the possibility to address regional disparities and local needs and achieve the main objectives of the European policy more effectively. Therefore, the main strengths are greater 
experimentation by a variety of policy makers, large flexibility, better correspondence to specific local needs, citizens' involvement, lower impact of lobbies and better transparency of financial instruments. Several functions of municipalities related to sustainable energy development issues are:

- preparation of programmes related to the development of housing;

- organisation of heating and water supply and wastewater collection and treatment;

- development of municipal waste management, maintenance of municipal buildings, roads and streets of local significance;

- implementation of regional development programmes.

As a result, municipalities play an important role in the energy sector and have the ability to introduce renewable energy systems and increase energy efficiency. Municipalities have opportunities in local energy plans to involve energy-efficient housing, waste collection and management systems, renovation and modernisation of the heating system and renewable energy sources projects (Del Río, 2011). The implementation of efficient street lighting is also an important source of energy savings at the local level. Municipalities have powers in preparation of long-term strategic development plans, detailed master plans and short-term strategic activity plans (Štreimikienė \& Mikalauskienè, 2007).

\section{Materials and methods}

This paper was prepared using the material, collected and analysed by implementing the Baltic Sea Region (BSR) 2007-2013 programme project 'Public Energy Alternatives - Sustainable energy strategies as a chance for regional development' PEA. In total, 21 partners from 6 countries (Estonia, Finland, Germany, Latvia, Lithuania and Poland) around the Baltic Sea together with experts from various scientific areas of expertise analysed what potential energy saving capacities existed that could be added, strengthened and expanded. The project was designed to work out energy strategies for 9 municipalities that would help countries all over the Baltic Sea region and beyond to rethink their energy production, raise awareness of alternative energies and encourage municipalities and regions to meet European energy standards as soon as possible. The strategies are prepared on the basis of existing approaches for energy strategies, regional SWOT analysis, networking with regional, national and transnational business and scientific partners and benchmarking at the European level. The targets are allocated for short-term, medium-term and long-term perspectives. Finally, the activities are added to the targets established. Baltic Energy Strategies for the regions were elaborated and compiled to a set of measures and possible results for other regions in the BSR.

The Law on Energy from Renewable Sources was adopted in Lithuania in 2011. According to this law, all municipalities were obligated to prepare strategies for usage of renewable energy sources in Lithuania. The lack of uniform methodology on preparation strategies existed in that period and still exists. A compilation of paper findings will help to make the possibilities of public energy management visible, help other communities and regions to elaborate their ideas and find their ways into the future with renewable energy and lower energy costs.

\section{Results and discussion}

\subsection{Preparation of sustainable development strategy}

In a common approach, each region worked out a strategy that was discussed and enhanced by the partnership in a transnational environment. The strategies are developed through the evaluation of existing approaches towards energy strategies, regional SWOT analysis, networking with regional, national and transnational business and scientific partners as well as benchmarking at the European level. The first step for preparation of an SD strategy is evaluation of the situation in the local environment and region. Self-assessment analysis is based on statistic indicators. The next step is to frame targets for municipalities. The targets are presented for short (5 years), medium (15 years) and long terms (25 years). The flow chart of the framework of local SD strategy development is presented in Figure 1.

The municipality should establish policy guidelines for short-term, medium term, long-term periods, and the framework should cover industry, agriculture and forestry, municipal services, households, transport, local electricity and heat production, as well as waste management. Moreover, local SD plans should cover the areas under jurisdiction of municipalities, establish actions for climate change mitigation and increase energy savings and use of renewable energy sources in these areas (e.g. local road infrastructure, implementation of efficient street lighting, increase in forest area, improvement of a waste management system and use of collected biogas from landfills for energy generation). The national targets for green gas emission (GHG) reduction, energy savings and use of renewable energy sources are presented for the year 2020 and they should be used as the guidelines for establishing targets at the local level. 


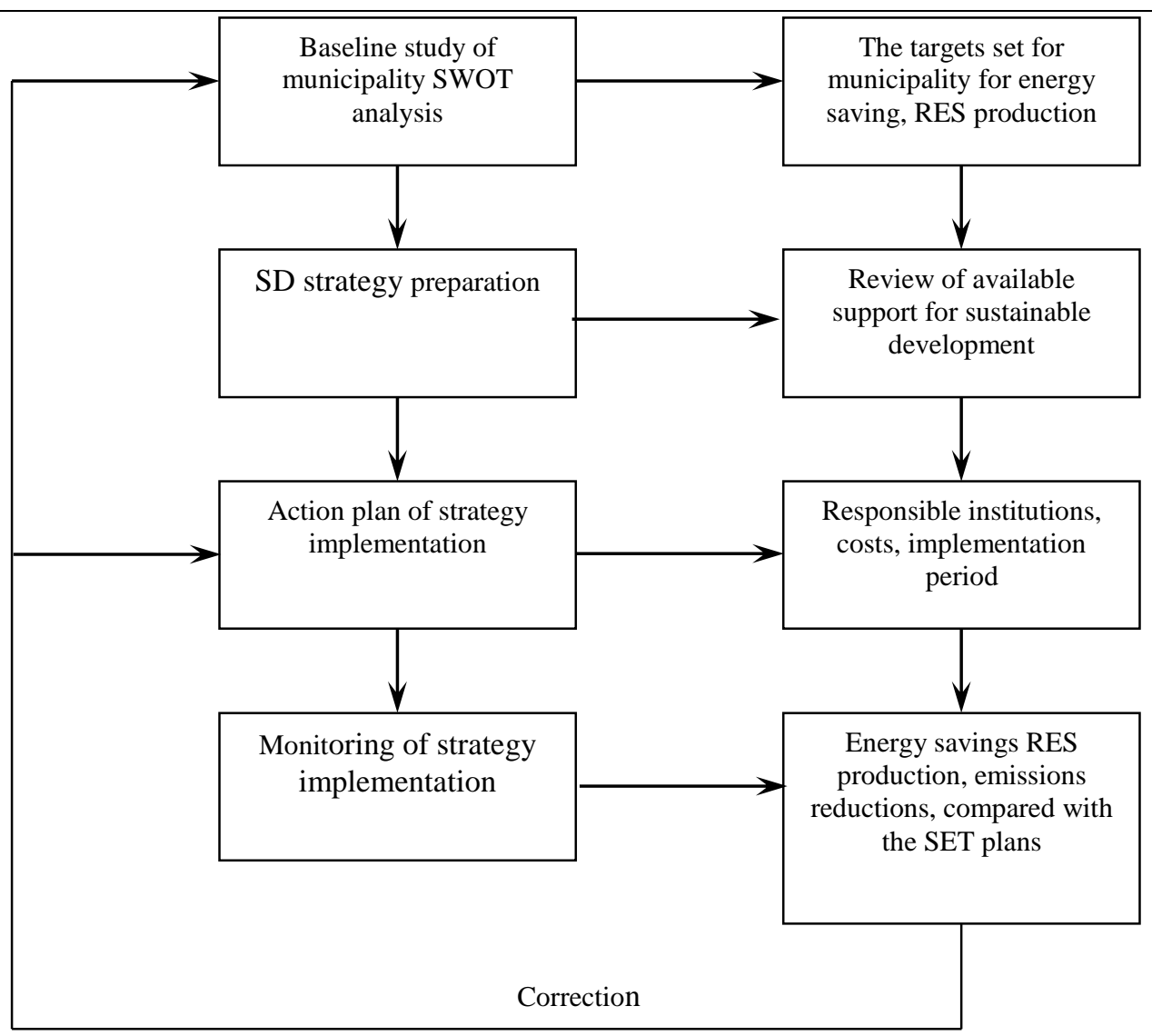

Figure 1. The framework of local sustainable development strategy.

\subsection{Management}

Within the PEA project, regional energy strategies were elaborated for the following partner regions: RCG Prignitz in Germany, Mustvee, Rauge and Varu in Estonia, Lahti and Ylivieska in Finland, Kraslava in Latvia, Ignalina in Lithuania and Niepolomice in Poland. The main aim of this work was to outline measures and possible results for other regions. The general strategy aims at reduced energy usage and higher added value based on regional resources. Energy efficiency and the use of alternative energy sources are not only technical problems but also strategic ones. It is not enough to say that energy should be saved and new forms of energy production must be considered - the question remains: what can they do to establish themselves as 'Energy Regions', to create new profiles and to get fit for competition in social, political and economic contexts? To simply regard sustainability and self-sufficiency aspects alone is not enough. An energy measure should not only be financeable but also profitable for the region and actors. In this way, the strategy will gain acceptance and support from citizens and, thus, will have increased chances for successful implementation throughout. The main problems result from the highcost level of most of the measures. Also, not all of the factors and variables can be considered, because there is a limited scope of responsible stakeholders and actors. There are fields like the demographic change or energy price fluctuations, which are very difficult to control. All these problems were tackled in a common but individualised approach, i.e. each region worked out a strategy that, in the course of work, was discussed and enhanced by the partnership in a transnational environment. The strategies were developed through the evaluation of existing approaches towards energy strategies, regional SWOT analysis, networking with regional, national and transnational business and scientific partners, benchmarking at the European level, etc. Developing strategies for sustainable energy consumption and energy production from (preferably renewable) locally available energy sources helps the regions to improve their overall development options as regional development mainly depends on the capacity of innovation and on the readiness to improve and change a given situation. The regional energy strategies of the partner regions demonstrate that there are 3 main requirements to achieve this: raising the awareness of energy problems, working on new financial and management models, and concrete implementation measures.

A regional energy strategy as a document should work on an agreed basis for further development and decision making in the energy sector. Now that the partner regions have compiled their baseline papers and regional energy strategies, a set of recommendations has been compiled as a supporting 'manual' for all those regions which would like to carry out a similar exercise in future. 


\subsection{Recommendations for regional energy strategy development}

The whole process of strategy development can be divided into 5 stages, starting with collection of information and the mapping of a status quo. This leads to a gaps analysis, then an estimate for the potential realisation and, finally, results in a detailed action plan for implementing identified preferred measures.

The following diagram illustrates these main components of the development of a regional energy strategy:

\begin{tabular}{|c|}
\hline $\begin{array}{c}\text { Definition of energy situation } \\
\text { Consumers-producers-resources (Baseline Paper) }\end{array}$ \\
\begin{tabular}{|c|}
$\boldsymbol{\downarrow}$ \\
Identifying priorities \\
Wishes and reality
\end{tabular} \\
\hline $\boldsymbol{\text { Scenario building }}$ \\
\hline Possibilities, capacity, alternatives \\
\hline \\
Action plan \\
Activities, resources, time scale \\
$\boldsymbol{\downarrow}$ \\
Implementation \\
Investment, management, evaluation
\end{tabular}

Figure 2. The main stages of strategy development.

\subsubsection{Analysis and definition of the energy situation. Preconditions}

The reliability of an energy strategy depends on the quality of preliminary work and initial data.

Before an energy balance (energy production and consumption) is drawn up, it is important to think over the preconditions. Before starting the work, the following questions must be answered:

1. Why is it necessary to do the strategy?

2. What was the situation before?

3. Is there enough competence to make the strategy?

4. Is there a team for the task ahead?

5. Is there enough knowledge to ensure that the strategy is prepared properly?

6. Where and how can the necessary demography, housing, energy, fuel, etc. related data be acquired?

7. Will it be possible to collect the necessary data, what kind of data is available?

8. Who are the stakeholders of the region, whose opinion should be considered?

9. Who can help in case of the need for assistance?

10. Are there sufficient finances secured for the development of a strategy?

\subsubsection{First activities - baseline paper}

The first important steps are a mapping exercise and data collection. Each region that is going to develop a regional energy strategy should prepare a paper on the status quo of the region first. This includes general information on the region (location, economic development, demographic development, size and geographic background) and general information on energy issues, such as power capacity, consumption and sources of energy production. It is important to analyse background data, such as reasons for varying energy consumption, the mix and size of energy consumption, etc.

Each region should collect the relevant data (preferably in the form of a SWOT analysis to identify strong and weak points of the region and its potential for future development and identification of planning potentials and threats). The resulting baseline paper is a prerequisite for developing a regional energy strategy.

For the preparation of a comprehensive energy strategy, local regional administration should be checked for the availability of:

1. development plans, decisions concerning the energy sector and earlier local regional development strategies, especially those including the energy sector analysis;

2. legal documents and statistic information;

3. economic analysis information about the land use;

4. other relevant data and documents (available renewable energy sources (RES) and rational use of energy (RUE) potentials).

General advice can be given for the elaboration of a successful energy strategy baseline:

- Professional management actions should be used for active involvement members of the team.

- Reliable data are key in making a reliable strategy. Time invested here is time saved on correction of mistakes later.

- Some examples of high-quality strategies should be studied.

- It is always good to learn from the mistakes of others to avoid yours.

Having collected all the data necessary for further planning, the outcome should be analysed, the resource potential should be estimated, graphics drawn, tendencies analysed and then the following questions should be answered:

1. Does the outcome of the analysis match the expectations?

2. Are the goals for the future realistic? A specialist should be consulted.

3 . Is the committed work beneficial?

4. Are there enough people/resources/land/forest to achieve the goals?

5. Are the goals in consistency with national priorities regarding regional development and energy sector?

6. Are there enough funds for achieving the goals? If not, what are the alternative funding sources?

7. Does the idea for the future of the region cope with the needs of the region? 


\section{strategy}

Planning and forecast for a regional energy

Before starting to develop a regional energy strategy, one more critical look should be taken at the outcome of analyses of the collected data. It is very important to understand that some essential information is still missing or some sources of information or members of the community have been neglected. The gaps should be bridged and the work continued.

An appropriate time span for planning and forecasting should be set. Time range allowing the team to cope with the task should be chosen.

Below are the pieces of advice for successful planning and forecasting:

- Planning should be realistic, originating from real data and figures.

- Overestimation and too optimistic figures should be avoided in the forecast.

- All development options should be communicated to local community, involving and listening to them.

- Conflicts with local community should be avoided. Solutions which will not be accepted or which might damage local historic cultural heritage should not be forced.

- Priorities and goals should be revised if necessary.

- A holistic approach should be used for a regional energy strategy.

- Specific situation in the target region should be considered.

\subsubsection{Setting objectives and identifying priorities}

It is very important to identify clear objectives and priorities. It will give a direction for all stakeholders. A target could be described as greenhouse gas emission reduction to become energy self-sufficient in the long-term period. The main idea of that could be described as work for a better climate to participate in reaching national objectives.

In order to reach all target groups, it is important to raise awareness and readiness to exploit new possibilities. It is also important to consider all stakeholders that take part in the energy strategy:

- government/municipality;

- private actors/consumers;

- local and regional enterprises;

- organisations and associations.

An increase in sustainability in a certain region can only be reached when the strategy includes some essential steps and issues. First, reduction of greenhouse gas emission is of concern. It is important to involve individual emissions of the local community. Also, energy usage has to be reduced and the share of renewable energy increased through the use of local resources. At the end of this process, the goals should be evaluated.
In order to set certain goals, it has to be considered whether municipalities cannot achieve objectives on their own. All stakeholders should be involved from the community, business, research area and municipality. Furthermore, objectives should be considered in combination due to the correlation of related aspects.

Criteria to identify a realistic feasibility have to be defined in order to determine the practicability of strategies, and setting criteria will enhance the transparency of the sustainable energy strategy.

The first criterion covers economy. An energy strategy should lead to budget revenue but also keep those benefits within the region and the country.

The second one is the contribution to local socio-economic environment, which is especially important in areas with declining populations and revenue. The idea is that the economic revenue provides mutual benefit for both the economy and the society.

The third criterion is oriented to sustainable development and each stakeholder should be able to evaluate an idea or measure and its effectiveness in terms of contributing to energy objectives. Energy planning might not be the equivalent of a formula, e.g. placing wind turbines within vulnerable landscape may not be sustainable in the long term.

\subsubsection{Scenarios and pilot projects}

The development of scenarios reveals the impact of a strategy. Scenarios can be worked out on the basis of technical potential, different criteria, and the impact of a strategy that focuses only on one source or a strategy using a combination of sources. A combination of those scenarios is a common practice in the development of energy strategies. Possibilities can also build up on:

- an energy saving scenario;

- a renewable energy scenario;

- a scenario based on the lowest investment costs;

- a scenario based on the lowest energy price for end users;

- the lowest spatial impact;

- the highest level of participation from stakeholders.

Scenarios will clarify the challenges and the processes that project planners will use to facilitate the process of engaging different partners to become involved in sustainable energy planning.

Pilot projects can serve as a basic line, to explore in the case of uncertainty or gain support by setting a small but convincing example for comparison. It could also be used to indicate or benchmark certain indicators. In some environments, pilot projects work as a teaser to attract awareness and create further demand. A pilot project can also be the first part of a series of steps 
and may create the required basis for starting another activity under improved conditions.

There is a difficulty and hazard regarding pilot projects and their comparability, as conditions may vary over time. If a topic becomes unattractive during the implementation of a pilot project, the implementation could suffer as a consequence. If the findings of a pilot project are not as convincing as hoped for, often mechanisms and dynamics may develop on besides the rationale of it. These 2 situations are difficult for a project to control and need to be included in the scenarios to prepare for appropriate and satisfactory reactions.

\subsubsection{Development of an action plan}

In order to ensure sustainability and durability of regional energy strategies, it is important to work out action plans for implementation. This will include elaboration of concrete work, definition and identification of actors and partners for regional implementation processes, setting the time frame and correspondences for different actions and defining the financial conditions (investments, rewards, expectations and thresholds). As for establishing an energy region certain preconditions are necessary, it is clear from the start that not all partner regions and municipalities are able to reach this status. However, efforts will be made to create regional/local profiles on energy-related topics that will help the respective partner(s) to find ways for a sustainable and futureoriented development, but also to scale individual involvement and contribution for efficiency.

A further important part of action plans should be the activation of relevant public and political actors beyond the group of upfront participants. All these actors should be involved in decision-making processes and should be enabled to contribute with their own ideas and express their resentments.

Implementation also includes multiple and significant financial aspects. In general, investments should be conducted in order to provide the basis for implementation, and they need to follow standards of procurement and transparency, wherever public money or public bodies are involved. Search for and commitment of investors should be professionalised and made available for overall economic development of the regions. In the end, agreements for coinvestments of municipalities and private investors should be explored, e.g. in the form of public private partnerships. Options and possibilities should be identified and documented and experiences shared and discussed with project partners. Know-how transfer should play an important role. Eventually, all these activities should lay the grounds for investments and pilot projects and smoothen the way for other fields of actions, too, e.g. by attracting to think in parallels and similarities of the best practice.

Raising awareness of energy topics for municipalities and regions is one of the main aims of the action plan. This is also true for implementation strategies - it will not be enough to elaborate strategies on what could be done; it is also important to show how it can be done. The key aspect is communication on various levels. It needs to be stressed that the key to successful communication and final adoption of the efforts (a kind of a success story) has to do with a sophisticated communication plan and structure. While the action plan, and especially the action, is closely followed and positive events along implementation are to be wished for, communication also has a role to reveal and alarm in the event of shortcomings and to report and document how any mischief was overcome. Therefore, while this aspect dominates, it plays a vital role to enable and secure progress and success throughout all 5 steps.

\subsubsection{Implementation}

For the implementation process to work out well, with control and continuation secured, it is important to have full-time staff allocated (preferably not e.g. a politician, who might lose his/her constituency during the lifetime of a project). The strategy itself should be reviewed and reconfirmed periodically, best once a year. The change in relevant indicators should be observed. If needed, the action plan has to be adapted. For any change to the layout, specialists and local stakeholders should be involved. Before large-scale investments are made, different opportunities and several offers have to be considered. Since the strategy concerns the development of the environment and the social community of the region, up-to-date information and professionals on the required field must be utilised.

If full investment cannot be made right away, a step-by-step approach should be used. Everything done should have considerable outcomes and impact. Advice can be the following:

- to secure communication between stakeholders;

- investments are easier to be proven if one can refer to 'best practices'.

\section{Conclusions and recommendations}

A specific energy strategy is transferrable in principle, but not likely 1 to 1 . Therefore, a universal energy strategy for all regions does not exist. It is important to understand that the strategy has to adjust the specific energy situation and the peculiarities in the target region and has to integrate all participating stakeholders (government, private actors/consumers, local enterprises, organisations and associations).

Furthermore, the following aspects of advice should be considered for developing an individual energy strategy: have a multidimensional and holistic approach; base it on a long-term strategy, stakeholder commitment and political consensus; raise awareness in the population; the strategy must be financeable and realistic.

Reasonable and feasible goals on reducing energy usage should be defined in order to meet the target of wider schemes like national and European energy strategies. The energy strategies should be 
elaborated at the regional and local level, which makes a broad involvement of public and private experts and stakeholders necessary. All actors involved in producing the strategies and all potential levels and organisations for implementing them must be involved at an early stage of a project. Stable regional networks should be developed. This will only be possible through constant and transparent communication; all activities and plans need to be discussed not only in expert rounds but should be made known to a broader interested public. Participation processes need to be moderated in order to not only integrate everyone concerned at appropriate prioritisation, but also to make use of the information and input that comes from outside core groups working on the strategy. A regional energy strategy should consider the specific situation in a region.

\section{References}

Atici, K. B. \& Ulucan, A. (2011). A Multiple Criteria Energy Decision Support System. Technological and Economic Development of Economy, 17(2), 219-245. http://dx.doi.org/10.1016/j.rser.2012.10.024

Baležentis, A., Baležentis, T., \& Brauers, W. K. M. (2011). Implementation of the strategy Europe 2020 by the multi-objective evaluation method multimoora. Ekonomie a Management, 14(2), 6-21.

Byrne, J., Hughes, K., Rickerson, W., \& Kurdgelashvili, L. (2007). American policy conflict in the greenhouse: Divergent trends in federal, regional, state, and local green energy and climate change policy. Energy Policy, 35(9), 4555-4573. http://dx.doi.org/10.1016/j.enpol.2007.02.028

Busche, S. (2010). Clean Energy Policy Analyses: Analysis of the Status and Impact of Clean Energy Policies at the Local Level. Technical Report: NREL/TP-6A20-49720, Golden. USA.

Calvert, K., Pearce, J. M., \& Mabee, W. E. (2013). Toward renewable energy geo-information infrastructures: Applications of GIScience and remote sensing that build institutional capacity. Renewable and Sustainable Energy Reviews, 18, 416-429. http://dx.doi.org/10.1016/j.rser.2012.10.024

Del Río, P. (2011). Analysing future trends of renewable electricity in the EU in a low-carbon context. Renewable and Sustainable Energy Reviews, 15(5), 2520-2533. http://dx.doi.org/10.1016/j.rser.2010.12.013

Doukas, H. (2013). Modelling of linguistic variables in multicriteria energy policy support. European Journal of Operational Research, 227, 227-238. http://dx.doi.org/10.1016/j.ejor.2012.11.026

Duić, N., Guzović, Z., Kafarov, V., Klemeš, J. J., Mathiessen, B. V., \& Yan, J. (2013). Sustainable development of energy, water and environment systems. Applied Energy, 101, 3-5. http://dx.doi.org/10.1016/i.apenergy.2012.08.002

El Bassam, N., Maegaard, P., \& Schlichting, M. L. (2013). Distributed Renewable Energies for Off-Grid Communities. Distributed Renewable Energies for OffGrid Communities, 91-109.

Kaygusuz, K. (2012). Energy for sustainable development: A case of developing countries. Renewable and Sustainable Energy Reviews, 16(2), 1116-1126. http://dx.doi.org/10.1016/j.rser.2011.11.013
Lantz, M., Svensson, M., Björnsson, L., \& Börjesson, P. (2007). The prospects for an expansion of biogas systems in Sweden - Incentives, barriers and potentials. Energy Policy, 35(3), 1819-1829. http://dx.doi.org/10.1016/j.enpol.2006.05.017

Lindseth, G. (2004). The Cities for Climate Protection Campaign (CCPC) and the framing of Local Climate Policy. Local Environment, 9(4), 325-336. http://dx.doi.org/10.1080/1354983042000246252

Lutsey, N. \& Sperling, D. (2008). America's bottom-up climate change mitigation policy. Energy Policy, 36(2), 673-685. http://dx.doi.org/10.1016/j.enpol.2007.10.018

Peng, Y., Guosheng, C. \& Yancai, R. (2011). The Research on the Assessment of Sustainable Development of County Economy. Energy Procedia, 5, 921-925. http://dx.doi.org/10.1016/j.egypro.2011.03.163

Peterson, T. D., \& Rose, A. Z. (2006). Reducing conflicts between climate policy and energy policy in the US: The important role of the states. Energy Policy, 34(5), 619631. http://dx.doi.org/10.1016/j.enpol.2005.11.014

Rammel, C. \& Van Den Bergh, J. C. J. M. (2003). Evolutionary policies for sustainable development: Adaptive flexibility and risk minimising. Ecological Economics, 47(2-3), 121-133. http://dx.doi.org/10.1016/S0921-8009(03)00193-9

Sperling, K., Hvelplund, F. \& Mathiesen, B. V. (2011). Centralisation and decentralisation in strategic municipal energy planning in Denmark. Energy Policy, 39(3), 1338-1351. http://dx.doi.org/10.1016/j.enpol.2010.12.006

Štreimikienè, D. \& Mikalauskienè, A. (2007). The framework of indicators for monitoring the implementation of EU directives promoting renewable energy sources, energy efficiency and GHG mitigation. Energetika, 4(1), 50-60.

Tolón-Becerra, A., Lastra-Bravo, X., \& Botta, G. F. (2010). Methodological proposal for territorial distribution of the percentage reduction in gross inland energy consumption according to the EU energy policy strategic goal. Energy Policy, 38(11), 7093-7105. http://dx.doi.org/10.1016/j.enpol.2010.07.028

Walker, G. (2008). What are the barriers and incentives for community-owned means of energy production and use? Energy Policy, 36, 4401-4405. http://dx.doi.org/10.1016/j.enpol.2008.09.032

Zaccai, E. (2012). Over two decades in pursuit of sustainable development: Influence, transformations, limits. Environmental Development, 1(1), 79-90. http://dx.doi.org/10.1016/j.envdev.2011.11.002 


\section{Darnios energetikos strategijos - kaip galimybė Europos Sajungos regioniniam vystymuisi}

\section{Giedrius Gecevičius, Antanas Markevičius ir Mantas Marčiukaitis}

Atsinaujinančiu ištekliu ir efektyvios energetikos laboratorija, Lietuvos energetikos institutas, Kaunas, Lietuva

(gauta 2015 m. liepos mèn.; priimta spaudai 2015 m. lapkričio mèn.)

Straipsnio tikslas yra sukurti metodiką, leidžiančią igyvendinti darnios energetikos strategijas vietiniu, savivaldybės ir nacionaliniu lygiu, siekiant efektyviau diegti inovatyvias politikos priemones bei komponentus. Šis tikslas atitinka Europos Sajungos regioninę politiką bei Europos Sąungos strategiją „Europa 2020“, kurią igyvendinant užtikrinama geresnè ekonominè ir socialinė aplinka bei mažinama atskirtis tarp regionų.

Tyrimas buvo atliktas remiantis Baltijos jūros regiono programos (Baltic Sea Region 20072013 programme) „Energetikos alternatyvos visuomenei“ (PEA) projekto igyvendinimo metu surinkta medžiaga. Atliktame darbe buvo taikoma darnios energetikos strategijų rengimo metodika, kurios pagrindinis bruožas yra holistinis požiūris, atsirandantis bendradarbiaujant savivaldybėms, bendruomenèms, verslui bei tyrejjams. Straipsnyje yra analizuojami pagrindiniai darnios energetikos strategijos igyvendinimo žingsniai bei pateikiamos tokios strategijos rengimo rekomendacijos.

Raktiniai žodžiai: darnus vystymasis, atsinaujinantys energijos šaltiniai, regioninès strategijos. 


\title{
Assessment of Overall SCP State of the Company: New Integrated Sustainability Index $I_{S C P}$
}

\author{
Gintė Jonkutè
}

Institute of Environmental Engineering, Kaunas University of Technology, Kaunas, Lithuania.

Corresponding author:

G. Jonkute, Institute of Environmental Engineering, Kaunas University of Technology, K. Donelaičio St. 20. Kaunas, Lithuania

E-mail: ginte.jonkute@ktu.lt

(received in April 2015; accepted in July 2015)

The encouragement of sustainable consumption and production (SCP) in order to continuously improve the well-being of present and future generations is the most important goal stated in the European Union (EU) Sustainable Development Strategy, which was renewed in 2006.

The challenge for every company on the way to SCP is not only to use appropriate methods and measures to solve their specific sustainability problems, but, first of all, to select appropriate performance indicators and implement an effective sustainability performance evaluation system. It may be useful to apply an integrated indicator as a single comparable index, reducing the number of sustainability decision-making criteria that need to be considered.

However, despite various approaches to create frameworks and methodologies for the development of integrated sustainability indicators that measure, monitor and assess the progress of an enterprise towards sustainability, there is still no comprehensive framework for integrated sustainability assessment of the overall company state on the basis of manufacturing processes, products/services as well as relationship with various stakeholders.

An algorithm is here presented in respect of this demand. This algorithm offers methodical suggestions to assess the customers' opinion about the presence of company's environmental and social sustainability activities and initiatives, to identify and select most appropriate sustainability indicators, to determine their significance according to analytic hierarchy process (AHP), and to solve the most important sustainability problems in 3 aforementioned levels by adapting most suitable tools. The final suggestions are based on the values of 3 sub-indices of a new integrated index for the overall assessment of the SCP state in the company, $I_{S C P}$.

Keywords: sustainable consumption and production (SCP), companies, sustainability performance indicators, integrated index, analytic hierarchy process (AHP).

\section{$1 \quad$ Introduction}

Sustainable Consumption and Production (SCP) was firstly put on the global policy agenda at the United Nations (UN) Conference on Environment and Development in Rio de Janeiro in 1992 (Szlezak et al., 2008) where unsustainable consumption and production patterns were recognised as the main factors influencing unsustainable world's development (Jackson, 2006; Liu et al., 2010; Szlezak et al., 2008). According to the classical definition of sustainable development (SD), the UN Commission on Sustainable Development described SCP as the consumption of products and services that are necessary to satisfy essential needs and ensure better quality of life, while reducing consumption of natural resources, emissions of toxic substances and wastes through all their life cycles with the aim to cause no threat for the demands of future generations (Norris et al., 2003; Welfens et al., 2010; Welford et al., 1998). Ten years after the Rio conference, during the World Summit on Sustainable Development (which took place in Johannesburg in 2002) transformations in SCP models were recognised as a fundamental goal on the way to SD (Jackson, 2006), since without essential changes in the production and consumption system the 
global sustainable development goal cannot be achieved (Szlezak, et al., 2008; Watson, et al., 2010).

Although consumption is the most important factor for economic growth (Abeliotis et al., 2010), it can affect the environment in many different ways (Abeliotis et al., 2010; Hansen \& Schrader, 1997; Orecchia \& Zoppoli, 2007). The current unsustainable pattern of consumption and production determines climate change, pollution, accumulation of hazardous wastes, depletion of natural resources and decline in biological diversity; it also influences an increase in global migration and differences in economic and social welfare between and within countries (Čiegis \& Zeleniūtè, 2008; Nash, 2009). Higher levels of consumption influence higher levels of production, which require larger inputs of energy and material as well as generate larger quantities of waste by-products (Kletzan et al., 2002; Orecchia \& Zoppoli, 2007).

During the last decades, initiatives in sustainable production have successfully focused on improving the resource efficiency in manufacturing systems (Jackson, 2005; Sikdar, 2011). However, despite the improvement in results of environmental practices of many individual producers, an increase in the amount of general consumption often exceeds the achieved progress (the so-called rebound effect) (Staniškis \& Stoškus, 2008; Staniškis et al., 2012; Stø et al., 2006). It is becoming obvious that technological approaches are not enough to realise the goal of SD without critical assessment of human choices (Hertwich, 2005; Jackson, 2005; Dahl, 2012). Thus, in order to determine the most suitable direction for the actions towards SCP, it is essential to analyse the relation between consumption and production systematically, considering not only producers and consumers, but also all the other interested groups in the SCP system, such as government, non-governmental organisations (NGOs), shareholders, suppliers, academic community and media, etc. (Gold et al., 2010).

Integration of sustainability thinking and practice into an organisational structure requires a system approach with an appropriate management framework. However, there is no generic 'off-theshelf' management framework for every organisation that could enable a systematic and structured approach to manage their corporate sustainability (Azapagic, 2003). Thus, the challenge for every company on the way to SCP is to use appropriate methods and measures to solve their specific sustainability problems (Carson, 2007). To manage integration of the tools and to ensure effective information flows for decision-making, selection of appropriate performance indicators and implementation of an effective sustainability performance evaluation system are needed (Staniškis and Arbačiauskas, 2009). It may be useful to use an integrated indicator as a single comparable index, linking many sustainability issues and, thus, reducing the number of decision-making criteria that need to be considered (Azapagic, 2003; Krajnc \& Glavič, 2005a; Singh et al., 2007, 2009, 2012).

Currently, there are various approaches to create frameworks and methodologies for the development of integrated sustainability indicators that measure, monitor and assess the progress of an enterprise towards sustainability. However, despite these attempts, there is still no comprehensive framework for integrated sustainability assessment of the overall company state on the basis of manufacturing processes, products/services as well as relationship with various stakeholders.

In respect of this demand, the algorithm for integrated sustainability assessment of the overall company state, which can help to solve the most significant problems in 3 levels - manufacturing processes/company's activities, products/services as well as relationship with various stakeholders - is presented. This framework proposes the assessment of current sustainability conditions of the company based on sub-indices of the composite index $I_{\mathrm{SCP}}$ for sustainability evaluation and, according to them, can help to select and introduce the most suitable SD tools for a particular enterprise to achieve its environmental and social performance goals.

\section{The algorithm for evaluation of the impact of company's sustainability performance}

There are a number of frameworks of sustainability assessment that evaluate the performance of companies (Singh et al., 2009, 2012) as well as dozens of indicators that have been suggested for use in determining improvements made to processes, manufacturing sites or enterprises (Krajnc \& Glavič, 2005, 2005a). However, only some of these measures have an integral approach taking into account environmental, economic and social aspects (sometimes the fourth dimension, namely institutional, introduced by the UN approach (Labuschagne et al., 2005) is included as well), not focusing on only one of them (Singh et al., 2009, 2012). A detailed discussion on sustainability indicators can be found in the publications of Azapagic \& Perdan (2000), Veleva \& Ellenbecker (2001), Azapagic (2003), Krajnc \& Glavič (2005), Singh et al. (2009, 2012), Moldan et al. (2012) and others.

Sustainability reports usually introduce a set of SD indicators that can be used to measure sustainability performance of the company (Azapagic, 2003). Whilst it is important to identify and quantify all the relevant indicators, it may sometimes be difficult to make business decisions based on a large number of performance criteria (Azapagic, 2003; Krajnc \& Glavič, 2005, 2005a; Singh et al., 2007). To help decision makers in this respect, it could be beneficial to use integrated indicators that link many sustainability issues and hereby reduce the number of decision-making criteria (Azapagic, 2003; Krajnc \& Glavič, 2005a; Singh et al., 2007, 2009, 2012). Thus, composite indicators, being an innovative approach to evaluate sustainable performance, are increasingly recognised as a useful tool for policy making as well as public participation in sustainability discussion 
(Krajnc \& Glavič, 2005; Singh et al., 2007, 2009, 2012).

Currently, there are various approaches to create frameworks and methodologies for the development of integrated sustainability indices that measure, monitor and assess the progress of an enterprise towards sustainability. Significant examples are presented in the publications of Azapagic (2003), Krajnc \& Glavič (2005, 2005a); Singh et al. (2007, 2009, 2012), Kang et al. (2010); Kinderytè et al. (2010) and Kinderyte $(2010,2011,2013)$ as well as Laurinkevičiūtè \& Stasiškienè (2010). Despite these attempts and urgent demand to find better performance indicators (Dahl, 2012), there is still no comprehensive framework for integrated sustainability assessment of the overall company state on the basis of manufacturing processes, products/services as well as relationship with various stakeholders.
In respect of this demand, the algorithm (see Figure 1) was developed offering methodical suggestions to assess the customers' opinion about the presence of company's environmental and social sustainability activities and initiatives; to identify and select the most appropriate sustainability indicators; to determine their significance according to analytic hierarchy process (AHP); and to solve the most important sustainability problems in 3 levels manufacturing processes/company's activities, products/services and stakeholders by adapting the most suitable sustainable development tools. The final suggestions of the algorithm are based on the values of the 3 sub-indices of a new integrated index for the overall assessment of the SCP state in the company, $I_{S C P}$.

The steps of the algorithm for integrated sustainability assessment of the overall company state based on the calculation of $I_{\mathrm{SCP}}$ are explained below.

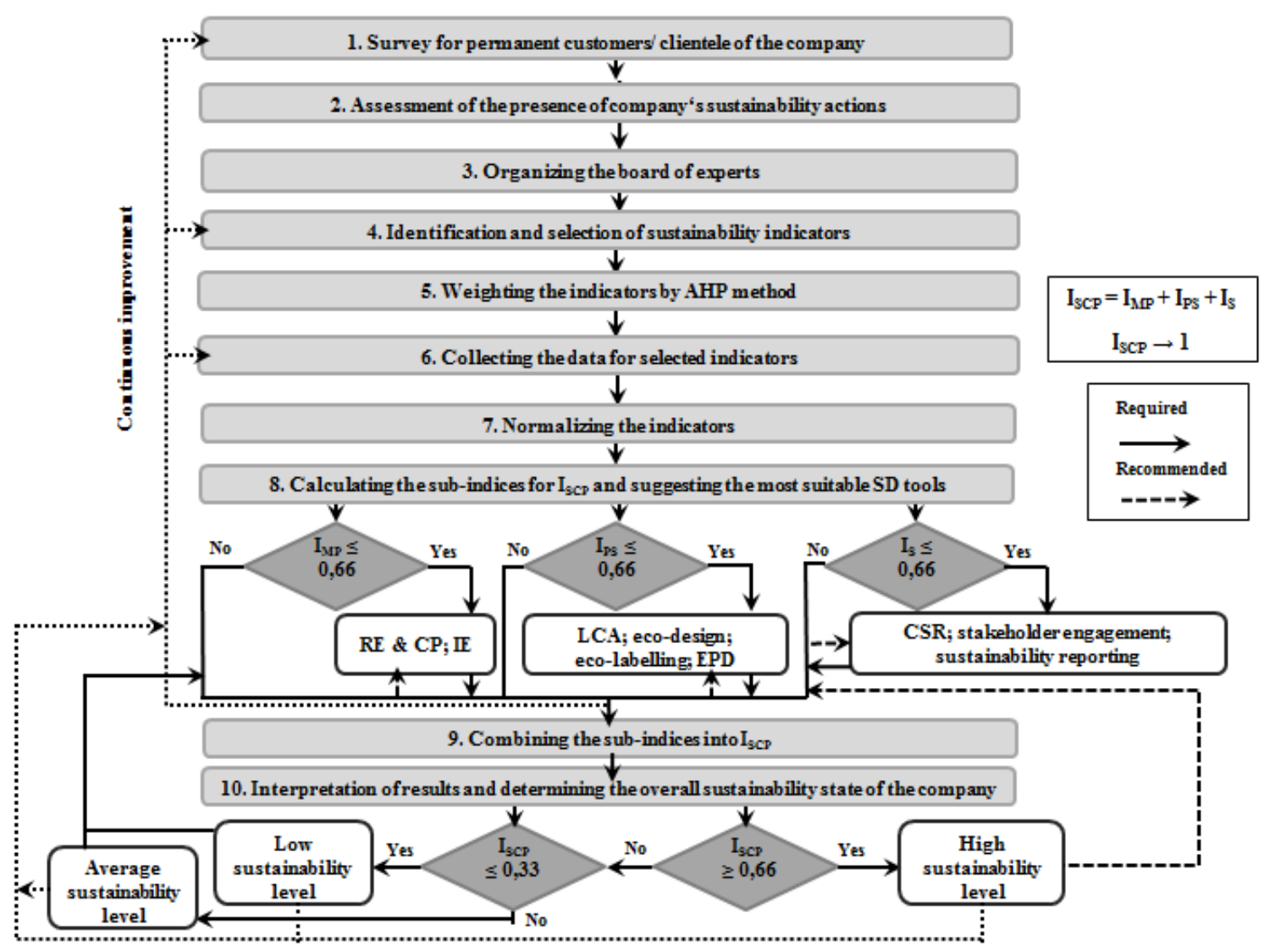

Figure 1. The algorithm for integrated sustainability assessment of the overall company state on the basis of manufacturing processes/company's activities, products/services as well as relationship with various stakeholders

\subsection{Survey for permanent customers/clientele of the company}

The aim of the survey is to assess the opinion of company's customers about the presence of environmental and social sustainability activities and initiatives of the enterprise in every of the 3 levels as well as to express their overall satisfaction regarding company's performance. The respondents are asked to evaluate each of 25 presented statements, related to manufacturing processes/company's activities (4 statements), products/services (4 statements) and collaboration with stakeholders (10 statements) as well as their general satisfaction regarding company's sustainability activities (7 statements) (Table 1). The formulation of some of these clauses is partially based on the statements for the green customers' satisfaction analysis proposed by Chen (2010). They are asked to rate these statements on a 5-point Likert scale, assessing the level of their (non)acceptance of each item (where 1 = strongly disagree, $5=$ strongly agree). The results of the survey are compiled and the mean values of each statement as well as each set of statements are determined. 


\subsection{Assessment of the presence of company's sustainability actions}

The presence of company's sustainability actions related to manufacturing processes/company's activities, products/services and stakeholders is based on the values of the coefficients $K_{j}\left(K_{M P}, K_{P S}\right.$ and $\left.K_{S}\right)$. These coefficients are evaluated recalculating the mean values of customers' answers in every of the 3 prime aforementioned sets of the statements to the parts of percentage (where $1 \rightarrow 0 ; 2 \rightarrow 0.25 ; 3 \rightarrow 0.5$; $4 \rightarrow 0.75$ and $5 \rightarrow 1$ ). The index of general green customers' satisfaction $I_{G C S}$ is calculated similarly to the coefficients $K_{j}$, assessing the average results of the respondents' answers from the fourth set of statements.

Table 1. Sets of statements in the customers' survey related to manufacturing processes/company's activities, products/services, collaboration with stakeholders as well as general customers' satisfaction for company's sustainability activities.

\begin{tabular}{|c|c|}
\hline \multicolumn{2}{|r|}{ Statements related to manufacturing processes/company's activities } \\
\hline 1. & $\begin{array}{l}\text { Company implements and uses efficient and modern technologies, applies preventive management and organisational } \\
\text { measures }\end{array}$ \\
\hline 2. & $\begin{array}{l}\text { Manufacturing processes/company's activities correspond to or even exceed the environmental requirements and } \\
\text { principles of social responsibility }\end{array}$ \\
\hline 3. & Company efficiently and economically uses all the materials, energy, water and other resources \\
\hline 4. & Company suitably manages, reuses and recycles all its wastes \\
\hline \multicolumn{2}{|r|}{ Statements related to company's products/services } \\
\hline 1. & Company creates and designs products/services considering various environmental and social criteria and standards \\
\hline 2. & $\begin{array}{l}\text { Company's products/services correspond to or even exceed the environmental requirements and principles of social } \\
\text { responsibility }\end{array}$ \\
\hline 3. & Company increases the offer of environmentally friendly products and services in the market \\
\hline 4. & $\begin{array}{l}\text { Company proposes clear, easy understandable and comparable information about the characteristics and impacts of its } \\
\text { products/services }\end{array}$ \\
\hline \multicolumn{2}{|r|}{ Statements related to company's cooperation with its stakeholders } \\
\hline 1. & $\begin{array}{l}\text { Company promotes sustainability initiatives between its employees, raises their consciousness and motivation, organises } \\
\text { special trainings }\end{array}$ \\
\hline 2. & Company incorporates sustainability criteria for products and services in its purchasing procedures (green purchasing) \\
\hline 3. & Company proposes requirements for its suppliers to correspond to the particular environmental and social criteria \\
\hline 4. & $\begin{array}{l}\text { Company cooperates with other enterprises, learns from their sustainability initiatives, intercepts examples of best } \\
\text { practices and motivates them to accept both environmentally and socially sustainable decisions }\end{array}$ \\
\hline 5. & $\begin{array}{l}\text { Company enhances environmental consciousness of its customers/consumers, promotes sustainable consumption, } \\
\text { educates them about environment protection, eco-labelling and other sustainability topics }\end{array}$ \\
\hline 6. & $\begin{array}{l}\text { Company engages in public environmental initiatives and campaigns, participates in various events for society } \\
\text { sustainability promotion }\end{array}$ \\
\hline 7. & $\begin{array}{l}\text { Company closely cooperates with NGOs that promote sustainability initiatives, e.g. green movement organisations, } \\
\text { associations for environment protection, etc. }\end{array}$ \\
\hline 8. & $\begin{array}{l}\text { Company cooperates with educational and science institutions that support the increase in sustainability knowledge and } \\
\text { perception as well as help to apply and implement technological and other innovations, etc. }\end{array}$ \\
\hline 9. & $\begin{array}{l}\text { Company cooperates with media, publicising its environmentally and socially sustainable products/services as well as } \\
\text { motivating and educating society to consume sustainably, etc. }\end{array}$ \\
\hline 10. & $\begin{array}{l}\text { Company periodically represents the information about its environmental and social practices through publicly available } \\
\text { reports }\end{array}$ \\
\hline \multicolumn{2}{|r|}{$\begin{array}{l}\text { Statements related to general consumer satisfaction regarding environmental and social sustainability of company's } \\
\text { activities and products/services }\end{array}$} \\
\hline 1. & Company contributes to the realisation of SCP goals through its products/services \\
\hline 2. & The name/brand of the company associates with environmental sustainability and social responsibility \\
\hline 3. & $\begin{array}{l}\text { I assess the company regarding its environmental and social practices better than other enterprises that produce } \\
\text { analogous products and/or render analogous services }\end{array}$ \\
\hline 4. & Company sufficiently corresponds to the requirements and expectations of environmentally responsible consumers \\
\hline 5. & I believe that I contribute to the realisation of SCP goals when I choose products/services of this company \\
\hline 6. & I will buy products/services of this company in the future \\
\hline 7. & I recommend products/services of this company to my family members, friends and acquaintances, etc. \\
\hline
\end{tabular}




\subsection{Organising the board of experts}

As different stakeholders of the company have different priorities, needs and expectations, they could share the decision-making power with corporate management (Madsen \& Ulhøi, 2001) in the following steps of identification, selection and weighting of sustainability indicators. Ideally, the board of experts should include representatives from all the internal and external stakeholder groups of the company.

\subsection{Identification and selection of sustainability indicators}

For the assessment of sustainability, a number of indicators exist, which are used to evaluate organisation's progress towards sustainability (Krajnc \& Glavič, 2005a). However, every indicator is not relevant for each branch of the industry and it may not be useful to put all these indicators into the proposed framework (Singh et al., 2007). To make sustainability performance evaluation meaningful in terms of better enterprise management, the company has to develop its own individual set of indicators that reflect its profile and needs (Labuschagne et al., 2005; Staniškis \& Arbačiauskas, 2009). The set of indicators can be identified in a number of ways, including theory findings, empirical analysis, consultations with stakeholders, etc. (Azapagic, 2003; Singh et al., 2007).

As indicators guide management control and strategic planning, they should be defined with care and should take the specific interests of the company into account (Krajnc \& Glavič, 2005). Azapagic (2003) suggests that indicators should be quantitative whenever possible; however, for societal aspects of sustainability, qualitative descriptions may be more appropriate (Krajnc \& Glavič, 2005a).

Decision-makers of companies have different views and are interested in different indicators; thus, they should be selected by taking into account appropriate communities of interest (Singh et al., 2009, 2012). This task is realised through the board of experts, including representatives from all stakeholder groups of the company. In this step, quantitative and qualitative sustainability indicators related to manufacturing processes, products/services and collaboration with stakeholders are identified. It is recommended to use the list of performance indicators from the Global Reporting Initiative (GRI) guidelines as a primary set of indicators to perform this identification. In order to ascertain the most relevant indicators for a particular company, every individual from the aforementioned board of experts is asked to rate each of them on a 5-point Likert scale. The results are compiled and the mean value of each indicator is determined. The best-rated indicators for each level are selected for further weighting procedure in step 5 .

\subsection{Weighting the indicators by AHP method}

To determine the weights of indicators, evaluators are often confronted with a lack of data. Therefore, a pairwise comparison technique is used in order to derive relative weights of each indicator practically. The pairwise comparison technique is based on the method developed by operation research pioneer Saaty (1980) and is called the Analytic Hierarchy Process (AHP) (Krajnc \& Glavič, 2005a). The AHP has been accepted as a leading multiattribute decision model both by practitioners and academics (Krajnc \& Glavič, 2005; Singh et al., 2007) and has been widely applied in many areas including SD (Singh et al., 2007). The AHP method was already applied to the development of composite sustainability performance indices in the earlier publications of Krajnc \& Glavič (2005, 2005a), Singh et al. (2007) as well as Laurinkevičiūtė and Stasiškienè (2010).

Pairwise comparisons between each pair of indicators are made by posing the question which of them is more important with respect to the ultimate SCP goals of the company, namely resources and energy savings as well as an increase in consumers' acceptance and satisfaction. The intensity of preference is expressed on a factor scale from 1 to 9 (where 1 = equal indicators, $9=1$ indicator is 9 times the importance of the other). The same process of comparison is repeated for each column of the matrix, making independent judgments over each pair of indicators (Krajnc \& Glavič, 2005, 2005a; Singh et al., 2007). Saaty (1996) has shown that solving the right eigenvector of the matrix will provide an excellent estimate of the relative weights $W_{\mathrm{ji}}$ of the indicators evaluating their priority level (Singh et al., 2007).

\subsection{Collecting the data for selected indicators}

This step of the algorithm involves collection of reliable, high quality quantitative and qualitative data for previously selected indicators, reflecting the performance of the company for the period of 1 year or 3 years. As Kinderyte $(2010,2011,2013)$ has suggested, the evaluation of the company's sustainability according to qualitative indicators is built on a 3-level scale: worst evaluation - 0 ; medium evaluation -0.5 and best evaluation -1 .

\subsection{Normalising the indicators}

The main problem of aggregating a set of indicators into an integrated one is the fact that they may be expressed in different units. One way to solve this problem could be to normalise each indicator (Kinderyte, 2010, 2011; Krajnc \& Glavič, 2005, 2005a). Many methods for normalisation of the indicators are reported in the literature and the selection of an appropriate method depends on the data and the analyst (Singh et al., 2009, 2012).

The normalisation of all the indicators in the presented algorithm is recommended to be made by applying Min-Max (Kinderyte, 2010, 2011, 2013; Krajnc \& Glavič, 2005, 2005a) or Z-score (Singh et 
al., 2007) methods using formulas (Equations 1, 2, or 3):

$$
\begin{gathered}
I_{N, i j t}{ }^{+}=\frac{I_{A, i j t}{ }^{+}-I_{\text {min }, j t}{ }^{+}}{I_{\text {max }, j t^{+}}{ }^{+} I_{\text {min }, j t}{ }^{+}} \\
I_{N, i j t}{ }^{-}=1-\frac{I_{A, i j t}{ }^{-}-I_{\text {min }, j t}{ }^{-}}{I_{\text {max }, j t^{-}}-I_{\text {min }, j t}{ }^{-}}
\end{gathered}
$$

where $I_{A, i j t}{ }^{+} / I_{A, i j t}{ }^{-}$- indicator whose increasing value has a positive/negative impact on sustainability; $I_{\text {min }, j t}{ }^{+} / I_{\text {min }, j t}{ }^{-}$- indicator with minimum value and positive/negative impact on sustainability; $I_{\max , j t}{ }^{+} /$ $I_{\max , j t^{-}}{ }^{-}$indicator with maximum value and positive/negative impact on sustainability; $I_{N, i j t}{ }^{+} /$ $I_{N, i j t}{ }^{-}$- normalised indicator whose increasing value has a positive/negative impact on sustainability; $i-$ sustainable development indicator; $j$ - group of sustainable development indicators: manufacturing processes/company's activities, products/services and collaboration with stakeholders; $t$ - time in years.

$$
I_{N, i j t}=\frac{\left(I_{A, i j t}-I_{\text {avg }, j t}\right)}{S D}
$$

where $I_{a v g, j t}$ - average value of indicator; SD standard deviation of indicator.

Moreover, in order to minimise the sensitivity of the Min-Max normalisation method, the following normalisation conditions, suggested by Kinderyte (2013), were defined (Equations $4-8$ ):

1. If an indicator whose increasing value has a negative impact has constant minimum values, then it is assumed as the best possible value and by normalisation 1 is assigned:

$$
\text { if } I_{A, i j t}{ }^{-}=I_{\text {min }}=\text { const, then } I_{N, i j t}{ }^{-}=1 \text {. }
$$

2. If an indicator whose increasing value has a positive impact has constant maximum values, then it is assumed as the best possible value and by normalisation 1 is assigned:

$$
\text { if } I_{A, i j t}{ }^{\mp}=I_{\text {max }}=\text { const, then } I_{N, i j t}{ }^{+}=1 \text {. }
$$

3. If an indicator whose increasing value has a positive impact is expressed in percent, then by normalisation: $I_{N, i j t}{ }^{+}=I_{A, i j t}{ }^{+} / 100$.

4. If an indicator has a constant but not possible maximum or minimum value, then by normalisation 0.5 is assigned:

$$
\text { if } I_{A, i j t}=\text { const, then } I_{N, i j t}=0.5 \text {. }
$$

5. If values of indicators are not constant, but the difference is very small, then by normalisation 0.5 is assigned:

$$
\text { if } \frac{I_{A, i j t}}{I_{A, i j t+1}} \geq 0.99 \text {, then } I_{N, i j t}=0.5 \text {. }
$$

\section{$2.8 \quad$ Calculating the sub-indices for $I_{S C P}$ and} suggesting the most suitable SD tools

The sub-indices $I_{S, j t}$ for all the 3 levels manufacturing processes/company's activities $\left(I_{M P}\right)$, products/services $\left(I_{P S}\right)$ and stakeholders $\left(I_{S}\right)$ - are evaluated according to the formula (Equation 9) (Kinderytè, 2011, 2013; Krajnc \& Glavič, 2005, 2005a; Singh et al., 2007), considering the weights of every indicator $W_{j i}$ (Equation 10), which were generated during an expert weighting procedure as well as coefficients $K_{j}$ from the consumers' survey:

$$
\begin{gathered}
I_{S, j t}=\left(\sum_{j i t}^{n} W_{j i} I_{N, i j t}{ }^{+}+\sum_{j i t}^{n} W_{j i} I_{N, i j t}{ }^{-}\right) \times K_{j} \\
\sum_{j i}^{n} W_{j i}=1, W_{j i} \geq 0
\end{gathered}
$$

Each of these sub-indices shows the tendency of company's sustainability development regarding the SCP in one of the corresponding levels. The minimal value of a particular sub-index indicates that the related level is the weakest in the whole system; thus, the condition of it should be improved by applying suitable tools and measures. If the lowest value is recorded at the level of manufacturing processes/company's activities $\left(I_{M P} \leq 0.66\right)$, the model suggests realising resource efficiency and cleaner production (RE \& $\mathrm{CP}$ ) as well as industrial ecology (IE) opportunities. Poorest conditions regarding the characteristics of products and services $\left(I_{P S} \leq 0.66\right)$ can be fixed by applying life cycle assessment (LCA) based measures, such as eco-design, eco-labelling and environmental product declarations (EPD). If the weakest area of the enterprise seems to be relations with stakeholders $\left(I_{S} \leq 0.66\right)$, corporate social responsibility (CSR) according to an international standard ISO 26000, various stakeholder engagement initiatives as well as improvements in sustainability reporting should be reconsidered.

\subsection{Combining the sub-indices into $I_{S C P}$}

Finally, the calculated sustainability sub-indices $I_{S, j t}$ are combined into an integrated index for the assessment of the overall SCP state of the company, $I_{S C P}$, using the formula (Equation 11):

$$
I_{S C P, t}=\sum_{j t}^{n} W_{j} I_{S, j t}
$$

where $W_{j}$ denotes the factor for representing $a$ priori the weight given to group $j$ of SD indicators (manufacturing processes/company's activities, products/services and relations with stakeholders), reflecting the hierarchies and/or priorities in the opinion of decision-makers (Krajnc \& Glavič, 2005, $2005 \mathrm{a})$. In the final calculation of the $I_{S C P}$, an approach that uses estimated weights can be considered; 
however, it is recommended to use equal weights for all the sub-indices (Kinderytè, 2011, 2013; Krajnc \& Glavič, 2005, 2005a).

\subsection{Interpretation of results and determination of the overall sustainability state of the company}

In general, the integrated index helps to make decisions about the overall level of enterprise's sustainability (Azapagic, 2003; Kinderytè et al., 2010) and highlight the achieved progress (Azapagic, 2003; Krajnc \& Glavič, 2005a; Singh et al., 2007). As the composite indicator integrates a large amount of information into an easily understood format for a general audience (Singh et al., 2007), it can be used to inform decision-makers and various interested parties of SD trends in the company. The higher is the value of the index, the greater is the improvement of the company towards sustainability. The same is true for sustainability sub-indices as well. For any given year, the composite index and sub-indices reveal the performance of the company in that year compared with other years (Krajnc \& Glavič, 2005a). Also, if analogous methodology and similar indicators for inde $x$ calculation were applied to different companies, it would be possible to compare and rank them according to the current sustainability state (Krajnc \& Glavič, 2005, 2005a).

The integrated index $I_{S C P}$ that is proposed in the algorithm can help to disclose the overall SCP state of the company. If this index is lower than the value 0.33 , the particular company can be named as unsustainable and must urgently rethink the whole business strategy, implementing all the possible actions and measures in all the system levels with the purpose of improving its overall sustainability condition. If the calculated value lies between 0.33 and 0.66 , the enterprise shows the average level of the sustainability state regarding the implementation of SCP practices. In this case, it is strongly recommended to implement suitable measures and tools, especially in those particular levels, which show the worst results according to the values of sub-indices. And finally, if $I_{S C P}$ exceeds the critical value of 0.66 , it can be stated that the enterprise is on the right way to become comprehensively sustainable and its overall sustainability is as high as the value of $I_{S C P}$ is closer to 1 . However, even on a high level of sustainability, the company can still improve its current sustainability state by implementing additional measures and tools and, thus, exploiting all its sustainability potential.

Furthermore, the value of the green customers' satisfaction index $I_{G C S}$, determined from the average results of customers' answers in step 2, can also be helpful as an additional parameter to appreciate purchasers' general satisfaction regarding environmental and social sustainability of company's activities and products/services. Analogous to the integrated index $I_{S C P}$, the general satisfaction of sustainably engaged customers is as high as the value of $I_{G C S}$ is closer to 1 .

\subsection{Periodical review of customers' opinion and periodical assessment of company's sustainability state}

Periodical review of the customers' opinion and periodical assessment of the company's sustainability state compose a very important part of the algorithm that guarantees continuous improvement of the enterprise's sustainability state. These assessments could help to estimate the results of sustainability enhancement concerning newly implemented measures and to observe changes in the customers' opinion. Periodical review and assessment can be realised in 3 levels - by applying the algorithm from the very beginning or by performing the inner evaluation selecting new sustainability indicators or barely collecting data for the indicators that have been already chosen to estimate the changes in 3 levels of company's activities.

\section{Conclusions and recommendations}

The presented algorithm can help to assess current sustainability conditions of the company and, according to them, select and introduce the most suitable tools to achieve SCP goals. This algorithm offers methodical suggestions to assess the customers' opinion about the presence of company's environmental and social sustainability activities and initiatives; to identify and select most appropriate sustainability indicators; to determine their significance according to analytic hierarchy process (AHP); and to solve the most important sustainability problems in 3 levels - manufacturing processes/company's activities, products/services and stakeholders - by adapting the most suitable tools. These final suggestions were based on the values of the 3 sub-indices of a new integrated index for the overall assessment of the SCP state in the company, $I_{S C P}$. Moreover, a simple additional parameter to appreciate customers' general satisfaction regarding environmental and social sustainability of company's activities and products/services - the green customers' satisfaction index $I_{G C S}$ - was also introduced.

This framework is created as a guidance to apply a theretofore designed SURESCOM (SUstainable and RESponsible COMpany) model (Jonkutè and Staniškis, in press) based on a classical closed-loop cycle scheme for an integrated management system and suggests a plan for consistent integration of SCP principles in organisation's practices; it can, therefore, be easily incorporated into a common management system of any enterprise.

As the subjected algorithm is still theoretical, there is an urgent necessity to verify its real potential in particular enterprises. The verification procedure performed in different sectors, including both manufacturing and service companies, could disclose all the opportunities of this framework. 


\section{References}

Abeliotis, K., Koniari, C., \& Sardianou, E. (2010). The profile of the green consumer in Greece. International Journal of Consumer Studies 34, 153-160. http://dx.doi.org/10.1111/j.1470-6431.2009.00833.x

Azapagic, A. \& Perdan, S. (2000). Indicators of sustainable development for industry: a general framework. Chemical Engineering Research and Design 78, 243261. http://dx.doi.org/10.1205/095758200530763

Azapagic, A. (2003). Systems approach to corporate sustainability. A general management framework. Chemical Engineering Research and Design 81, 303316.

Carson, N. (2007). A business primer. Sustainable consumption and production, pp. 4-23, Cambridge, UK: University of Cambridge programme for industry.

Chen, Y.-S. (2010). The Drivers of Green Brand Equity: Green Brand Image, Green Satisfaction, and Green Trust. Journal of Business Ethics 93, 307-319. http://dx.doi.org/10.1007/s10551-009-0223-9

Čiegis, R. \& Zeleniūté, R. (2008). Ekonomikos plètra darnaus vystymosi aspektu [Sustainable development aspects in economic development]. Taikomoji ekonomika: sisteminiai tyrimai 2/1, 37-54.

Dahl, A. L. (2012). Achievements and gaps in indicators for sustainability. Ecological Indicators 17, 14-19. http://dx.doi.org/10.1016/j.ecolind.2011.04.032

Gold, S., Seuring, S., \& Beske, P. (2010). Sustainable supply chain management and inter-organizational resources: a literature review. Corporate Social Responsibility and Environmental Management 17, 230-245.

Hansen, U. \& Schrader, U. (1997). A modern model of consumption for a sustainable society. The Journal of Consumer Policy 20, 443-468. http://dx.doi.org/10.1023/A:1006842517219

Hertwich, E. G. (2005). Life cycle approaches to sustainable consumption: a critical review. Environmental Science \& Technology 39(13), 4673-4684. http://dx.doi.org/10.1021/es0497375

Jackson T. (2005). Live better by consuming less? Is there a "double dividend" in sustainable consumption? Journal of Industrial Ecology 9(1-2), 19-36.

Jackson, T. (2006). Readings in sustainable consumption. Earthscan, pp. 1-23.

Jonkutè, G. \& Staniškis, J. K. (in press) Realizing SCP in the companies: the SURESCOM model. Journal of Cleaner Production. Preprint, submitted March 30, 2015.

Kang, Y., Ryu, M.-H., \& Kim, S. (2010). Exploring sustainability management for telecommunications services: A case study of two Korean companies. Journal of World Business 45, 415-421. http://dx.doi.org/10.1016/j.jwb.2009.08.003

Kinderyte, L. (2010). Methodology of sustainability indicators determination for enterprise assessment. Environmental Research, Engineering and Management 2(52), 25-31.

Kinderyte, L., Čiegis, R., \& Staniškis, J. K. (2010). Assessment of enterprise performance for efficient sustainability. Transformations in Business \& Economics 9, 3(21), 104-118.

Kinderyte, L. (2011). Sustainability assessment of enterprises in printing industry. Environmental Research, Engineering and Management 4(58), 59-64. http://dx.doi.org/10.5755/j01.erem.58.4.674

Kinderyte, L. (2013). Model of the system for enterprise sustainability assessment. Summary of doctoral dissertation, pp. 5-25, Kaunas, Lithuania: Technologija.
Kletzan, D., Köppl, A., Kratena, K., Schleicher, S., \& Wüger, M. (2002). Modelling sustainable consumption. From theoretical concepts to policy guidelines. Empirica $29,131-144$. http://dx.doi.org/10.1023/A:1015696710335

Krajnc, D. \& Glavič, P. (2005). A model for integrated assessment of sustainable development. Resources, Conservation and Recycling 43, 189-208. http://dx.doi.org/10.1016/S0921-3449(04)00120-X

Krajnc, D. \& Glavič, P. (2005a). How to compare companies on relevant dimensions of sustainability. Ecological Economics 55, 551-563. http://dx.doi.org/10.1016/j.ecolecon.2004.12.011

Labuschagne, C., Brent, A. C., \& van Erck, R. P. G. (2005). Assessing the sustainability performances of industries. Journal of Cleaner Production 13, 373-385. http://dx.doi.org/10.1016/j.jclepro.2003.10.007

Laurinkevičiūtè, A. \& Stasiškienè, Ž. (2010) Sustainable development decision-making model for small and medium enterprises. Environmental Research, Engineering and Management 2(52), 14-24.

Liu, J., Wang, R., Yang, J., \& Shi Y. (2010). The relationship between consumption and production system and its implications for sustainable development of China. Ecological Complexity 7, 212-216. http://dx.doi.org/10.1016/j.ecocom.2010.02.003

Madsen, H. \& Ulhøi, J. P. (2001) Integrating environmental and stakeholder management. Business Strategy and the Environment 10, 77-88. http://dx.doi.org/10.1002/bse.279

Moldan, B., Janouškova, S., \& Hak, T. (2012) How to understand and measure environmental sustainability: indicators and targets. Ecological Indicators 17, 4-13. http://dx.doi.org/10.1016/j.ecolind.2011.04.033

Nash, H. A. (2009). The European Commission's sustainable consumption and production and sustainable industrial policy action plan. Journal of Cleaner Production 17, 496-498. http://dx.doi.org/10.1016/j.jclepro.2008.08.020

Norris, G. A. (2003). Revisions to LCA needed to address sustainable consumption. In: Report of the 1st International Workshop on Sustainable Consumption, Arcadia Ichigaya, Tokyo, Japan, 19-20 March 2003, pp. 1-13.

Orecchia, C. \& Zoppoli, P. (2007). Consumerism and environment: does consumption behaviour affect environmental quality? In: CEIS Working Paper No. 261.

Saaty, T. L. (1980). The Analytic Hierarchy Process: planning, priority setting, resource allocation, New York, USA: McGraw-Hill.

Saaty, T. L. (1996). Multi-criteria decision making. The Analytic Hierarchy Process, Pittsburgh, USA: University of Pittsburgh Press.

Sikdar S.K. (2011) Analysis of systems for sustainability and decision making. In: Book of abstracts of the 2nd International Conference SCP: how to make it possible, Kaunas, Lithuania, 29-30 September 2011, p. 18.

Singh, R. K., Murty, H. R., Gupta, S. K., \& Dikshit, A. K. (2007). Development of composite sustainability performance index for steel industry. Ecological Indicators 7, 565-588. http://dx.doi.org/10.1016/j.ecolind.2006.06.004

Singh, R. K., Murty, H. R., Gupta, S. K., \& Dikshit, A. K. (2009). An overview of sustainability assessment methodologies. Ecological Indicators 9, 189-212. http://dx.doi.org/10.1016/j.ecolind.2008.05.011

Singh, R. K., Murty, H. R., Gupta, S. K., \& Dikshit, A. K. (2012). An overview of sustainability assessment methodologies. Ecological Indicators 15, 281-299. 
http://dx.doi.org/10.1016/j.ecolind.2011.01.007

Staniškis, J. K. \& Stoškus, L. (2008). Recommendations for putting sustainable consumption and production into practice in Lithuania. Results of the conference "Time for Action - Towards Sustainable Consumption and Production in Europe". Environmental Research, Engineering and Management 3(45), 3-4.

Staniškis, J. K. \& Arbačiauskas, V. (2009). Modelling sustainable management process on enterprise level. In: Proceedings of 5th International Vilnius Conference, EURO Mini Conference KORSD-2009, Vilnius Gediminas Technical University, Vilnius, Lithuania, 30 September - 3 October 2009.

Staniškis, J. K., Arbačiauskas, V., \& Varžinskas, V. (2012). Sustainable consumption and production as a system: experience in Lithuania. Clean Technologies and Environmental Policy 14, 1095-1105. http://dx.doi.org/10.1007/s10098-012-0509-y

Stø, E., Throne-Holst, H., Strandbakken, P., \& Vittersø G. (2006). A multi-dimensional approach to the study of consumption in modern societies and the potentials for radical sustainable changes. In: Proceedings: Changes to Sustainable Consumption of the Workshop of the SCORE! Network, Copenhagen, Denmark, 20-21 April 2006, pp. 13-20.

Szlezak, J., Reichel, A., \& Reisinger, H. (2008). National sustainable consumption and production (SCP) strategies in the EU - a comparative review of selected cases. Environmental Research, Engineering and Management 3(45), 54-60.

Veleva, V. \& Ellenbecker, M. (2001). Indicators of sustainable production: framework and methodology. Journal of Cleaner Production 9, 519-549. http://dx.doi.org/10.1016/S0959-6526(01)00010-5

Watson, D., Hansen, M. S., Lorenz, U., Szlezak, J., Mortensen, L., \& Stanners, D. (2010). A framework for indicator-based reporting on sustainable consumption and production. In: Knowledge Collaboration \& Learning for Sustainable Innovation ERSCP-EMSU conference, Delft, Netherlands, 25-29 October 2010.

Welfens, J. M, Liedtke, C., \& Nordmann, J. (2010). Sustainable consumption: between unsustainable reality and people's willingness to act. In: Knowledge Collaboration \& Learning for Sustainable Innovation ERSCP-EMSU conference, Delft, Netherlands, 25-29 October 2010.

Welford, R., Young, W., \& Ytterhus, B. (1998) Towards sustainable production and consumption: a literature review and conceptual framework for the service sector. Eco-Management and Auditing 5, 38-56. http://dx.doi.org/10.1002/(SICI)10990925(199803)5:1<38::AID-EMA78>3.0.CO;2-K 


\section{İmonès bendros darnumo būklès ịvertinimas tausojančio vartojimo ir darnios gamybos atžvilgiu: naujas sudètinis darnumo rodiklis $I_{\mathrm{SCP}}$}

\section{Gintè Jonkutè}

Aplinkos inžinerijos institutas, Kauno technologijos universitetas, Kaunas, Lietuva.

(gauta 2015 m. balandžio mèn.; priimta spaudai 2015 m. liepos mèn.)

Tausojančio vartojimo ir darnios gamybos skatinimas, siekiant nuolatos didinti esamų ir būsimų žmonijos kartų gerbūvị, yra svarbiausias tikslas, išreikštas 2006 m. atnaujintoje Europos Sajungos Darnaus vystymosi strategijoje.

Kiekviena įmonè, norėdama igyvendinti tausojančio vartojimo ir darnios gamybos tikslus, susiduria su iššūkiu ne tik naudoti tinkamus metodus ir priemones, siekiant išspręsti konkrečias darnumo problemas, bet, visų pirma, pasirinkti tinkamiausius darnumo vertinimo rodiklius ir diegti efektyvią veiklos darnumo vertinimo sistemą. İmonèms gali būti naudinga turèti vieną palyginamajj sudètinį rodiklį, sumažinantị darnumo vertinimo kriterijų, ị kuriuos reikia atsižvelgti, kiekį.

Nepaisant įvairių bandymų sukurti gaires sudètinių darnumo rodiklių, skirtų įmonès progreso darnumo link matavimui, kontrolei ir ịvertinimui, išsamių metodinių rekomendacijų įmonès bendros darnumo būklès ịvertinimui, atsižvelgiant ị jos gamybos procesus, gaminius (paslaugas) ir santykius su suinteresuotomis šalimis, vis dar nèra.

Atsižvelgiant i ši trūkumą, straipsnyje pristatomas algoritmas, teikiantis metodinius pasiūlymus, vertinant pirkèjų (klientų) nuomonę ir pasitenkinimą įmonès vykdomos veiklos aplinkosauginiu ir socialiniu darnumu; nustatant ir atrenkant įmonei tinkamiausius darnumo rodiklius; ịvertinant jų reikšmingumą, taikant analitinį hierarchijos procesą (AHP); ir sprendžiant svarbiausias problemas trijose anksčiau minètose srityse, diegiant tinkamiausias darniojo vystymosi priemones. Šie galutiniai algoritmo taikymo rezultatai pagrịsti trijų naujo sudėtinio rodiklio įmonès bendros darnumo būklès ịvertinimui tausojančio vartojimo ir darnios gamybos atžvilgiu $I_{\mathrm{SCP}}$ skaitinèmis vertèmis.

Raktiniai žodžiai: tausojantis vartojimas ir darni gamyba, imonès, darnumo vertinimo rodikliai, sudetinis rodiklis, analitinis hierarchijos procesas. 